\title{
DEPARTAMENTO DE CIÊNCIA POLÍTICA
}

FFLCH

Letalidade da ação policial e teoria interacional: análise integrada do sistema paulista de segurança pública

\author{
Emmanuel Nunes de Oliveira Jr. \\ Orientador: Prof. Dr. Leandro Piquet Carneiro
}

Texto

apresentado

$\mathrm{aO}$

Departamento de Ciência Política da Universidade de São Paulo para obtenção do título de doutorado. 


\section{Título: Letalidade da ação policial e teoria interacional: análise integrada do sistema paulista de segurança pública}

\section{RESUMO:}

A pesquisa Letalidade da ação policial e teoria interacional: análise integrada do sistema paulista de segurança pública visa dimensionar os fatores associados a letalidade policial. Dada a complexidade da ação policial, que envolve aspectos criminais, sociais e institucionais, a pesquisa propõe a formulação de um modelo teórico penológico que unifique diferentes tradições das Ciências Sociais.

O modelo teórico interacional, adotado na tese, integra em uma dimensão analítica as premissas presentes nas teorias racionalista, contextual, institucional e ecológica. Tal estratégica metodológica é necessária, porque os modelos paradigmáticos selecionam um único parâmetro analítico para correlacionar com a ação policial e essa simplificação do comportamento policial não encontra suporte na realidade. Nesse sentido, encontrar uma alternativa as preposições teóricas clássicas foi o principal objetivo desse trabalho.

Como estratégia de comprovação empírica do modelo teórico interacional foram utilizadas técnicas de regressão multivariadas, que permitem o teste simultâneo de validade das hipóteses alternativas e a verificação das interações entre os modelos teóricos e as variáveis independentes. A base empírica foi coletada junto a Comissão de Letalidade Policial da Secretaria de Segurança Pública do Estado de São Paulo. A amostra é de 1.111 casos de letalidade de não-policias registradas no Estado, entre 2001 e 2003.

Palavras-chave: polícia, letalidade, crime, teoria interacional e políticas públicas. 
Title: Lethality of police action and interaction theory: integrated analysis of São Paulo public security system

\begin{abstract}
ABSTRAC:
The objective of the research Lethality of police action and interaction theory: integrated analysis of São Paulo public security system is to understand factors connected with police lethality. As police action is a complex issue, with criminal, social and institutional aspects, the study aims to formulate a penal theoretical model able to unify different traditions of Social Sciences.

The interaction theoretical model adopted in the thesis integrates in an analytical dimension the premises presented in the rational, contextual, institutional and ecological thesis. This methodological strategy is necessary because the traditional models select only one parameter to police action. This simplification of police behavior does not find basis in social reality. The main proposal of this work was to find as alternative to classical theory propositions.

As empiric form to check strategy of interaction theory model, the author used multiple regression techniques that permit simultaneous test of alternative hypothesis validation and the verification of interaction between theoretical models and independent variables. The empiric basis was the São Paulo State Public Security Secretary of Police Lethality Committee with 1.111 lethality non-policeman cases in the State in 2001-2003.
\end{abstract}

Key words: police, lethality, crime, interaction theory and public policies. 


\section{Sumário}

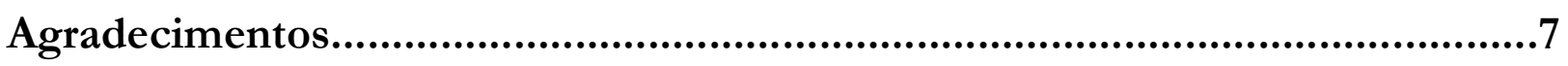

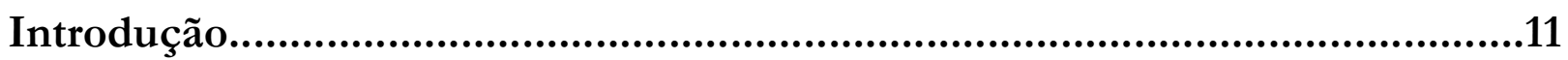

Capítulo 1

Ciências Sociais e ação policial............................................................................18

Capítulo 2

Modelo teórico interacional do comportamento policial......................................31

Operacionalização do modelo teórico..............................................................................42

\section{Capítulo 3}

Descrição e identificação das variáveis..............................................................48

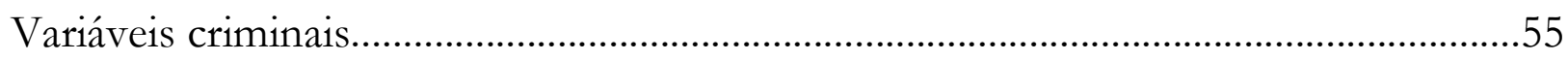

Variáveis contextuais........................................................................................................60

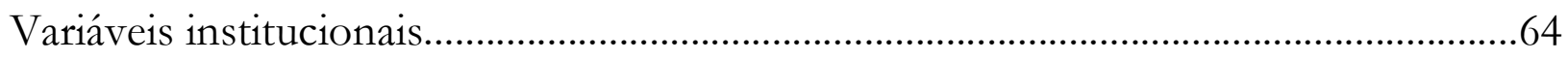

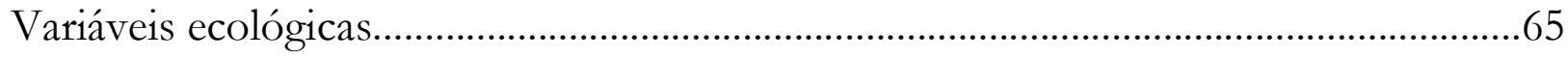

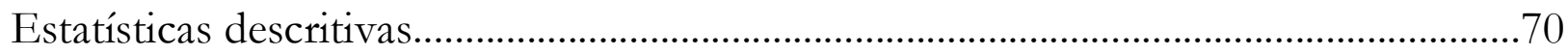

\section{Capítulo 4}

Determinantes da letalidade policial em SãoPaulo............................................73

\section{Capítulo 5}

O impacto da letalidade na opinião pública....................................................................83

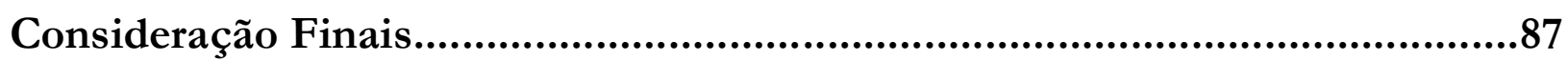

Referências Bibliográficas.....................................................................................89

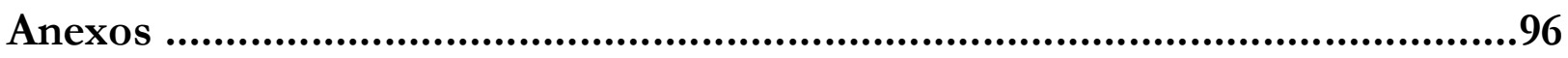

Figuras

Figura 1: representação gráfica do modelo interacional do comportamento policial..24

Figura 2: distribuição espacial dos limites geográficos dos distritos administrativos e da jurisdição das delegacias de polícia. 


\section{Mapas}

Mapa 1: distribuição espacial das mortes de não-policias em 2001.................................105

Mapa 2: distribuição espacial das mortes de não-policias em 2002...............................105

Mapa 3: distribuição espacial das mortes de não-policias em 2003.................................106

Mapa 4: distribuição espacial das 8 Comandos.................................................................106

Mapa 5: distribuição espacial dos distritos na cidade de São Paulo.................................107

\section{Gráficos}

Gráfico 1: efeito da dinâmica criminal no número de pessoas mortas pela polícia.

Gráfico 2: efeito do contexto social no número de pessoas mortas pela polícia. .34

Gráfico 3: efeito institucional no número de pessoas mortas pela polícia. .36

Gráfico 4: efeito da ecologia urbana no número de pessoas mortas pela polícia.

Gráfico 5: efeito da estrutura de interações no número de pessoas mortas pela polícia......

Gráfico 6: comparação entre as fontes de dados de não-policiais mortos em confronto com policiais nos anos pesquisados

Gráfico 7: comparação entre as fontes de dados de não-policiais mortos em confronto com policiais em serviço nos anos pesquisados. .51

Gráfico 8: relação entre o fator 1 e os valores extraídos da análise de componente principal da dinâmica criminal.

Gráfico 9: relação entre o fator 2 e os valores extraídos da análise de componente principal da dinâmica criminal. 58

Gráfico 10: relação entre o fator 3 e os valores extraídos da análise de componente principal da dinâmica criminal.

Gráfico 11: relação entre o fator 1 e os valores extraídos da análise de componente principal do contexto social. 
Gráfico 12: relação entre o fator 2 e os valores extraídos da análise de componente principal do contexto social..

Gráfico 13: relação entre o fator 3 e os valores extraídos da análise de componente principal do contexto social..

Gráfico 14: relação entre o fator 1 e os valores extraídos da análise de componente principal do desenvolvimento comunitário

Gráfico 15: relação entre o fator 2 e os valores extraídos da análise de componente principal do desenvolvimento comunitário

Gráfico 16: relação entre o fator 3 e os valores extraídos da análise de componente principal do desenvolvimento comunitário

\section{Tabelas}

Tabela 1: estatísticas descritivas.

Tabela 2: Resultado de ANOVA para as diferenças do número de letalidade de nãopoliciais nas administrações da SSP-SP, nos últimos 20 anos.

Tabela 3: Resultado de ANOVA para as diferenças do número de letalidade de nãopoliciais nas jurisdições das 8 Comandos da cidade. 65

Tabela 4: estatísticas descritivas. 71

Tabela 5: valores estimados para os coeficientes de regressão bivariada para todas as variáveis 76

Tabela 6: valores estimados para os coeficientes de regressão multivariada para todas as variáveis. .80

Tabela 7: teste para modelo aninhado 82

Tabela 8: teste para modelo não-aninhado 83

Tabela 10: valores estimados para os coeficientes de regressão multivariada sobre o efeito de letalidade na avaliação da polícia .86

Tabela 11: valores extraídos da ACP das variáveis criminais..........................................96

Tabela 12: valores extraídos da ACP das variáveis sociais...................................................97

Tabela 13: valores extraídos da ACP das variáveis ecológicas...........................................97

Tabela 14: estatísticas descritivas das variáveis criminais. .99 
Tabela 15: estatísticas descritivas das variáveis contextuais.........................................99

Tabela 16: estatísticas descritivas das variáveis ecológicas.........................................101

Tabela 17: valores estimados para os coeficientes de regressão multivariada.............103

Tabela 18: Correlações das variáveis para a amostra completa....................................104

Tabela 19: estatísticas do número de letalidade nos distritos de São Paulo.................108 


\section{Agradecimentos}

Ao professor Leandro Piquet Carneiro que começou a orientação dessa tese de doutorado antes mesmo da conclusão da graduação. Sua dedicação e atenção em todas as etapas do meu desenvolvimento intelectual dão sentido à idéia de formação intelectual. Gostaria de expressar minha gratidão por todos esses anos de convivência.

Ao $\mathrm{CNPq}$ pelo suporte financeiro para realização da pesquisa de doutorado e à CAPES que financiou o estágio de um ano na University at Buffalo (UB), State University of New York.

Ao professor Peter Saint-Jean pelo apoio inestimável para o desenvolvimento da minha pesquisa na State University of New York. Suas pesquisas sobre o impacto do desenvolvimento comunitário no controle do crime e da violência me propocionaram um contato tocqueviliano com as comunidades americanas. Sua equipe de pesquisa, da qual fiz parte durante todo período, discutiu meu trabalho e suas sugestões contribuiram muito para o desenvolvimento da tese. Agradeço a todos, principalmente, ao professor Saint-Jean.

O estágio nos Estados Unidos possibiltou, também, a participação no grupo de estudo de métodos quantitativos em Ciência Política, coordenado pela professora Michelle Benson. Meus sinceros agradencimentos a esse grupo que reunindo estudantes de cinco continentes provou que a Matemática é uma linguagem universal.

Saindo da gelada Buffalo, passei todo o verão na ensolarada Ann Arbor, fazendo o curso intensivo de metodologia quantitativa aplicado às Ciências Sociais do ICPSR (Inter-University Consortium for Political and Social Research), realizado anualmente pela Universidade de Michigan. As longas horas de estudos de métodos quantitativos foram em muito amenizadas pelas presenças de Pedro Neiva, Gabriella Piquet e do 
professor Leandro Piquet. A estada em Ann Arbor só não foi melhor porque testemunhamos a derrota da seleção brasileira de futebol.

Não poderia deixar de mencionar as discussões realizadas no seminário de pesquisa coordenado pelos professores Maria Hermínia Tavares de Almeida e professor Leandro Piquet que foram centrais no desenvolvimento da tese de doutorado. Quero deixar meus sinceros agradecimentos a todos os participantes desse grupo de pesquisa que com a prevalência de amizade e elegância, sempre cobrou rigor metodológico, clareza da argumentação e comprovação das hipóteses teóricas desse trabalho. As críticas e sugestões foram fundamentais para realização dessa tese. Para não cometer injustiças, com possíveis nomes esquecidos, agradeço o grupo todo por meio de seus coordenadores.

Agradeço à Secretaria de Segurança Pública do Estado de São Paulo na figura do coordenador da CAP Túlio Kahn, que permitiu o acesso aos dados de letalidade policial discutidos nesse trabalho. Túlio abriu, ainda, as portas para que eu participasse da Comissão de Letalidade Policial da Secretaria de Segurança Pública do Estado de São Paulo, permitindo o meu contato com material inédito sobre letalidade. Como se não bastasse tanta gentileza, Túlio se dispôs a discutir meu trabalho de doutorado no âmbito do seminário de pesquisa do departamento de Ciência Política. Meus agradecimentos a inestimável contribuição de Túlio para esse trabalho.

À SENASP - Secretaria Nacional de Segurança Pública, ligada ao Ministério da Justiça que colaborou decisivamente com esse trabalho ao conceder um prêmio para minha pesquisa. Mas do que valor financeiro, o prêmio permitiu que eu construísse a base de dados quantitativos sobre letalidade. $\mathrm{Na}$ pessoa de Marcelo Durante, expresso meus agradecimentos a toda equipe da SENASP.

À Polícia Militar e a Polícia Civil que sempre foram receptivas a minha pesquisa. O interesse demonstrado pelos policiais de São Paulo com minha pesquisa e a pronta solicitação aos meus pedidos de entrevistas e dados atestam a seriedade e o comprometimento dessas instituições com o bem coletivo e com a pesquisa 
acadêmica. Deixo meus agradecimentos às esses homens e mulheres que na sua atividade diária buscam uma sociedade melhor e menos violenta.

Agradeço a toda equipe da Secretaria de Pós-graduação de Ciência Política Márcia, Raí, Ana, Vivian e Leonardo - cuja competência só se equivale à gentileza.

Agradeço aos professores Fernando Limongi, George Avelino e Matthew Taylor pela leitura atenta e as contribuições durante o exame de qualificação.

Agradeço a toda minha família que nos momentos mais difíceis fez tudo parecer fácil.

Agradeço à minha esposa Elizabeth, cuja participação nessa tese foi tanto afetiva quanto intelectual. 


\section{Introdução}

A violência é um dos principais problemas no Estado de São Paulo. Nos últimos 23 anos, ocorreram cerca de 12.0380 homicídios dolosos, 4.8748 homicídios culposos, 103.223 tentativas de homicídio, mais de 300 mil lesões corporais, cinco mil latrocínios e, aproximadamente, 4.500 estupros. A violência contra pessoas não é o único problema do Estado, embora seja nosso pior pesadelo. No período, foram registrados mais de seis milhões de roubos e furtos, além de cerca de 2,5 milhões de ocorrências de roubo ou furto de veículo. O tráfico de substância ilícita é outra faceta do problema, foram registradas mais de 130 mil ocorrências, nas duas últimas décadas (CAP/SSP-SP, 2007).

A despeito da grave situação, o Estado está passando por intensas transformações na sua dinâmica criminal. Nos últimos cinco anos, houve uma redução de 56,81\% da taxa de homicídio. Os casos de latrocínio declinaram 53,80\% e os casos de seqüestros $59,90 \%$. O roubo e o roubo de veículo sofrem um processo de redução mais recente, a partir de 2003, registra-se queda de $11,21 \%$ dos roubos e 43,6\% dos roubos de veículos (CAP/SSP-SP, 2007). O único crime que aumentou consistentemente no período foi o tráfico de entorpecente, que praticamente dobrou em sete anos. Tráfico é indicador de atividade policial e está altamente correlacionado com o número de revistas, por exemplo. É inegável a melhoria do trabalho policial em São Paulo, mesmo quando aparentemente existe incremento de algumas atividades criminais. O número de prisão em flagrante foi intensificado, o número de armas apreendidas tem se mantido constante e os inquéritos instaurados tem aumentado progressivamente.

Mas se é patente a melhoria do serviço público de segurança, uma questão continua a ser um desafio social, político, teórico e ético. $\mathrm{O}$ número de pessoas mortas pela polícia em São Paulo ainda não acompanhou a mudança do ambiente social e institucional. As forças policiais no Estado foram responsáveis por 12.640 
pessoas mortas em confrontos de segurança pública no Estado. Somente na cidade de São Paulo, segundo as estatísticas da Secretaria de Segurança Pública do Estado de São Paulo, 3.130 pessoas foram mortas em confronto entre policiais e não-policiais. Desses, 2.905 eram não-policiais e 225 eram policiais civis e militares, totalizando, praticamente, uma pessoa morta em confronto de segurança pública por dia. Enquanto o homicídio declina monotonicamente durante oito anos, o número de pessoas mortas pela polícia tem aumentado sazonalmente no período. Em 1999, cerca de 664 pessoas foram mortas por policiais no Estado. Cinco anos depois, 915 nãopoliciais perderam suas vidas em confronto com as forças policiais. Por que tantas mortes? Por que a sociedade brasileira convive diariamente com adolescentes sendo mortos pela polícia e com policiais com alto risco de morte durante sua atividade profissionais? Cidadãos feridos em situações de risco que não deveriam existir? Compreender esse dramático quadro não é só uma questão social, mas também um desafio intelectual, que se propõe a pesquisa de doutorado Letalidade da ação policial e teoria interacional: análise integrada do sistema paulista de segurança pública.

Em principio, o uso da força ocupa papel central na atividade policial, incluindo a força letal (Bittner, 1970). O que difere os policiais das demais pessoas é que eles são autorizados legalmente a recorrer à coerção física no comprimento do seu dever profissional (Mesquita, 1999). Mas se, no entanto, a utilização da violência é parte integrante do trabalho policial, a força deve ficar dentro dos preceitos legais e legítimos da sociedade. Sendo assim, a questão que emerge é qual a quantidade de violência necessária para manter a ordem. Existe grande dificuldade de definição normativa sobre a quantidade de força física legítima dentro de um Estado democrático. Por exemplo, a ONU (Organização das Nações Unidas) recomenda que a letalidade deva ficar restrita aquelas situações em que todos os outros recursos foram esgotados para a garantia da vida do policial e de terceiros. A despeito de instrumental, a definição da ONU sobre a legitimidade do uso da ação letal pouco contribuí na construção de indicadores claros sobre a quantidade de letalidade razoável no provimento do serviço de segurança pública. O FBI trabalha com uma 
projeção de 12 não-policiais mortos para cada policial morto em confronto armado. Para se ter uma idéia da dificuldade de mensuração do problema, a proporção média de pessoas mortas em confronto com a polícia nos Estados Unidos é de 4,4 nãopoliciais mortos para cada policiais. (Stock, Borum, e Baltzley, 1996). A literatura aponta que numa relação de confronto armado de segurança pública, o número de não-policiais mortos é em média quatro vezes maior do que número de policiais (Cano, 1997). A situação em São Paulo indica um excessivo uso da ação letal da polícia. A média da amostra é de 9,29 pessoas mortas por policiais para cada policial morto. Em apenas um ano, a relação foi inferior a quatro não-policiais mortos para cada policial morto.

O uso da força letal pelas instituições responsáveis pelo controle do crime e da violência não tem passado desapercebido na produção das Ciências Humanas nacional. Pesquisadores como Paulo Sérgio Pinheiro, Teresa Caldeira, Sérgio Adorno, Julita Lemgruber, Inácio Cano, entre outros, têm, desde meados da década de oitenta do século passado, chamado a atenção para as altas taxas de mortes em confronto com a polícia nos grandes centros urbanos brasileiros. No entanto, uma das principais características comum a nossa produção sobre o tema é a subordinação da análise sistemática do objeto à discussão normativa. A produção acadêmica sobre a letalidade da ação policial foi fortemente influenciada pela recente história política do país. A associação entre a retomada do regime democrático, nos meados da década de oitenta do século passado, com a não-conversão automática do padrão de letalidade da ação policial, ao nível característico das democracias consolidadas, levou a grande maioria dos trabalhos sobre o tema a identificar a letalidade como um instrumento de resistência dos grupos sociais conservadores à nova ordem política. Portanto, mais do que entender os fatores que levam às altas taxas de letalidade da ação policial, o fundamental seria denunciar os perigos políticos associados ao arbítrio policial. Esse trabalho se afasta dessa abordagem ao apresentar a letalidade da ação policial como principal foco de análise. Ou seja, ao invés de uma investigação sobre o funcionamento do regime político ou sobre a configuração da atual sociedade 
paulista, a pesquisa tenta responder quais são os determinantes de letalidade da ação policial. Para tanto, o doutorado busca construir um modelo de ação que apreenda toda a complexidade na qual está envolvido o trabalho policial.

Levando-se em consideração que policiamento está relacionado com manutenção da ordem social, combate direto à atividade criminal, policiamento judiciário e atendimento aos casos de desordem social de caráter não criminal as atividades policiais podem ser classificadas de acordo com o seu grau de periculosidade. A manutenção da ordem social e a atendimento aos casos de desordem pública não-criminais são atividade de rotina que são potencialmente potencialmente conflituosas. Já, as outras atividades são francamente conflituosas, envolvendo o confronto direto com as pessoas que cometeram crimes, e atos de violência, e a investigação dessas ocorrências. Ou seja, é nesse ambiente de risco que ação policial se desenvolve. Mas, como se não bastasse essa peculiaridade, a ação policial, também, interagem com variais dimensões sociais simultaneamente.

A ação policial é realizada no ambiente onde a dimensão política, econômica, social e simbólica se confluem e relacionam-se em uma teia complexa de mecanismo de causalidade. O policial dentro de suas obrigações profissionais tem que tomar decisões sobre a melhor maneira de resolver uma situação de crise. A racionalidade do policial, o desenho institucional, o contexto social, o treinamento recebido e os valores compartilhados são alguns dos elementos que explicam a ação policial. Levar em conta essa complexidade é absolutamente fundamental para entender o problema e, principalmente, para criar mecanismos públicos de controle da letalidade. $\mathrm{O}$ modelo interacional de ação policial proposto determina que a letalidade policial acontece na interação entre a ação racional dos policiais, o contexto urbano, ou os riscos potenciais que os policiais enfrentam na sua atividade diária, o posicionamento institucional em relação à letalidade e o padrão ecológico no qual está inserida a corporação em que o policial está lotado. Defende-se a hipótese de que a interação entre esses fatores determina a probabilidade de uma ação policial ser letal. Mas, o que vem a ser uma ação letal da polícia? Ou melhor, como separar ações que estão 
diretamente relacionadas ao policiamento do espaço público daquelas onde estão presentes interesses privados. A hipótese subjacente da tese é que tanto as ações dos policiais que terminaram em mortes de pessoas durante a prestação de serviço de segurança pública, como aquelas mortes nas quais as motivações dos policiais são menos evidentes estão relacionadas ao mesmo conjunto de determinantes.

Sendo assim, o objeto de estudo é a ação letal da polícia paulista em folga ou em serviço. Os estudos sobre as instituições policiais definem seus objetos como violência policial, (Caldeira, 1991, Pinheiro, 1991a, Pinheiro e colaboradores, 1991b, entre outros), letalidade policial (Cano, 1997) ou brutalidade policial, (Mitchell e Wood, 1999). Nesse trabalho optou-se por ação letal da polícia, pois o termo violência abrange uma quantidade maior de atitudes e de ações que resultaram em mortes de cidadãos ou policiais e traz implícito uma legalidade relativa da ação (Mesquita, 1999). Como foram separadas as ações que podem ser consideradas legais, daquelas que constituíram abuso de poder, uso excessivo da força ou execuções sumárias, o conceito não foi utilizado. O conceito de letalidade da ação está associado aos indicadores de letalidade, como a pesquisa não recorreu a esses indicadores, a utilização desse outro termo também ficou prejudicada. Quanto ao conceito de brutalidade da ação policial, além da sua pouca utilização na literatura nacional, sua definição é mais elástica (assim como acontece com violência policial) do que caberia ao objeto de estudo do trabalho. Sendo assim, o termo escolhido, ação letal da polícia, sintetiza com mais precisão as interações entre policiais e não-policiais em que um dos lados do confronto teve pessoas feridas letalmente, revelando com mais exatidão o assunto da pesquisa..

Quanto ao recorte temporal, o trabalho analisará os casos de letalidade que ocorreram na cidade de São Paulo entre 2001 e 2003. As ocorrências de letalidade foram agregadas ao nível dos 93 distritos da jurisdição administrativa da SSP-SP. Todas as mortes de autoria de policiais militares como de policiais civis formam o universo da pesquisa. A despeito da maior participação da Polícia Militar nos eventos que resultaram em mortes de cidadãos ou de policiais, a acrescente participação de 
policiais civis em confronto e a tentativa de estabelecer o impacto do sistema político na dinâmica da ação letal da polícia justificaram a opção. Não estão contempladas na análise as demais forças policiais, tais como Polícia Federal e polícias municipais. As últimas foram excluídas da pesquisa, pois não foram encontrados dados sobre suas ações e porque não respondem constitucionalmente pelo combate ao crime e à violência, apresentando funções laterais de controle da criminalidade. Outro fator que embasa a decisão, foi a questão do controle institucional, pois essas forças respondem ao município. Fora, portanto, do escopo da pesquisa. O mesmo motivo justifica a exclusão da Polícia Federal da análise.

Um dos principais problemas que enfrentam os pesquisadores do sistema de segurança público é o acesso a dados confiáveis. Há dados confiáveis sobre a ação da polícia em São Paulo? É uma pergunta que ronda o pesquisador que estudar as forças policiais. As organizações policiais são instituições fechadas nas quais o controle do fluxo de informação faz parte do ethos de seu trabalho. O que dizer de estudar uma das partes ainda mais sensíveis da organização, como é a letalidade de sua ação? Portanto, suspeitar da acessibilidade, da validade e da confiabilidade dos dados sobre pessoas mortas pela polícia é razoável.

Tive a sorte, como pesquisador, de entrar em contato com um material rico e não explorado sobre ação letal da polícia na cidade de São Paulo. Em dezembro de 2003, integrei a Comissão de Letalidade da Secretaria de Segurança Pública do Estado de São Paulo, formada para monitorar continuamente os casos de letalidade sofridos e cometidos por policiais (em serviço e em folga). Entre outras atribuições, a Comissão de Letalidade era responsável pela manutenção e análise de um banco de dados contendo todas as operações em que houve policiais e não-policiais mortos, a partir de 2001. Além disso, tive a pesquisa A corregedoria e a ação letal da polícia paulista contemplada com um prêmio da Secretaria Nacional de Segurança Pública (SENASP). A SENASP forneceu todos os dados necessários para gerar meu relatório. Esses dois fatos permitiram-me entrar em contato com um rico e inédito material sobre letalidade da ação policial. 
Essa tese de doutorado está dividida em cinco capítulos, alem dessa introdução. O próximo capítulo apresenta uma revisão da produção teórica sobre a letalidade da ação policial. Nele, retoma-se a exposição desenvolvida na dissertação de mestrado sobre os avanços, os limites e as lacunas em relação à discussão acadêmica sobre excessiva utilização da força letal na ação policial (Oliveira, 2004). Longe de se empreender uma revisão exaustiva da literatura da área, já realizada no trabalho anterior, essa parte do texto apresenta a recente produção sobre letalidade, construindo, assim, o campo analítico com o qual a tese de doutorado dialoga.

No segundo capítulo, serão apresentadas as teorias sobre letalidade: i) racional, ii) institucionalista e iii) ecológica. Nessa parte, serão esboçados, ainda, os contornos do modelo teórico interacional, que se acredita ser o mais adequado para compreender as altas taxas de letalidade da ação policial em São Paulo. Essa secção é dedicada, ainda, à exposição da formalização do modelo interacional e da estratégia de análise que permite a verificação empírica do modelo teórico proposto na tese de doutorado.

$\mathrm{Na}$ terceira parte, serão apresentados os dados sobre a letalidade da ação policial presentes no banco de dados da Comissão de Letalidade da Secretaria de Segurança Pública do Estado de São Paulo. Tal fonte de dados constitui a principal base empírica do trabalho e contém informações detalhadas de grande parte dos casos envolvendo policiais e não-policiais mortos em confrontos na cidade de São Paulo, desde 2001. Os dados das mortes foram agregados ao nível da jurisdição territorial do Batalhão de Polícia Militar. Esse procedimento propicia a comparação dos vários perfis ecológico-comunitários existentes na cidade, o contexto criminal e as diferenças institucionais entre os distritos. Expõem-se, ainda, as estatísticas descritivas das mortes pela polícia e das variáveis independentes da tese.

No quarto capítulo, o modelo teórico interacional é confrontado com os dados empíricos. As regressões multivariadas permitiram a comprovação do ajuste do modelo à realidade paulista. Todos os testes de validação foram positivos e as hipóteses teóricas alternativas não mostraram as mesmas consistências. A concepção 
tradicional de que os modelos paradigmáticos são concorrentes não é sustentável empiricamente. Como predito pela teoria interacional, os modelos teóricos paradigmáticos são dimensões distintas do mesmo plano analítico sobre o comportamento policial. A ausência das variáveis criminais, socioeconômicas, institucionais e ecológicas representa um erro de especificação do modelo teórico e das análises estatísticas. Nem mesmo a visão de que alguns desses fatores são controles da verdadeira explicação paradigmática apresentou qualquer respaldo empírico. O quarto capítulo apresenta, também, os desdobramentos políticos e sociais dos resultados encontrados durante a pesquisa. Será demonstrado que a teoria interacional além de consistente teoricamente, possibilita a construção de políticas públicas de controle da letalidade e auxilia a desvendar o efeito da letalidade no sistema de segurança pública.

O último capítulo é dedicado às considerações finais da tese. Não serão feitas afirmações categóricas sobre os resultados encontrados. Mas, destacaremos a agenda de pesquisa que se abre com o modelo interacional. A letalidade policial é um assunto que não se reduz a disputas epistemológicas. O rigor metodológico não pode se sobrepor à agenda política. Espera-se, sinceramente, que o esforço analítico sirva de base para uma discusão mais técnica sobre as nossas opções políticas na área de segurança pública. As vidas das pessoas não podem estar sujeitas às interpretações preconcebidas. A gravidade de nossos problemas sociais não permite que continuemos preocupados com disputas metodológicas, teóricas e ideológicas. 


\section{Capítulo 1}

\section{Ciências Sociais e ação policial}

O comportamento da polícia tem merecido menos atenção na pesquisa social do que sua importância relativa para o funcionamento da sociedade indicaria. As instituições policiais são vistas muitas vezes como apartadas da sociedade e as pesquisas sobre elas são consideradas simplificações da complexidade social. Soma-se a isso que estudá-las implica assumir a necessidade de autocontenção das liberdades sociais e admitir a importância dos controles coletivos. Não é de surpreender que as instituições policiais sejam pouco pesquisadas (Bayley, 1995).

A produção brasileira sobre polícia foi fortemente marcada pela recente história política do país. Caldeira (2000) relaciona a não-conversão da forma de atuação das instituições à peculiaridade da relação entre sistema político e a constituição histórica da cidadania civil. Para essa autora, o sistema político brasileiro é uma "democracia disjuntiva", pois apresenta um descompasso entre a cidadania política, garantida plenamente após a Constituição de 1988, e a efetivação dos direitos civis, que continuam a ser violados por agências do Estado brasileiro. Caldeira busca uma conexão entre as estruturas sociais e de personalidade no processo de pacificação social. Nesse sentido, o padrão de ação policial, aparece como sendo "constitutivos das instituições de ordem brasileira, da dominação de classe, do padrão de expansão dos direitos do cidadão, e, portanto, da própria democracia brasileira" (Caldeira, 2000). Caldeira conclui, então, que "em toda essa história da relação entre polícia, sociedade e Estado, o único elemento sistematicamente ausente é a vontade política das autoridades estatais, e dos cidadãos, de controlar o comportamento abusivo da polícia" (Caldeira, 2000).

Pinheiro (1991b), assim como Caldeira, vincula a análise do sistema policial ao regime político. O regime democrático requer que a economia e as interações sociais na sociedade civil, além do Estado e das instituições políticas, também sejam 
democratizadas. No modelo proposto por Pinheiro, o padrão de atuação das forças policiais sob o regime democrático está relacionado com interações (simbólicas e econômicas) no interior da própria sociedade. Pinheiro analisa a persistência das práticas arbitrárias, por parte dos agentes do Estado, como resultado de uma cultura política autoritária, que sempre marcou a sociedade brasileira, "onde as relações de poder tradicionalmente se caracterizaram pela ilegalidade e pelo arbítrio ao qual a maioria da população deve submeter-se, as práticas autoritárias não afetadas pelas mudanças institucionais" (Pinheiro, 1991b). Na hipótese de Pinheiro, o padrão de organização do sistema policial interage com a cultura política autoritária disseminada na sociedade, resultando em um instrumento poderoso de dominação de classe. A utilização sistemática da violência extralegal pelas instituições responsáveis pela segurança pública funciona como "um recurso permanente de que se valem os grupos dominantes para a manutenção e a salvaguarda de seu poder” (Pinheiro, 1991b). Assim, qualquer tipo de reforma que vise à mudança de comportamento das instituições encontrará um óbice na cultura política, a qual legitima soluções e práticas violentas, sejam estatais, sejam privadas. Pinheiro apresenta uma explicação sistêmica do problema da violência policial. Embora dirija sua atenção para as microdimensões do poder, "as microcenas, onde ocorrem as interações concretas entre as pessoas e a sociedade", inadvertidamente, Pinheiro cunha o macroconceito de "autoritarismo socialmente implantado" como sendo o que melhor explica o comportamento policial. Ao propor esse tipo de explicação, Pinheiro apresenta as práticas extralegais das polícias como uma característica inerente ao Estado brasileiro. E, assim como Caldeira, o viés normativo da análise de Pinheiro é patente. Além disso, não se encontra no autor modelos multivariados de análise empíricos.

Cano (1998), em esforço de verificação empírica do padrão de atuação do policial no Brasil, destaca a importância do governo, aproximando-se, portanto, de uma vertente mais institucional-profissional de análise da letalidade policial. Segundo Cano, os governos são capazes de implementar políticas de estímulo à letalidade, como no caso da política de Promoção por Ato de Bravura, mas o autor mostra-se mais 
recalcitrante em relação à eficácia de políticas de controle da letalidade, como o PROAR. Outro ponto pouco discutido no trabalho refere-se à falta de discussão sobre a corregedoria de polícia. Mas uma vez, o padrão de ação policial é relacionado a um conjunto de possíveis mecanismos causais, o desenho institucional das políticas públicas de segurança coletiva.

Os estudos etnográficos realizados no período apontam claramente a necessidade de se sofisticar o arcabouço teórico-explicativo sobre o comportamento policial no Brasil. A pesquisa feita por Minguardi (1992), que realiza uma observação participante do trabalho da Polícia Civil em São Paulo, nos primeiros anos do governo Franco Montoro, demonstra a resistência enfrentada pelo primeiro governador eleito democraticamente na implantação de uma política de direitos humanos dentro da Polícia Civil paulista. Outra pesquisa etnográfica que tenta apreender a lógica do trabalho policial foi realizada por Lemgruber (1986), na cidade do Rio de Janeiro. A autora investigou a visão de mundo e representações do policial civil carioca, na tentativa de apreender os problemas enfrentados pelo governo de transição democrática, de 1982 a 1984, período em que Leonel Brizola tenta implementar uma política de respeito aos direitos humanos e à cidadania. Foi criado, no governo de Brizola, o Conselho de Segurança Pública e Direitos Humanos com o objetivo de propagar uma política de segurança pública respeitando às liberdades individuais e coletivas. E junto com o Conselho, subordinado diretamente ao governador, é inaugurada a Assessoria Especial para acompanhar os casos de violações dos direitos humanos. O período é marcado, também, por uma crescente resistência dos policiais civis à linha progressiva adotada pelo governo na questão da segurança pública.

Lemgruber (1986), assim como Minguardi (1992), demonstra que, a despeito da fragilidade dos governos executivos estaduais frente às resistências internas às corporações policiais, houve um reiterado esforço político no sentido de mudar a forma de atuação da polícia. A própria resistência à mudança confirma a complexa relação entre o campo político e a organização policial, mas também demonstra 
claramente a mudança de enfoque do regime político. As pesquisas nacionais simplificam a relação entre o sistema político e as organizações policiais ao assumir uma postura determinista das relações sociais que cercam as questões de segurança pública. Para Zaluar (2001), a relação entre o plano teórico e a realidade políticoinstituticional do país explica, em parte, a carência metodológica dos estudos sobre as instituições policiais no Brasil. O regime autoritário, que contou com o suporte das instituições responsáveis pelo sistema de segurança pública, levou os intelectuais a se ocupar mais com as questões éticas e sociais dos estudos penológicos do que com seus aspectos teóricos e analíticos.

A produção internacional sobre o tema, um pouco mais extensa do a nacional, não estuda a relação das instituições policiais com regime políticos. Sendo sim, uma abordagem do tipo institucional que busca dimensionar o impacto das variáveis políticas na forma de atuação da polícia é pouco desenvolvida (Crank e Langworthy, 1992). Os trabalhos existentes sobre o assunto são voltados para a construção de novas práticas (Skogan e Hartnett, 1997) e avaliação de policiamento e suas formas (Bayley e Skolnick, 1986). Os estudos voltados especificamente para o comportamento policial apresentam, em sua maioria, caráter descritivo e normativo (Pinheiro, 1991; Chevigny, 1995). Portanto, ainda são poucos os trabalhos teóricos sobre letalidade da ação policial (Mesquita, 1999).

Mesquita (1999) apresenta uma revisão dos principais modelos teóricos sobre a letalidade da ação policial. Segundo o autor, existem quatro abordagens teóricas sobre o tema. A primeira destaca os aspectos legais do uso da força por parte da polícia. A grande diferença entre policiais e não-policiais é que o primeiro grupo pode legalmente utilizar a força física, inclusive a letal, no cumprimento de seu dever profissional, já o segundo grupo pode recorrer a ela em casos restritos. Neste modelo, a ação do policial ganha importância quando este utiliza a força física de forma não relacionada ao cumprimento legal de seu dever profissional.

O segundo modelo prevê o uso legítimo da força. Para Mesquita, essa abordagem distingue os conceitos de força e de violência não com base apenas na legalidade, 
como no primeiro modelo, mas também partindo da legitimidade da força. Dessa maneira, as ações dos policiais não são analisadas apenas segundo o critério de legalidade, mas também de acordo com o critério de legitimidade do uso da força letal.

O terceiro refere-se, por sua vez, aos critérios sociais ou jornalísticos de julgamento da violência policial. Assim, a ação da polícia, embora legítima e legal, enfrenta desaprovações pontuais da sociedade ou da imprensa. Nessa concepção, a ação letal tem relevância teórica de acordo com a posição social em relação às instituições policiais.

O último modelo teórico, apontado pelo autor, parte de uma definição profissional de violência policial. Dessa forma, a ação letal passa a ser pesquisada não segundo critérios legais, legítimos ou normativos da força empregada, mas de acordo com critérios profissionais. Isto é, a utilização da força letal deve ser analisada segundo os parâmetros que alguns profissionais, altamente capazes, consideram necessários para determinada situação de confronto. Com isso, a força da ação policial está relacionada ao ambiente de interação entre policiais e não-policiais, ao tipo de treinamento para a interação, aos critérios institucionais de utilização da força possivelmente letal e ao grau de discricionariedade do agente de ponta (policial).

A revisão da literatura de Mesquita expõe a principal lacuna nos estudos sobre o tema. É patente a ausência de um modelo teórico sobre a ação policial. A ação letal da polícia está diretamente relacionada a uma gama extensa de fatores sociais. Como exceção das ações de extermínio ilegais realizadas, a ação letal do policial acontece em situação de combate ao crime e a violência. $\mathrm{O}$ policial dentro de suas obrigações profissionais tem que tomar decisões sobre a melhor maneira de resolver uma situação de crise. O escalonamento racional sobre a melhor opção a ser elegida é feito em um cenário de alta imprevisibilidade, com altos riscos individuais, e para outros envolvidos. O desenho institucional em que o policial está inserido, as histórias de vida pessoais, o contexto social da ocorrência, o treinamento recebido, os valores compartilhados entre os policiais e a percepção do risco enfrentado são alguns dos 
elementos que explicam o desfecho letal da ação policial. Levar em conta essa complexidade é absolutamente fundamental para entender o problema e, principalmente, para criar mecanismos públicos de controle da letalidade.

Nesse sentido, proponho a construção de um modelo teórico interacional da ação policial, onde a letalidade policial acontece pela interação entre a ação racional dos policiais, o contexto urbano, ou os riscos potenciais que os policiais enfrentam em sua atividade diária, o posicionamento institucional em relação à letalidade e o padrão ecológico no qual a corporação do policial está inserida. Defende-se a hipótese de que a interação entre esses fatores determina a ação policial ser letal. A probabilidade de um evento acontecer é a unidade de análise teórica. Essa opção afasta a pesquisa do individualismo metodológico, uma vez que o indivíduo não é a unidade analítica, do determinismo social, já que as superestruturas sociais não aparecem como elemento explicativo das decisões individuais. O modelo interacional aqui proposto é resultado de integração horizontal da teoria da escolha racional, do institucionalismo e da teoria da ecologia urbana - detalhadas no próximo capítulo.

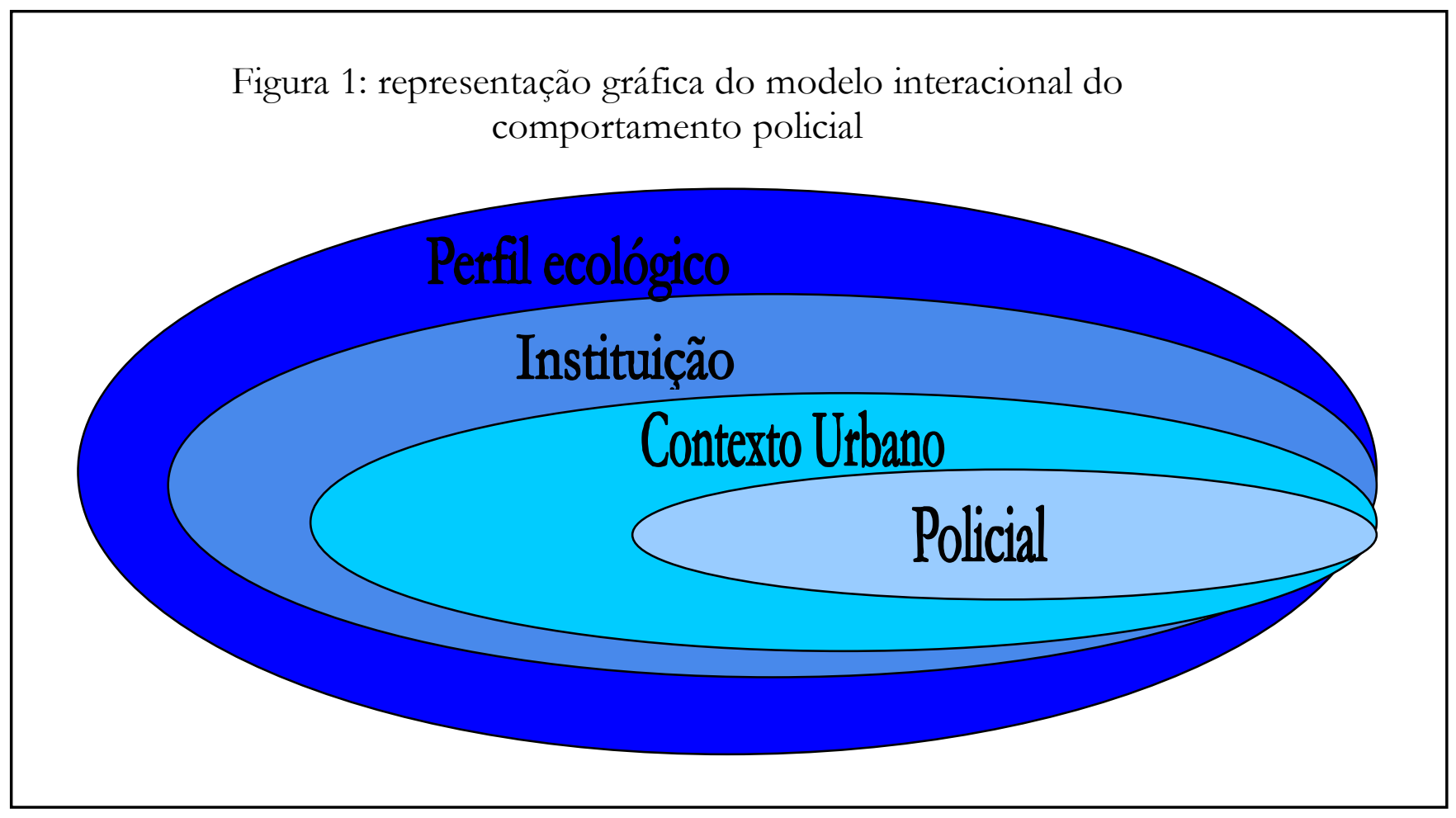


$\mathrm{Na}$ figura 1, os modelos teóricos paradigmáticos não vistos como concorrentes. O comportamento dos atores sociais sofre influência simultânea de fatores microssociais e macrossociais. O policiamento é fenômeno social multidimensional e multi-fatoral e requer, portanto, uma modelagem teórica complexa se quisermos compreendê-los. O pressuposto racional do policial é o ponto de partida do modelo teórico interacional. As primeiras tentativas de uma abordagem teórica sobre o crime e a violência ocorreram no final de século XVIII com os trabalhos de Lombroso (Beirne, 1998). Fortemente marcada pelo positivismo, a criminologia clássica entendia o crime e a violência como derivados das características biológicas do criminoso. A ênfase dos estudos pioneiros na área recaía, nesse sentido, na análise das variáveis relacionadas à oportunidade de se cometer um crime. Como, segundo a teoria clássica, existem características biológicas inerentes aos indivíduos criminosos, a única saída para o controle do crime é diminuir as oportunidades que favorecem o delito. Akers (1990) aponta as conexões existentes entre os modelos criminológicos clássicos e as concepções modernas a respeito do crime. Segundo o pesquisador, o ponto de contato entre os primeiros modelos teóricos e as concepções modernas sobre o crime , tais como a teoria da escolha racional, é o enfoque na dissuasão (deterrence) como elemento de controle social. Segundo Cornish e Clarke (1988), a grande diferença entre as concepções clássicas e as atuais é o grau de discernimento dos atores envolvidos na atividade criminal. A premissa básica da escola da escolha racional é de que os atores respondem seletivamente aos fatores exógenos ao ato criminal, tais como oportunidade, custo e benefício, na tomada de decisão individual (Becker, 1968). Já para os modelos clássicos, marcados pelas concepções biologizantes do comportamento anti-social, o poder discricionário do ator é reduzido. Outro ponto de aproximação, entre as teorias clássicas e as teorias racionalistas sobre o crime, é o foco no indivíduo como unidade analítica. Atores racionais ou com má formação psicobiológica são propensos a cometer um ato criminoso independentemente de sua história de vida, rede de sociabilidade ou contexto social em que estão inseridos. $\mathrm{O}$ 
que leva ao ato ilícito é o contexto situacional, a probabilidade de sucesso da ação. Os fatores macrossociais são exógenos à tomada de decisão ao nível individual.

A transposição do modelo criminológico clássico, em menor medida, e racionalista, mais intensamente, sobre crime e violência para análise das organizações policiais é representado, esquematicamente, pela teoria situacional. Segundo Friedrich (1980), a principal característica do modelo situacional é a ênfase nos incentivos sociais que estruturam a tomada de decisão individual do policial. Tais incentivos são basicamente de duas ordens: socioeconômicas e criminais. Os incentivos para tomada de decisão dos policiais são realizados em uma situação de alta discricionariedade individual e com baixa supervisão institucional (Mastrofski, 2004). O perfil social e cultural dos envolvidos nos encontros de policiamento determina o grau de periculosidade da interação entre policiais e não-policiais e molda de maneira decisiva o comportamento dos agentes públicos de segurança. Além das características pessoais dos não-policiais, os perfis socioeconômico e criminal estruturam, também, o comportamento individual. Policiais lotados em cidades e em distritos com altas taxas de crimes ou fatores que potencialmente levam ao aumento da criminalidade ou do comportamento violento - tais como o baixo nível de renda ou qualquer outro fator relacionado com os incentivos ao crime e à violência - agiriam de maneira diferente da de policiais lotados em lugares onde tais fatores não estão presentes (Terrill e Reisig, 2003). O modelo clássico e o modelo racionalista são fortemente criticados na literatura criminológica pela excessiva ênfase no comportamento individual do criminoso (ou do policial) e por desconsiderarem as variáveis ecológicas e as variáveis institucionais que condicionam a tomada de decisão ao nível individual.

A principal tentativa de trazer o arranjo institucional para os estudos sobre a polícia foi realizada por Bayley (1985). Não é de se estranhar que essa empreitada significou o distanciamento entre o arcabouço teórico da criminologia e os estudos sobre a polícia. As organizações policiais são controladas pelo sistema político (White, 2003), possuem uma forte cultura institucional (Alpert e Dunham, 1992) e apresentam uma complexa estrutura burocrática (Reiss, 1992). Segundo Bayley, os estudos 
criminológicos não possuem instrumental analítico para compreender todas essas dinâmicas sociais, culturais e institucionais, que influenciam o tema.

Sendo assim, o pesquisador apresenta um modelo neo-institucionalista que combina três dimensões analíticas para os estudos das forças policiais: i) dimensão histórica, ii) dimensão política e iii) dimensão burocrática. Nesse sentido, as instituições policiais serão tratadas como regras e procedimentos formais e informais inerentes à estrutura organizacional que edificam o comportamento dos agentes de segurança pública. O ponto central da teoria institucionalista é o processo de formação de preferências do policial. As instituições policiais não apenas constrangem as interações sociais dos seus membros, como, também, alteram sua forma de atuação profissional. As preferências neste modelo são endógenas, ou seja, elas são construídas politicamente. O sistema político, as opções estratégicas das organizações, seus processos seletivos, as relações com outras organizações estatais são alguns dos fatores que não somente blindam os policiais das dinâmicas sociais, mas também incutem uma visão de mundo peculiar nos seus membros.

A contribuição da teoria institucionalista nos estudos sobre as organizações policiais é marcante. A introdução dos aspectos burocráticos, dos constrangimentos institucionais e do papel do comando no processo de organização institucional é fundamental na compreensão das organizações policiais. Mas, se há um avanço na introdução de uma postura neo-institucional, existe, na mesma medida, uma sensível perda analítica na redução do papel das variáveis sociais, econômicas e ecológicas. As organizações policiais, como todas as organizações estatais, apresentam uma complexa relação com o meio ambiente social, com a história e com a cultura do lugar onde estão inseridas. Ou seja, instituições estatais apresentam desempenhos diferentes de acordo com o espaço sociogeográfico que ocupam (Putnan, 2000). Ignorar isso, tal como menosprezar o papel da instituição, significa uma enorme lacuna analítica nos estudos sobre as instituições responsáveis pelo combate ao crime e à violência.

A primeira fonte de ataque às teorias criminológicas microssistêmicas é realizada por Shaw e McKay (1942). Segundo os pesquisadores, o comportamento 
anti-social está fortemente relacionado com o tipo de sociabilização primária dos indivíduos. Se a comunidade apresenta uma rede de sociabilidade sólida e estruturada, o efeito no comportamento individual será um; se existe desestruturação na rede de sociabilização, o efeito será outro.

Ou seja, os pesquisadores trabalham com a hipótese de que a concentração da violência em determinadas áreas da cidade está conectada com as características morfológicas e simbólicas dessas comunidades. Tais características estão associadas à estabilidade populacional, ao nível de participação comunitária, principalmente de caráter religioso, à presença dos pais no desenvolvimento dos filhos, ao relacionamento estreito com os vizinhos, entre outras. Todas essas características comunitárias, que, na visão de Shaw e McKay, não estão diretamente relacionadas ao nível econômico da comunidade nem às instituições estatais, favorecem a criação do sistema de referência cultural no bairro que impede a adesão dos jovens ao sistema de referência anti-social (Bursik, 1998). Em pólo oposto, a ausência de tais características resulta em uma comunidade desorganizada socialmente que favorece o desenvolvimento do sistema de referência cultural mais flexível ao comportamento violento. Portanto, para Shaw e McKay, é a presença de organização ou de desorganização que está relacionada com o nível de crime na comunidade, e não a presença ou ausência de famílias com alto poder aquisitivo ou presença de indivíduos com características criminogênicas (Bursik, 1992). Sendo assim, segundo os teóricos da ecologia humana, todas as explicações que não incorporam uma dimensão supraindividual não conseguem compreender o comportamento criminal (Sampson e Groves, 1989).

Bursik (1998) aponta quatro tipos de problemas nos trabalhos ecológicos iniciais: i) dificuldade de explicar a relação de causalidade entre estabilidade populacional do bairro, homogeneidade racial, status socioeconômico e desorganização social; ii) dificuldade de explicar as variações das taxas de crime dentro dos bairros; iii) problema de confiabilidade dos dados sobre desorganização social (percepção de desorganização social); e iv) baixa valorização das variáveis 
individuais (racionalidade dos atores). A superação dos problemas apontados por Bursik foi fundamental para a consolidação dos estudos ecológicos do crime e da violência. Uma grande contribuição nesse sentido foi a integração analítica entre as variáveis individuais e as variáveis ecológicas, introduzida por Brantingham e Brantinghan (1981) e por Cohen e Felson (1980), com a teoria da atividade de rotina do lugar, que propõe que o espaço urbano é uma variável interveniente da tomada de decisão na atividade criminal. Outra contribuição importante foi a mudança da ênfase no conceito de desorganização social, encarado inicialmente como uma medida objetiva para as variáveis relacionais subjetivas, tais como confiança e solidariedade, como mecanismos que estruturam o quadro de referência social do espaço urbano (Messner, 2004 e Sampson, 1997). Por fim, temos o desenvolvimento da técnica de survey associada à utilização do modelo de regressão hierárquico, que permitiu aumentar a confiabilidade da mensuração do impacto das variáveis macrossociais no comportamento individual (Sampson, 1997).

A transposição dos modelos ecológicos do universo do crime para a análise das organizações policiais não tem sido, via de regra, incerta. Tal como nos modelos clássicos, os modelos teóricos ecológicos têm dado pouco destaque para o papel da instituição como condicionante da tomada de decisão individual. Pensa-se o comportamento anti-social, e do policial, como resultado direto do perfil comunitário, (Terrill e Reisig, 2003). Assim, existe uma transposição linear do arcabouço explicativo sobre o crime para a análise do comportamento policial, se não se considerar o papel da hierarquia, da burocracia, do treinamento, entre outros componentes diretamente ligados ao trabalho policial (Sherman, 1995).

As limitações da análise institucional ecológica do comportamento policial podem ser enfrentadas com base no recente desenvolvimento da teoria interacional do comportamento policial. Thornberry (1987) critica a tendência das teorias criminológicas que dirigem sua atenção para estruturas causais unidirecionais do comportamento anti-social para examinar as relações dinâmicas que ocorrem na sociedade. Thornberry propõe uma reformulação do arcabouço teórico da disciplina, 
deslocando-a da análise das variáveis estruturais ou das variáveis racionais para a interação entre elas. O modelo proposto assume que existe uma recursividade inerente aos processos sociais que impede estabelecimento de relações de causalidade estática. Deve-se, portanto, descobrir os pontos onde se dão as interações entre as várias dimensões sociais, e não, como tradicionalmente tem sido feito, estabelecer os sentidos das relações de causalidade.

Seguindo a trilha aberta por Thornberry, pretende-se empregar uma teoria interacional sobre o comportamento do policial. Esquematicamente, propõe-se que a ação policial é resultado da interação entre as variáveis institucionais (constrangimentos políticos ou institucionais) e as variáveis contextuais (perfil criminal da região onde os policiais atuam). Tal premissa justifica-se pela especificidade do objeto. Se, por um lado, não podemos menosprezar que as instituições policiais, por natureza, possuem uma forte característica hierárquica, o que reforça a importância dos aspectos formais de controle da ação policial (Reiss, 1992), de outro lado, o poder discricionário do policial na sua atividade é marcante (Mastrofski, 2004). Portanto, certas características criminais estão necessariamente relacionadas com o comportamento do policial. Além do mais, tal como demonstrado para outros tipos de organizações estatais, existe um efeito robusto e independente do perfil ecológico no desempenho institucional da organização policial. Acredita-se que, nesse sentido, devemos recorrer a um relaxamento da parcimônia metodológica em detrimento da análise substantiva. A formalização do modelo interacional, empreendida na próxima secção, aumentará o grau de compreensão da reformulação teórica sugerida nesse doutorado. 


\section{Capítulo 2}

\section{Modelo interacional do comportamento policial}

Nessa secção será apresentado o modelo teórico interacional da letalidade policial. Por uma questão estratégica esquemática, será operacionalizado um modelo simples de ação individual, onde há probabilidade do resultado da ação letal do policial variar em função do nível de criminalidade, que o policial enfrenta no seu trabalho cotidiano, e, num segundo momento, serão incorporados outros fatores relevantes teoricamente, até chegar no modelo ideal sobre a letalidade da ação policial.

O policiamento está relacionado em quatro blocos de atividades principais: i) manutenção da ordem social - onde o foco principal é evitar o crime e a violência, ii) combate direto à atividade criminal - cujo objetivo é impedir que o comportamento criminal ocorra por meio de confronto com os possíveis criminosos, iii) policiamento judiciário - onde se investiga a culpabilidade dos atos criminais e violentos que não foram evitados nas etapas anteriores e iv) atendimentos aos casos de desordem social de caráter não criminal. Pode-se, portanto, dividir o trabalho policial entre as atividades que são potencialmente conflituosas, como a manutenção da ordem social e os atendimentos aos casos de desordem pública não-criminais, as atividades altamente conflituosas, envolvendo o confronto direto com as pessoas que cometeram crimes, e atos de violência, e a investigação dessas ocorrências.

A premissa básica do modelo teórico é que o policial age racionalmente diante do risco potencial que ele enfrenta na suas diárias. Ou seja, os policiais utilizam a força letal legalmente, desde que dose-a de acordo com a necessidade para o comprimento da lei. Evidentemente, essa é uma assunção forte, pois é pouco crível que todas as mortes causadas por policiais são resultado de uma ação legal e dentro do padrão razoável de força necessária para o gerenciamento da situação de conflito. Muitas mortes são resultados de erro de avaliação do perigo que o não-policial 
representava no momento de confronto, despreparo profissional, ação ilegal dos policiais ou acidentes. Como será demonstrado nenhum desses fatores invalidam a premissa básica de que os policiais agem racionalmente no que tange ao recurso a letalidade e que a ação racional está diretamente associada ao nível de atividade criminal que o policial enfrenta no seu trabalho diário.

Quanto maior a quantidade de crime que o policial enfrenta maior o risco dele se envolver em operações de combate ao crime e mais crimes a ser investigados e mais criminosos a serem capturados, atividades altamente conflituosas. A presença de atividade criminal também altera a probabilidade das ocorrências potencialmente conflituosas, como a manutenção da ordem social e o atendimento as ocorrências não criminais, se transformarem em ações letais, já que aguça a avaliação de perigo do policial e aumenta o contato potencial entre as pessoas envolvidas em atos criminais e os policiais, mesmo que o foco da ocorrência não tenha um caráter criminal claro. É possível relaxar a premissa de legalidade da ação policial, já que a presença de ações letais ilegais está fortemente relacionada à atividade criminal, seja por meio da ação de grupos de extermínio comandados por policiais, seja devido a atividade de policiamento privado dos policiais. Assim como, as ações letais resultantes de falhas de formações que levam os policiais a avaliar equivocadamente o risco de vida do policial e dos outros cidadãos em uma situação de confronto. Se todos os policiais são atores racionais e estão, portanto, sujeito aos mesmos fatores situacionais, pode-se criar uma função agregada em determinado período de tempo. Levando em conta esses aspectos, um modelo situacional simplificado da ação policial agregada ao nível distrital pode ser descrito segundo a seguinte equação:

$$
\mathrm{P}(\mathrm{lp})=f\left(\mathrm{C}_{\mathrm{it}}\right)
$$

Onde $\mathrm{P}(\mathrm{lp})$ é a probabilidade de um desfecho letal da ação policial, $\mathrm{C}_{\mathrm{it}}$ é t taxa total de crime, no distrito i no período $t$ em que o policial está de serviço. A representação esquemática da relação entre a probabilidade de letalidade e a dinâmica 
criminal é apresentada no gráfico 1, abaixo. A relação entre o crime e a violência não é linear e sim quadrática. Pressupõe-se que o baixo nível de crime e violência não resulte em morte pela polícia e a probabilidade de letalidade aumente rapidamente com o incremento do crime e depois se estabilize a partir de um determinado patamar na dinâmica criminal. Quando atingido um certo padrão criminal, não existe alteração na probabilidade de letalidade policial devido ao aumento de expertise policial no combate ao crime ou ao esgotamento da estratégia de confronto.

Gráfico 1: efeito da dinâmica criminal no número de pessoas mortas
pela polícia

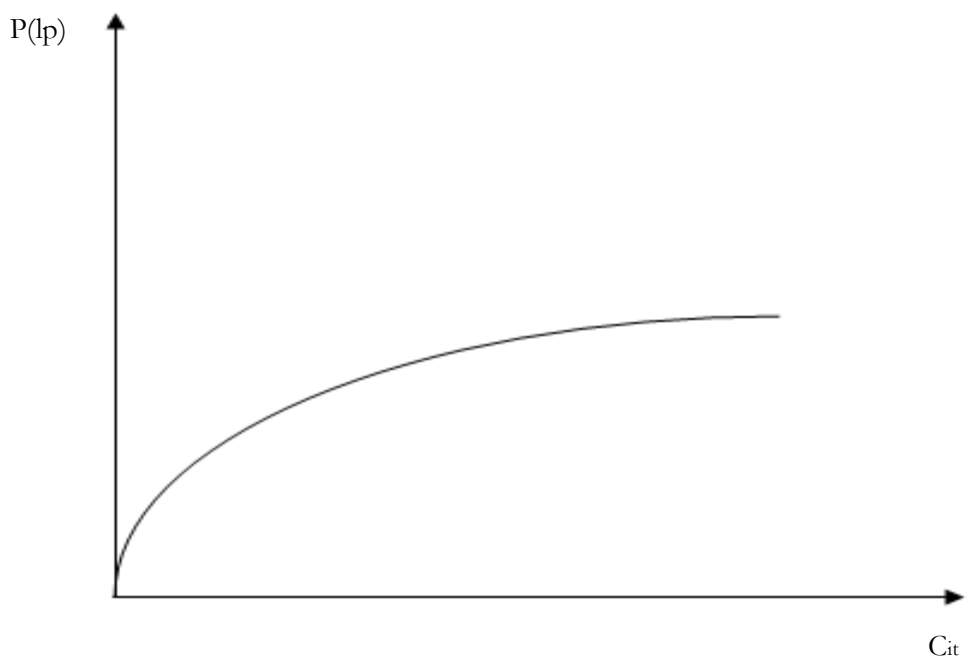

Assume-se que os fatores socioeconômicos apresentam efeito direto no crime, e na violência, e indireto na probabilidade de letalidade. As características socioeconômicas do lugar de atuação do policial são um importante preditor do tipo de atividade criminal presente na área. Existe, ainda, um impacto líquido dos fatores socioeconômicos no crime. Lugares ricos têm mais crimes contra patrimônio e em lugares mais carentes as interações violentas são freqüentes. Isso faz com que o 
policial utilize esses fatores para prever o grau de risco que a ocorrência terá. A estrutura do modelo contextual pode ser descrita, segunda a equação:

$$
\mathrm{P}(\mathrm{lp})=f\left(\mathrm{C}_{\mathrm{it}}, \mathrm{SE}_{\mathrm{it}}\right)
$$

Onde $\mathrm{P}(\mathrm{l} \mathrm{p})$ é a probabilidade de um desfecho letal da ação policial, $\mathrm{C}_{\mathrm{it}}$ é taxa total de crime e $\mathrm{SE}_{\mathrm{it}}$ é o padrão de socioeconômico, no distrito i no período t em que o policial está de serviço. Como pode ser averiguado no gráfico 2 , a introdução das variáveis socioeconômicas lineariza a relação entre as variáveis criminais e a letalidade, já que agrega previsibilidade ao comportamento do policial. Quanto maior o nível socioeconômico da área, menor a tolerância do policial em relação ao comportamento criminal, maior probabilidade de letalidade. Existe, também, uma relação direta entre padrão socioeconômico do distrito e a probabilidade de confronto, já que os distritos mais ricos da cidade apresentam maiores investimentos em segurança privada, têm acesso facilitado a recursos de comunicação e apresentam maiores concentrações de efetivos policiais. Todos esses fatores contribuem para uma polícia mais eficiente e, portanto, aumentam a probabilidade de fragrantes. Isso explica as taxas de mortes pela polícia, estarem concentradas em lugares onde as taxas criminais não são tão acentuadas. 


\section{Gráfico 2: efeito do contexto social no número de pessoas mortas pela polícia}

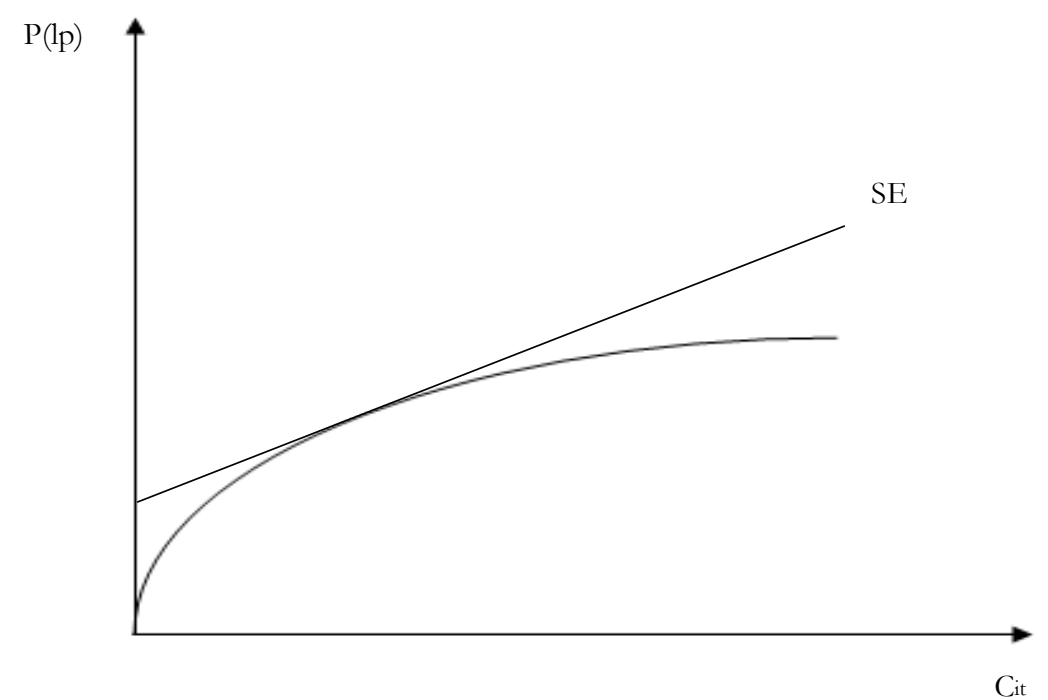

Já o impacto da instituição no comportamento racional dos atores está consolidado na literatura de Economia, de Ciência Política e de Sociologia. Segundo a premissa teórica situacional, a probabilidade de letalidade da ação policial está associada à dinâmica criminal e um efeito aleatório não especificado teoricamente. No entanto, como vimos anteriormente é improvável que o comportamento dos policiais seja exclusivamente associado ao crime e à violência. As instituições policiais e judiciárias apresentam uma expressiva ascensão sobre as preferências dos policiais. As instituições alteram a ordem de preferência dos atores ao alterar os custos associados à algumas opções. No caso da letalidade da ação não é diferente. $\mathrm{O}$ perfil institucional pode ter tanto um efeito positivo como negativo na letalidade. Os desenhos institucionais de segurança pública não estão diretamente relacionados com dinâmica criminal. Por exemplo, um incremento significativo do crime e da violência decorrente de mudanças expressivas na dinâmica sócio-urbana ou da ecologia-urbana pode gerar uma resposta institucional restritiva ao confronto com a valorização do 
policiamento preventivo ou uma resposta belicosa como a implementação de um policiamento proativo. A resposta para o aumento do crime e da violência está relacionada às dinâmicas internas das estruturas sociais responsáveis pela segurança pública, que vai do governo do Estado (para o caso brasileiro) até aos tenentes da Polícia Militar e aos delegados distritais da Polícia Civil (os postos mais baixos na hierarquia de comando da polícia brasileira). Sendo que os fatores sociais apresentam um efeito indireto no comportamento policial, pois estão relacionados ao nível da atividade criminal e violenta. Formalmente, a probabilidade de letalidade no modelo mesmo simplificado de ação policial, é expresso pela seguinte equação:

$$
\mathrm{P}(\mathrm{lp})=f\left(\mathrm{C}_{\mathrm{i},}, \mathrm{SE}_{\mathrm{it}}, \mathrm{I}_{\mathrm{it}}\right)
$$

O gráfico 4 auxilia na visualização do efeito de cada um dos desenhos institucionais no comportamento letal dos policiais. Os desenhos institucionais voltados para o controle da atividade policial apresentam menor probabilidade de letalidade mesmo mantendo todas as outras condições constantes. A curva Inst' do gráfico 3 representa o efeito esperado de uma instituição policial com forte controle e a curva Inst" o efeito de uma instituição policial que incentiva o policiamento mais combativo. Como o modelo teórico não descreve ex antes se o efeito institucional será positivo ou negativo na probabilidade de letalidade da ação policial, o equilíbrio pode estar em qualquer ponto representado pela seta $\mathrm{A}$. 
Gráfico 3: efeito institucional no número de pessoas mortas pela polícia

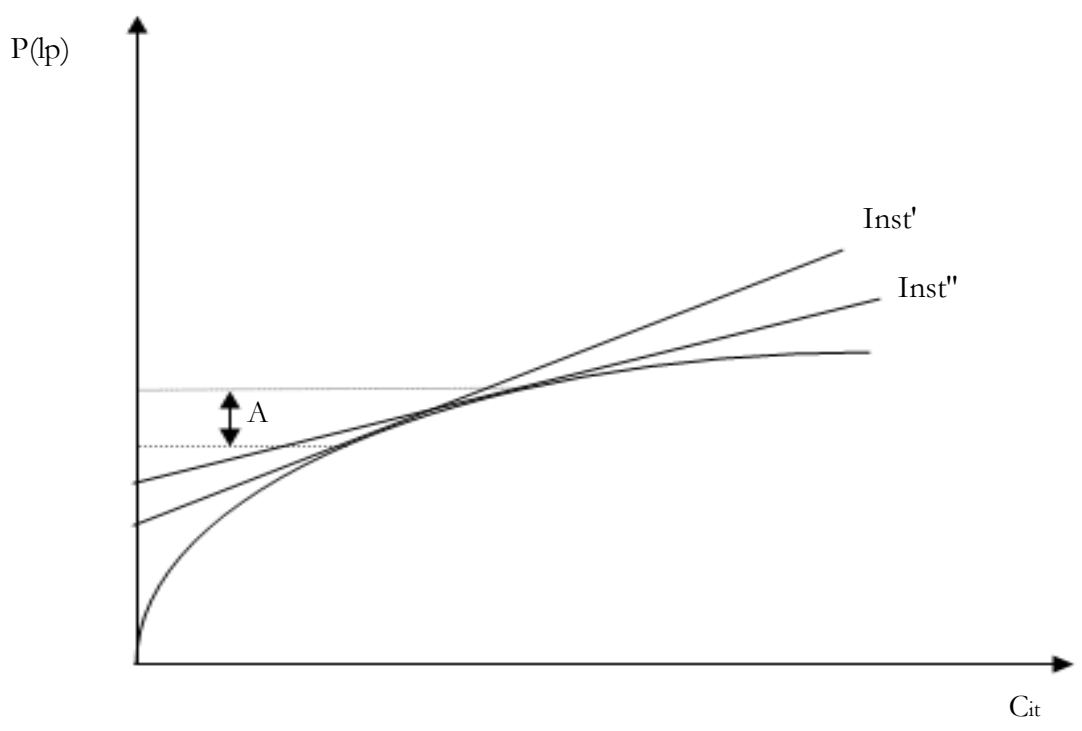

Se na premissa teórica racionalista o comportamento do policial é condicionado pela dinâmica do crime e da violência do lugar de atuação ,e na premissa institucionalista o comportamento é independente da dinâmica criminal, na premissa da teórica ecológica tanto o comportamento individual do policial como a dinâmica criminal é influenciada pela mesma ordem de fatores: o perfil urbanoecológico.

Segundo a teoria ecológica, o crime e a violência se distribuem de maneira desigual no espaço urbano. Mesmo as comunidades com características socioeconômicas parecidas possuem níveis de atividades criminais distintos. Isso ocorre porque tais comunidades apresentam diferentes padrões de envolvimentos de sua população nos assuntos públicos. Por motivos externos às características econômicas e sociais, certos grupos populacionais altamente propensos à resolução de seus problemas comunitários acabam se reunindo no mesmo espaço urbano. Sendo que, a distribuição desigual desses grupos que explica a concentração de crime e de violência em algumas comunidades. As comunidades mais organizadas socialmente 
apresentam uma dinâmica criminal sensivelmente menor do que as comunidades desorganizadas socialmente.

Além do impacto direto no crime, o perfil ecológico da comunidade também altera a latitude de atuação do policial, tendo impacto na letalidade policial independente do perfil institucional da corporação, da dinâmica criminal e das características socioeconômicas do lugar de atuação do policial. Isso porque as comunidades organizadas socialmente controlam mais os policiais, diminuindo os abusos e os erros de avaliação que são reincidentes, também colaboram mais com a polícia, o que facilita a resolução de situações potencialmente conflituosas sem o uso da força e ajuda na identificação dos grupos de policiais com menor competência técnica ou envolvidos com atividades ilícitas (fatores associados a maiores probabilidades de letalidade policial). Formalmente, o impacto do perfil ecológico do lugar é:

$$
\mathrm{P}(\mathrm{lp})=f\left(\mathrm{C}_{\mathrm{it}}, \mathrm{SE}_{\mathrm{it}}, \mathrm{I}_{\mathrm{it}}, \mathrm{E}_{\mathrm{it}}\right)
$$

Onde a probabilidade da letalidade policial permanece associada ao perfil criminal do lugar e de período de atuação do policial $\left(\mathrm{C}_{\mathrm{it}}\right)$, com a diferença de que o perfil criminal sofre influência do perfil ecológico da comunidade $\left(\mathrm{E}_{\mathrm{it}}\right)$. Mesmo quando controlado pelos fatores socioeconômicos $\left(\mathrm{SE}_{\mathrm{it}}\right)$. O gráfico 3 apresenta a relação entre o perfil ecológico da comunidade, a dinâmica criminal e probabilidade de um desfecho letal na ação policial. A curva Ecol" representa a ausência de estruturas comunitárias organizadas no lugar de atuação, segundo o modelo teórico essa situação favorece a consolidação de altas taxas de atividades criminais e, também, forte presença de letalidade na ação policial. A curva Ecol' representa a presença de uma população voltada para resolução de seus problemas coletivos, isso reduz, simultaneamente, a presença de atividade criminal e a probabilidade de letalidade da ação policial. A seta B representa o efeito esperado da presença de altas taxas de 
envolvimento comunitário na probabilidade da ação letal dos policiais. Quanto maior a presença do envolvimento comunitário, menores as taxas de letalidade.

\section{Gráfico 4: efeito da ecologia urbana no número de pessoas mortas pela polícia}

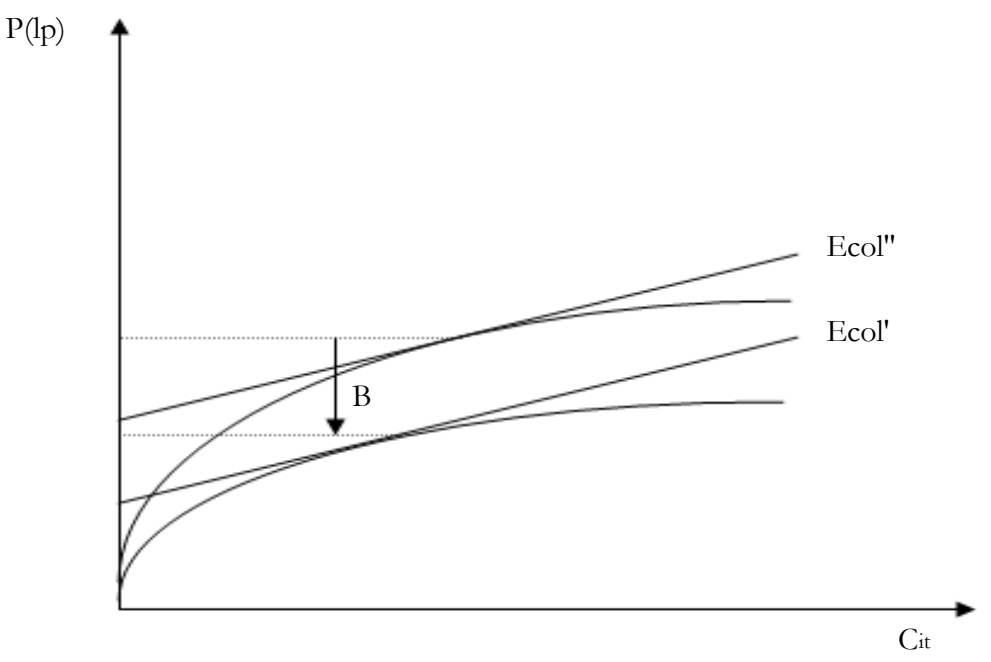

Chegamos, então, na fase de formulação do modelo ideal sobre a letalidade da ação policial. $\mathrm{O}$ modelo interacional busca responder a hipótese principal da tese de doutorado de que complexidade presente na ação policial não permite a adoção de premissas teóricas monotípicas. Acredita-se que é preciso integrar arcabouços metodológicos distintos para criar uma teoria sobre a letalidade eficiente analiticamente e sustentável logicamente. Segundo a teoria interacional, o desfecho de uma ação letal da polícia é resultado da interação entre o comportamento racional do policial condicionado, principalmente, pelo nível da atividade criminal do seu lugar de atuação, o desenho institucional e o perfil ecológico da comunidade:

$$
\mathrm{P}(\mathrm{lp})=f\left(\mathrm{C}_{\mathrm{it}}, \mathrm{SE}_{\mathrm{it}} \mathrm{I}_{\mathrm{it}}, \mathrm{E}_{\mathrm{it}}\right)
$$


A ação individual do policial não se dá no vácuo, mas sim dentro de uma rígida estrutura institucional. Essa estrutura limita o campo de ação dos atores sociais e ela própria tem seu espaço de atuação condicionado pelo contexto social em que está inserida. A ação individual dos atores sociais, portanto, é resultado da conjunção entre as preferências e as características pessoais, o perfil institucional e o contexto ecológico.

No gráfico 4 pode-se visualizar melhor o impacto das estruturas de interação na probabilidade da ação letal do policial. A curva Int" representa a situação de baixa presença de participação comunitária e instituição policial com perfil mais voltado para o conflito. Quando a interação desses fatores apresenta esse alinhamento existe uma alta probabilidade de um desfecho letal da ação do policial. A curva Int' representa a situação onde a presença de envolvimento comunitário existe lado a lado com uma instituição policial que controla a letalidade. Nesse caso, a probabilidade de uma ação policial se tornar letal é muito baixa. A seta descreve os possíveis equilíbrios segundo a teoria interacional.

Gráfico 5: efeito da interação ecologico-institucional no número de pessoas mortas pela polícia

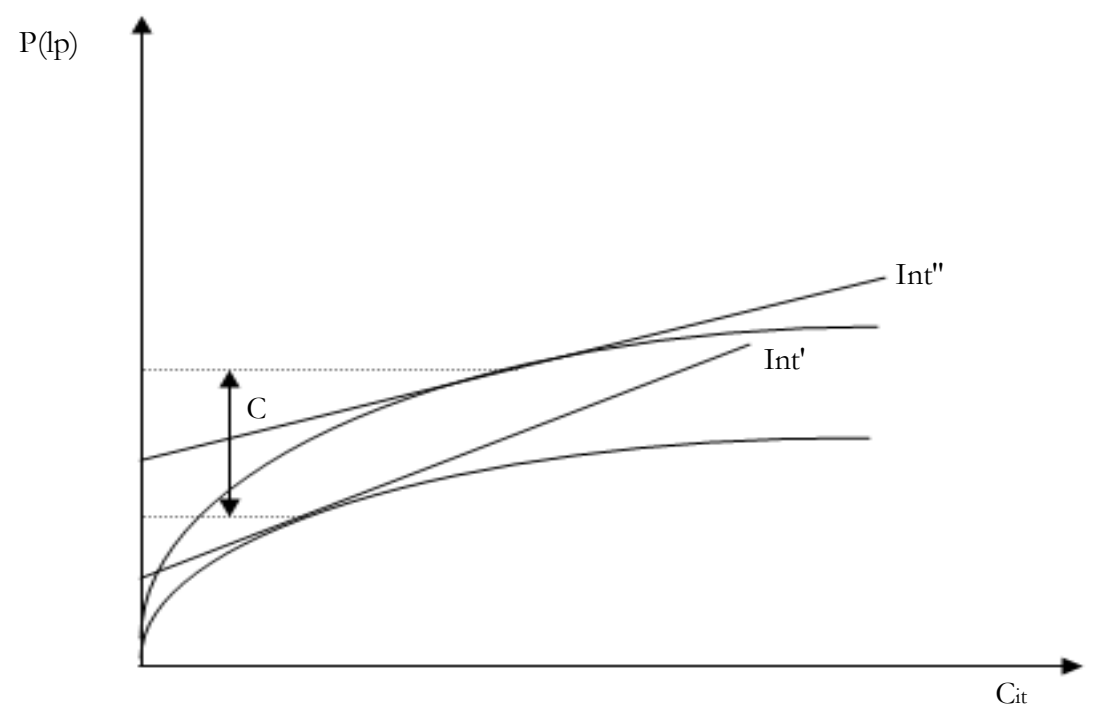


A integração de modelos teóricos, tal como proposta aqui não é nenhuma novidade (Henry e Lanier, 1998). Braithwaite (1989) integra em uma única teoria criminológica a teoria da associação diferencial (Sutherland, 1945) e teoria funcionalista de estrutura de oportunidade (Merton, 1957). Akers (1990) afirma que cálculos racionais realizados pelos atores individuais na opção pela carreira criminal, base da escola da escolha racional (Becker, 1968), estão diretamente relacionados como o processo de aprendizagem social (Akers, Krohn, Lanza-Kaduce e Radosevich, 1979). Para Laub e Sampson (1993), o comportamento criminal é resultado da combinação entre o contexto social, em que os indivíduos estão inseridos criando o ambiente necessário para o aparecimento deste tipo de comportamento, tal como proposto pela teoria do capital social (Coleman, 1987), e ausência de controles internos aos indivíduos (Gottfredson e Hirschi, 1990). Assim como Laub e Sampson, Thornberry (1987) também destaca a importância da associação entre o processo de consolidação de mecanismos individuais de controle, mas seguindo uma linha funcionalista, associa o comportamento criminal como as interações entre indivíduos e instituições sociais. Messner, Krohn e Liska (1989) consideram que há três formas principais de integração de teorias sociais: i) integração seqüencial, onde a variável dependente de uma teoria é utilizada como uma variável independente de um outro modelo teórico; ii) integração vertical, onde duas teorias são colocadas lado-a-lado para explicar algum fenômeno social e iii) integração horizontal, onde existe a combinação de diferentes níveis analíticos em um modelo teórico. Segundo os autores, a integração de modelos teóricos tende a incrementar a complexidade das teorias, já que amplia o número de variáveis independentes e adensa a teia de relações causais nos modelos teóricos.

O ceticismo de parte dos pesquisadores em relação as integrações de teóricas penológicas deve-se mais a uma postura dedutivista das ciências do que a não aceitação da necessidade patente do aumento de sofisticação das interpretações sobre o fenômeno. Para a postura dedutivista a comprovação de hipóteses implica na 
impossibilidade lógica das demais teorias (Gorski, 2004). Nesses termos, a integração entre elas não tem sentido, mesmo se isso acarretar um incremento na nossa compreensão do mundo real. No entanto, se for adotada uma visão de Ciência Social alternativa ao positivismo lógico, pode-se resolver os problemas apontados à integração de teorias sem desprezar a necessidade de serem sujeitadas a verificação empírica. Giere (1994) propõe uma redefinição da visão clássica das teorias científicas. Para o autor, elas devem ser encaradas como mapas cognitivos da realidade social. Nesse sentido, as teorias não são verdadeiras ou falsas, e sim mais ou menos similares a realidade. Granato e Scioli (2004) demonstram que concepção de teoria é compatível com os paradigmas clássicos das Ciências Sociais. Além, é claro de permitir um tratamento mais sofisticado das relações complexas presentes na realidade social, como é o caso da ação policial. Na próxima secção será demonstrado, como o processo de integração dessas dimensões analíticas é operacionalizável empiricamente.

\section{Operacionalização empírica do modelo teórico}

São grandes os desafio de operacionalizar empiricamente modelos complexos, como o proposto pela teoria interacional do comportamento policial. A hipótese interacional foi testada por meio de uma estratégia analítica de dois níveis. No primeiro momento foram construídos modelos de regressão para as hipóteses monotípica presentes na literatura sobre o comportamento policial:

$$
\mathrm{LP}=\beta_{0}+\beta C+\varepsilon \quad \varepsilon_{\mathrm{ij}} \mathrm{N} \sim\left(0, \sigma_{\mathrm{x}}\right)
$$

Onde a variável dependente do modelo de regressão é o número de mortes pela polícia durante serviço, nos 93 distrito policiais de São Paulo (Npol), $\beta_{0}$ é o vetor de valor médio esperado do número de mortos pela polícia, na situação de todos os outros vetores serem igual a zero; $\beta$ representa a matriz de coeficientes estimados das 
variáveis criminais dos distritos policiais de São Paulo (Crim) e $\varepsilon$ é o vetor de erro aleatório do modelo. Caso o modelo seja bem especificado, o erro tem distribuição normal e é independente das variáveis criminais. Tal como proposto no capítulo anterior, espera-se que o contexto criminal social em que o policial está lotado altere a probabilidade de letalidade da ação policial, apresentando efeito na letalidade policial independente do nível de crime. O modelo do contexto urbano pode ser descrito como:

$$
\mathrm{LP}=\eta_{0}+\eta \mathrm{SE}+\varepsilon \quad \varepsilon_{\mathrm{ij}} \mathrm{N} \sim\left(0, \sigma_{\mathrm{x}}\right)
$$

Onde $\eta_{0}$ é número médio esperado de morte por policiais dado o contexto socioeconômico dos distritos da cidade de São Paulo e $\eta \mathrm{SE}$ é a matrix de variáveis que mede o nível socioeconômico de cada distrito. Assim como no modelo anterior $\varepsilon$ é o vetor de erro. O teste da hipótese sobre impacto da instituição policial na letalidade policial segue a mesma estrutura dos modelos anteriores:

$$
\mathrm{LP}=\lambda_{0}+\lambda \mathrm{I}+\varepsilon \quad \varepsilon_{\mathrm{ij}} \mathrm{N} \sim\left(0, \sigma_{\mathrm{x}}\right)
$$

$\mathrm{Na}$ hipótese teórica institucionalista será introduzida um conjunto de variáveis que visam captar o efeito das instituições no comportamento racional do policial descrito em (18). Espera-se testar se $\lambda$, matriz vetor de coeficientes das variáveis institucionais agrega poder explicativo, conforme predito no modelo teórico discutido no capítulo anterior. Por fim, o último dos modelos teóricos clássicos testados será o modelo ecológico:

$$
\mathrm{LP}=\zeta_{0}+\zeta \mathrm{E}+\varepsilon \quad \varepsilon_{\mathrm{ij}} \mathrm{N} \sim\left(0, \sigma_{\mathrm{x}}\right)
$$

Onde $\zeta_{0}$ é vetor de valor médio esperado do número de morte pela polícia; $\zeta$ representa a matriz de coeficientes estimados das variáveis ecológicas (Ecol) e $\varepsilon$ é o 
vetor de erro aleatório do modelo, supostamente como distribuição normal e independente dos outros parâmetros estimados pelo modelo.

Uma alternativa para o teste da hipótese interacional seria a adoção de modelo de regressão de equação estrutural, onde as relações de causalidade entre o número de mortos pela polícia e as variáveis independentes é representada por um conjunto de equação onde cada sentença descreve as teorias paradigmáticas. $O$ teste simultâneo das equações permitiria a verificação da validade de cada hipótese quando controlada pelas hipóteses alternativas. Para utilização dessa estratégia deve-se assumir que as teorias sobre o comportamento policial são efetivamente concorrentes (Hipp e Bollen, 2003). A hipótese principal dessa pesquisa é que o comportamento policial é resultado da interação entre fatores racionais, institucionais e ecológicos. Portanto, um modelo de regressão de equação estrutural violaria o pressuposto básico da pesquisa. Adotou-se, portanto, um modelo de regressão multivariado:

$$
\mathrm{LP}=\beta_{0}+\beta \mathrm{C}+\eta \mathrm{SE}++\delta \mathrm{I}+\zeta \mathrm{E}+\lambda \mathrm{SE}+\varepsilon_{\mathrm{i}}
$$

No entanto, os testes isolados do modelo interacional especificado em (10) não comprovam automaticamente as hipóteses teóricas descritas na secção anterior. O ajuste de qualidade do modelo interacional nos dados empíricos coletados devem ser comparados aos demais modelos estatísticos. Heckman e Walker (1987) sugerem que o Teste de Qui-quadrado da Máxima Verossimilhança (Teste MV X²) é a melhor opção para conferir a qualidade de modelos quando eles são aninhados ("nested models"):

$$
\text { 2[MV X' completo - MV X } \mathrm{X}^{2} \text { aninhado] } \sim X^{2} g l
$$

$\mathrm{O}$ Teste MV $\mathrm{X}^{2}$ consiste em duas vezes a diferença entre o valor da função de máxima verossimilhança do modelo completo e do modelo aninhado. Teste MV X² 
tem uma distribuição qui-quadrado com grau de liberdade $(g l)$ igual a diferença entre número de parâmetros estimados pelos dois modelos. Para aumentar o grau de confiabilidade da análise estatística, Raftery (1995) propõe que seja verificada a qualidade dos modelos não-aninhados. Uma abordagem por discriminação com base no BIC (Bayesian Information Criterion) de cada modelo considerado tem sido a melhor solução quando os modelos em questão são não-lineares (Long, 1997):

$$
\mathrm{BIC}=\mathrm{MV} \mathrm{X} \mathrm{X}^{2}-\mathrm{pLN}(\mathrm{n})
$$

Onde p refere-se ao número de parâmetros do modelo; LN(n) é logaritmo natural do número total de observações e $\mathrm{MV} \mathrm{X}^{2}$ é valor da função de máxima verossimilhança do modelo. Quando mais baixo o valor do BIC melhor o modelo se ajusta aos dados empíricos. Raftery (1995) demonstra que além da comparação dos valores absolutos do BIC, a diferença entre os dois modelos (BICmodelo1 BICmodelo2) aumenta significativamente a qualidade do teste de ajuste dos modelos não-aninhados. Diferença próxima a zero significa que nenhum (ou ambos) dos modelos se ajustam adequadamente aos dados, diferença maior que dois significa uma ligeira vantagem do modelo 1 , diferença entre dois e seis, aumenta as evidências em favor do primeiro modelo e maior que seis não deixam dúvida em relação a escolha do modelo de regressão.

A apresentação do material empírico da tese, desenvolvido na próxima secção demonstra que a variável dependente da pesquisa não é contínua. Sendo, assim a estrutura dos dados requer a utilização de modelos de regressão para eventos de contagem (Long, 1997). Considere o Y uma variável aleatória que indica o número de vezes que um determinado evento ocorre em um intervalo de tempo e y, vetor observado para variável $\mathrm{Y}$, tem distribuição de Poisson com parâmetro $\mu>0$ tal que:

$$
\operatorname{Pr}(y \mid \mu)=\frac{\exp (\mu) \mu^{y}}{y !} \text { para } \mathrm{y}=0,1,2, \ldots \ldots \ldots
$$


Onde $\mu_{\mathrm{i}}$ é o valor médio esperado de um evento em um determinado intervalo de tempo e depende das características individuais de acordo com o modelo estrutural:

$$
\mu_{\mathrm{i}}=\mathrm{E}\left(\mathrm{y}_{\mathrm{i}} \mid \mathrm{x}_{\mathrm{i}}\right)=\exp \left(\mathrm{x}_{\mathrm{i}} \beta_{\mathrm{i}}\right)
$$

$\mathrm{O}$ modelo de regressão não-linear é definido com erro igual a $\varepsilon=\mathrm{y}-\mathrm{E}(\mathrm{y} \mid \mathrm{x})$. Quando a $\mu_{\mathrm{i}}$ é zero, os erros são heterodasticidáticos desde que $\operatorname{Var}(\varepsilon \mid x)=E(y \mid x)=\exp (x \beta)$.

Sendo que a relação entre o $\mu$ do modelo de poisson é:

$$
\mu_{\mathrm{i}}=\exp \left(\mathrm{x}_{\mathrm{i}} \beta_{\mathrm{i}}\right) \exp \left(\varepsilon_{\mathrm{i}}\right)=\mu_{\mathrm{i}} \exp \left(\varepsilon_{\mathrm{i}}\right)=\mu_{\mathrm{i}} \delta_{\mathrm{i}}
$$

Ao assumir que o $\mathrm{E}\left(\delta_{\mathrm{i}}\right)=1$, Long (1997) sugere que a variação do Modelo de Poisson:

$$
\mathrm{E}\left(\mu_{\mathrm{i}}\right)=\mathrm{E}\left(\mu_{\mathrm{i}} \delta_{\mathrm{i}}\right)=\mu_{\mathrm{i}} \mathrm{E}\left(\delta_{\mathrm{i}}\right)=\mu_{\mathrm{i}}
$$

O que permite uma aproximação linear entre $\mu$ e x quando aplica-se o antilog em (9):

$$
\log \mu_{\mathrm{i}}=\mathrm{x}_{\mathrm{i}} \beta_{\mathrm{i}}
$$

Indicando que o modelo de poisson pode ser definido com um modelo de Regressão linear tal que:

$$
\mathrm{y}_{\mathrm{i}}=\mathrm{x}_{\mathrm{i}} \beta_{\mathrm{i}}+\varepsilon_{\mathrm{i}} \quad \varepsilon_{\mathrm{ij}} \mathrm{N} \sim\left(0, \sigma_{\mathrm{x}}\right)
$$


Onde $\mathrm{y}_{\mathrm{i}}$ é o número de evento estimado para um certo período e local, $\mathrm{x}_{\mathrm{i}}$ é vetor de co-variável e $\varepsilon_{\mathrm{i}}$ é o erro de estimativa, normalmente distribuído com média zero, variância constante igual $\sigma_{\varepsilon}$ e a covariância entre $x_{i}$ e o erro seja zero (COV $\varepsilon_{i}, X$ $=0)$. A estimativa do Modelo de Regressão de Poisson é dado pela Função de Máxima Verossimilhança:

$$
L(\beta \mid y, X)=\prod_{i=1}^{N} \operatorname{Pr}\left(\left(y_{i} \mid \mu_{i}\right)=\prod_{i=1}^{N} \frac{\exp (-\mu) \mu^{y}}{y !}\right.
$$

E a mudança percentual número de evento estimado de $\mathrm{y}_{\mathrm{i}}$ dado uma variação de uma unidade de $\mathrm{x}_{\mathrm{i}}$ é:

$$
\text { (20) } \frac{\mathrm{E}\left(\mathrm{y} \mid \mathrm{x}, \mathrm{y}_{\mathrm{K}}+\varrho\right)}{\mathrm{E}\left(\mathrm{y} \mid \mathrm{x}, \mathrm{y}_{\mathrm{K}}\right)}=100 \times \frac{\mathrm{E}\left(\mathrm{y} \mid \mathrm{x}, \mathrm{y}_{\mathrm{K}}+\varrho\right)}{\mathrm{E}\left(\mathrm{y} \mid \mathrm{x}, \mathrm{y}_{\mathrm{K}}\right)}=100 \times\left[\exp \left(\beta_{k} \times \varrho\right)-1\right]
$$

Onde $\varrho$ em (13) representa a variação do número de morte pela polícia, no distrito policial de São Paulo. A transformação realizada em (13) dos coeficientes estimados em razão de chance em variação percentual facilita a interpretação dos resultados. 


\section{Capítulo 3}

\section{Descrição e identificação das variáveis}

A variável dependente da pesquisa (npol) é a letalidade de não-policiais em confronto com policiais durante o seu horário de serviço ou na sua folga, incluindo a Polícia Militar e a Polícia Civil da cidade de São Paulo. Foram utilizadas três fontes para mensurar os números de casos de letalidade de não-policiais: o banco da Comissão de Letalidade da Secretaria de Segurança Pública do Estado de São Paulo (SSP-SP), os números divulgados oficialmente pela SSP-SP e os da Ouvidoria de Polícia do Estado de São Paulo. A fonte principal foi a Comissão de Letalidade da SSP-SP, pois é possível extrair informações completas sobre casos de letalidade que são inexistentes nas outras fontes. Definiu-se os distritos que demarcam as jurisdições da Polícia Civil e da Polícia Militar de São Paulo como unidade de análise da pesquisa. A Figura 2 sobrepõe o mapa dos distritos administrativos da Prefeitura de São Paulo (linha azul) e o mapa que divide o campo de atuação de cada uma das unidades policiais da capital (linha preta). A Prefeitura divide a cidade em 96 unidades administrativas, enquanto a SSP-SP distribui suas unidades de policiamento em 93 espaços territoriais. Aparentemente, a Prefeitura busca criar uma homogeneidade socioespacial da sua distribuição administrativa e a Secretaria subdivide suas unidades por critérios técnicos. Os dados de não-policiais mortos foram agregados ao nível da jurisdição da Delegacia de Polícia (DP) onde foi registrada a ocorrência. Como todas as ocorrências de letalidade, tanto para os casos envolvendo policiais civis como policiais militares, devem ser reportadas na Delegacia de Polícia mais próxima, optouse por utilizar a distribuição espacial da Secretaria de Segurança, e não a da Prefeitura. Essa opção foi realizada para evitar problema na mensuração da variável dependente, para maximizar o poder de explicação das variáveis institucionais e pela facilidade de agregação das demais variáveis nessa unidade de análise. Resumindo, a variável dependente da pesquisa é o número de mortes de não-policiais, ocorridas nos 93 
distritos da jurisdição administrativa da SSP-SP da cidade de São Paulo, entre os anos de 2001 e 2003 (npol).

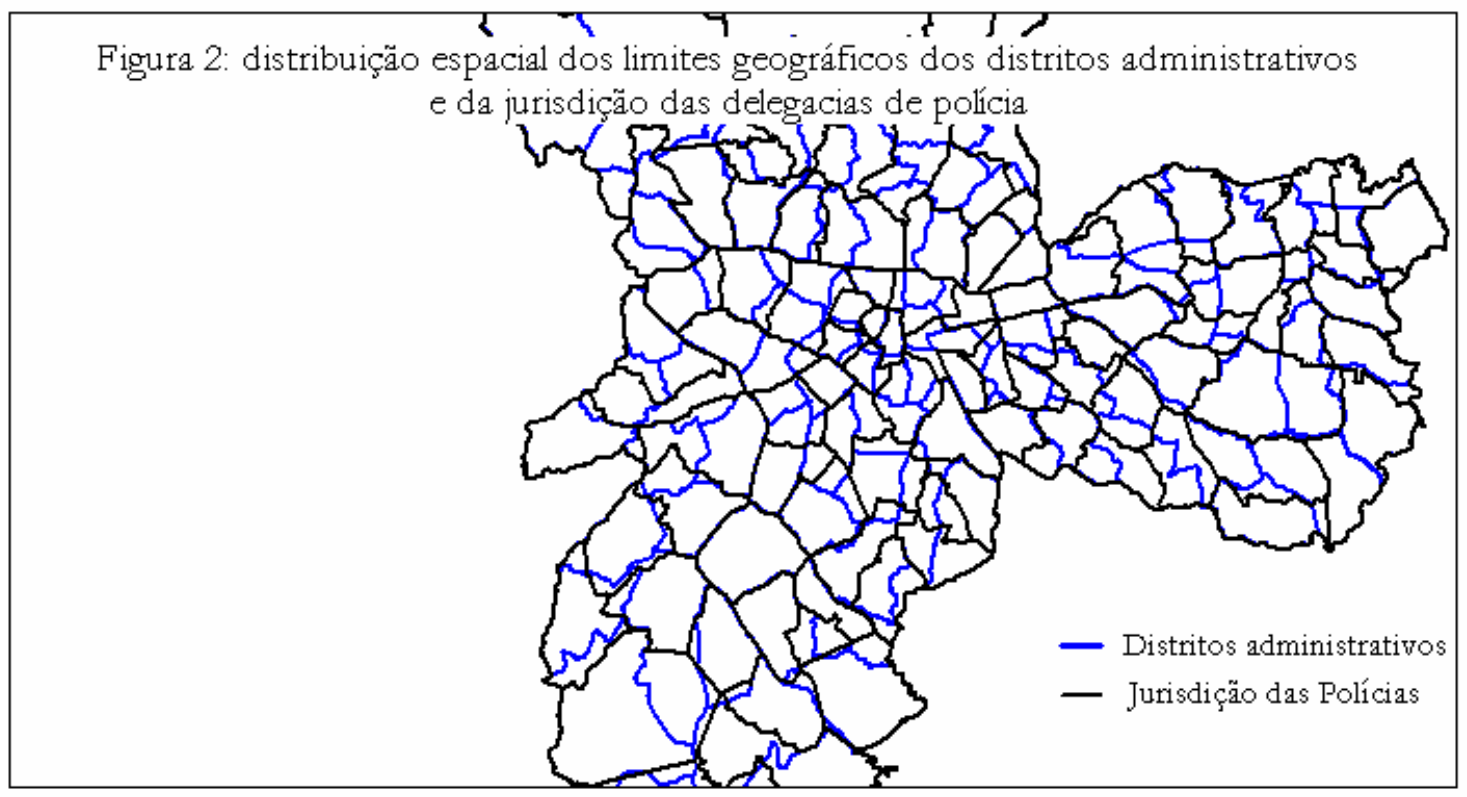

O Gráfico 6 demonstra uma pequena diferença entre a quantidade de casos presentes no banco da Comissão de Letalidade, os divulgados pela SSP-SP e os dados da Ouvidoria de Polícia. Em 2001, 274 casos de letalidade de não-policiais constam no banco da Comissão de Letalidade, 250 casos foram divulgados oficialmente pela SSP-SP e segundo a Ouvidoria foram mortas pela polícia 278 pessoas. A SSP-SP não deixa especificado se somente estão computados as ocorrências de letalidade em serviço ou se os casos durante a folga dos policiais fazem parte do banco. Já a Ouvidoria apresenta essa informação, mas não justificativa porque há a diferença no número de casos de letalidade divulgado por esse órgão e pela Secretaria. No banco de dados da Comissão de Letalidade estão computados os casos de letalidade que ocorreram durante o horário de serviço e de folga do policial. Isso explica o número de mortes no banco de dados da Comissão de Letalidade ser 33,60\% maior do que o divulgado pela SSP-SP, mas não explica a diferença de $20 \%$ em relação aos dados da Ouvidoria. 
Em 2002, a Secretaria divulgou que na cidade de São Paulo foram mortas 306 pessoas em confronto com policiais, segundo a Ouvidoria o número de mortes em confronto é de 297 e no banco da Comissão de Letalidade foram identificados 369 casos de pessoas mortas por policiais. Novamente, não temos informações se os dados divulgados pela Secretaria de Segurança Pública do Estado de São Paulo levaram em consideração as ocorrências durante a folga e o período de serviço do policial. Para o ano, a banco apresenta 20,40\% mais casos do que a SSP-SP e $24,24 \%$ do que divulgado pela Ouvidoria.

No ano 2003, a discrepância entre as fontes ficou mais acentuada. A SSP-SP divulgou a existência de 519 pessoas mortas em confronto com policiais na capital paulista. Diferentemente dos anos precedentes, a Secretaria discriminou os casos ocorridos durante o serviço e no período de folga dos policiais. Foram divulgados 443 casos de letalidade durante o serviço do policial e 76 casos de mortes durante a folga. A Ouvidoria, neste ano, publicou somente o número de mortes cometidas por policiais que foram denunciados no órgão. Não está claro se trata ou não de todos os casos, ocorridos no ano, nem se são apenas os casos que aconteceram durante o serviço do policial. No banco de dados foram identificadas 396 ocorrências. O número de casos é 25,70\% menor do que o registrado pela SSP-SP e 2,10\% maior do que apontado pela Ouvidoria. O número de casos presentes no banco de dados da Comissão de Letalidade é menor que o real, pois desde meados de novembro e até o final de dezembro de 2003 não houve preenchimento de banco por motivos burocráticos. Como não existem evidências de que a interrupção da coleta de dado no período tenha distorcido as informações sobre a distribuição de letalidade nos distritos de São Paulo, foi estimado o número de caso do período segundo o padrão dos anos anteriores. 


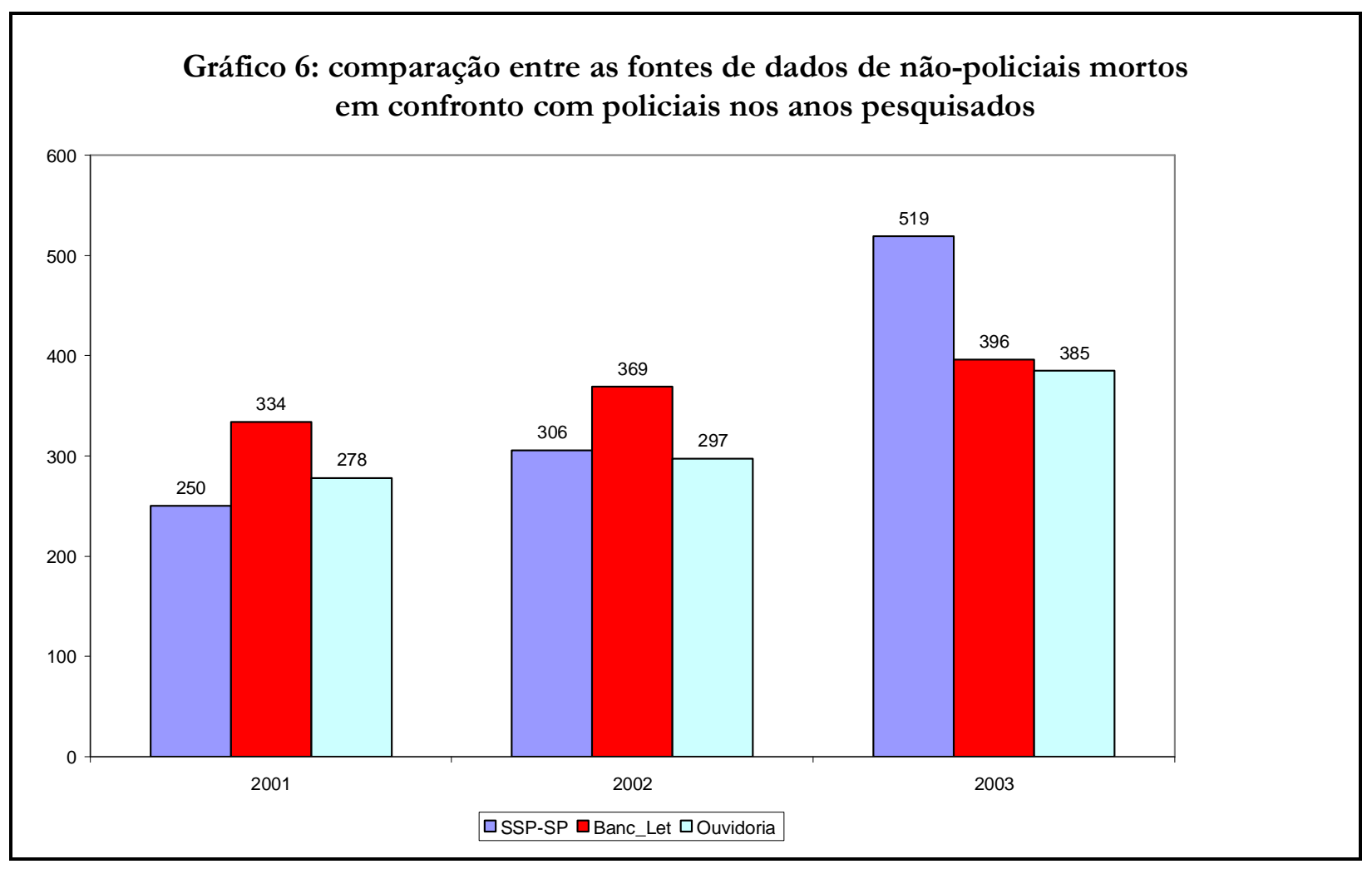

O gráfico 7 compara as três fontes de dados de letalidade, levando em conta apenas os casos de letalidade ocorridos durante o serviço do policial envolvido em confronto e o número de caso de letalidade estimado para o ano de 2003. Se forem consideradas as informações de letalidade divulgadas pela SSP-SP, como as ocorrências durante o serviço do policial, o número de casos de mortes por policiais na cidade de São Paulo é 8\% menor no banco da Comissão e 28,49\% maior em relação ao publicado pela Ouvidoria. Foram identificados 230 casos de letalidade durante o horário de serviço de polícia, em 2001, o banco da Comissão e o da Ouvidoria divulgou 179 casos. Em 2002, no banco da Comissão foram encontrados 270 casos de letalidade em serviço, a Ouvidoria de Polícia divulgou que existiram 205 ocorrências de mortes de pessoas em confronto com policiais em serviço. Para a Secretaria existiram outras 36 mortes que não são encontradas no banco de dados da Comissão. Na Ouvidoria, para ano de 2003, não foi registrada nenhuma informação sobre os casos de letalidade durante o serviço do policial. A diferença entre o valor estimado no banco de dado da Comissão e o divulgado pela Secretaria de Segurança 
Pública é de 34,50\%. No banco da Comissão, foram estimados 334 casos de letalidade quando o policial estava em serviço e a Secretaria divulga a existência de 443 ocorrências desse tipo.

As evidências reunidas e apresentadas nessa secção atestam a qualidade das informações contidas no banco de dados da Comissão de Letalidade que será utilizado como principal fonte primária sobre o padrão de morte pela polícia na cidade de São Paulo. A hipótese interacional do comportamento policial não impõe restrições ao determinante da letalidade policial. Ou seja, o modelo teórico defendido não prediz que as mortes que acontecem fora do serviço do policial e durante sua atividade profissional de rotina estejam correlacionadas a diferentes ordens de fatores. Mesmo, as mortes ilegais, como aquela por grupo de extermínio, estarão, segundo a teoria, relacionadas às dimensões sociais similares às mortes legais e legítimas. Face a isso, optou-se por utilizar todas as informações presentes no banco da Comissão de Letalidade, sem diferenciar se o policial estava ou não em serviço no momento do confronto que gerou a morte dos não-policiais.

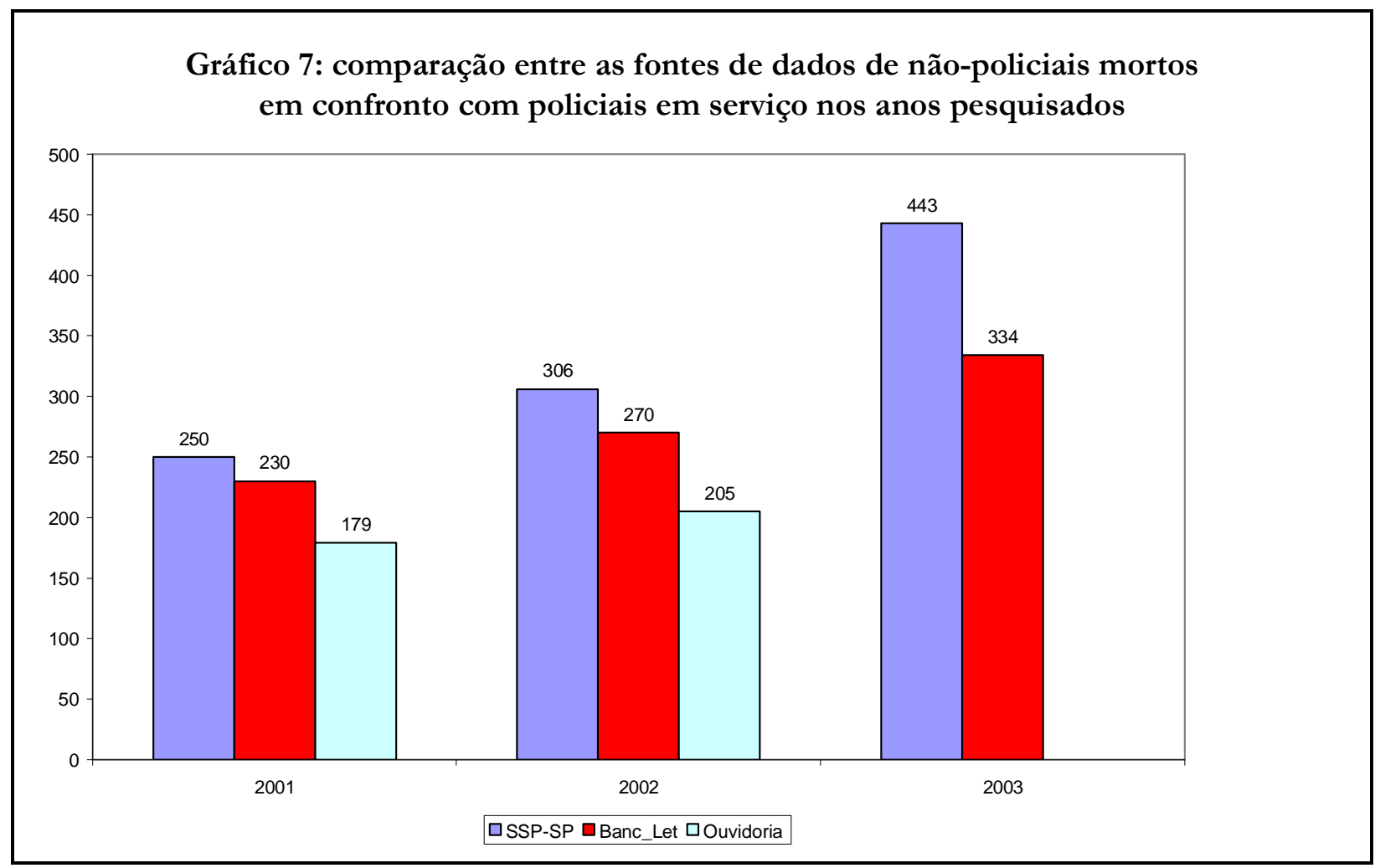


A tabela 1 apresenta as estatísticas descritivas do número de mortes por policiais na cidade de São Paulo. No ano de 2001, dez distritos não tiveram caso de letalidade, 43 deles apresentaram de um a três casos, em 20 distritos houve de quatro a seis mortes pela polícia, em 13 os policiais mataram entre seis e oito pessoas e em sete distritos, a polícia foi responsáveis por mais de oito mortes. O distrito mais violento do ano foi Jardins da Imbuais, localizado na zona sul da cidade de São Paulo, com 15 mortes. O desvio-padrão do ano foi de 3,15 mortes de não-policiais, a média da cidade foi 3,59 e a mediana foi três casos de letalidade.

No ano de 2002, 369 pessoas perderam a vida em confrontos com policiais, a média da cidade foi 3,98 casos de letalidade por distrito e a mediana foi de três mortes. Em 12 distritos não existiu nenhum caso de letalidade no período, em 38 deles até três pessoas foram mortas em confronto com a polícia. Em 16 distritos a polícia foi responsável por mais de quatro mortes e menos de seis. Em quatorze distritos os confrontos entre policiais e não-policiais provocaram de seis a oito mortes entre o segundo grupo e em 16 distritos os policiais assassinaram mais de oito pessoas. A violência da polícia atravessa a cidade, o distrito mais violento do ano fica na região Norte. No distrito do Jaçanã, 14 pessoas foram mortas pela polícia em um único ano, sendo que o distrito já aparecia como um dos mais violentos no ano anterior com 14 casos de letalidade. O Jardim das Imbuias reduziu drasticamente os caos de letalidade de um ano para outro, passando a ter cinco casos de letalidade em 2002.

Novamente, o distrito do Jaçanã aparece com o mais letal da cidade, em 2003, com 16 mortes de não-policiais em confronto com a polícia. No período, a cidade teve 474 casos de letalidade, um incremento de $22,15 \%$ em relação ao ano anterior. A média da cidade foi de 4,22 casos de letalidade por distrito e a mediana foi de quatro casos. Em 12 distritos não foi registrado episódio de morte de não-policiais em confronto com a polícia e em 20 existiram de um a três casos de letalidade. Vinte e quatro distritos apresentaram de quatro a seis letalidades e em 21 , cerca de, seis e oito 
pessoas perderam a vida em confronto com a polícia. Em 16 distritos, a polícia apresentou um padrão exacerbado de letalidade, totalizando mais de oito mortes.

Os mapas 1 a 5, no anexo, ajudam a visualizar a distribuição do número de morte pela polícia na cidade de São Paulo. O mapa 1 apresenta a distribuição das mortes para em 2002, o mapa 2 para o ano de 2002 e o mapa 3 para o ano de 2003. Os três mapas têm um mesmo padrão, quanto mais marrom o distrito, maior a incidência de casos de letalidade. Os distritos com cores mais próximas à cor cinza são distritos com menor número de casos de letalidade. A divisão das categorias segue o molde exibido na tabela 1 . O mapa 4 apresenta a divisão do distrito, segundo a seccional de polícia. Uma discussão sobre a importância de seccional de polícia será empreendida na próxima secção. O mapa 5 exibe a identificação dos distritos e a tabela 19 do anexo contém informações individualizadas para todos eles. Nesta tabela é possível encontrar o número de morte pela polícia para cada distrito, nos três anos que compõe a amostra da pesquisa. São apresentadas, ainda, a média do período, o desvio-padrão, o nome do distrito e a seccional de polícia que o ele integra.

\begin{tabular}{lcccc}
\hline \multicolumn{5}{l}{ Tabela 1: estatísticas descritivas da variável dependente } \\
\hline Nenhuma & 2001 & 2002 & 2003 & Total \\
Entre 1 e 3 & 10 & 12 & 12 & 34 \\
Entre 4 e 6 & 43 & 38 & 20 & 101 \\
Entre 6 e 8 & 20 & 16 & 24 & 60 \\
Mais de 8 & 13 & 14 & 21 & 48 \\
Média & 7 & 13 & 16 & 36 \\
Mediana & 3,59 & 3,98 & 5,10 & 4,22 \\
DP & 3 & 3 & 5 & 4 \\
Máximo & 3,15 & 3,49 & 3,82 & 3,54 \\
Mais Violento & J. Imbuias & Jaçanã & Jaçanã & 16 \\
Total & 334 & 369 & 474 & \\
N & 93 & 93 & 93 & 279 \\
\hline
\end{tabular}




\section{Variáveis independentes}

As variáveis independentes dos estudos estão divididas em quatro blocos. $\mathrm{O}$ primeiro grupo de variável tenta captar o efeito da dinâmica criminal na probabilidade do desfecho letal da ação policial (dimensão situacional). O segundo bloco visa explorar a relação entre o contexto socioeconômico do lugar de atuação do policial e a letalidade (dimensão contextual). No terceiro bloco, busca-se dimensionar o impacto dos constrangimentos institucionais no recurso da letalidade (dimensão institucional). Por fim, o quarto bloco de variável independente capta o efeito da estrutura de relações sociais presente nos distritos de São Paulo (dimensão ecológica). A hipótese interacional que aponta a existência de uma integração entre os fatores associados aos modelos anteriores explica a probabilidade de uma ação policial ter um desfecho letal.

\section{Variáveis situacionais}

As variáveis criminais analisadas foram: 1) ocorrência de homicídios dolosos, ato de matar alguém deliberadamente (hom_dol); 2) ocorrências de roubo consumado, ato de subtrair coisa alheia, mediante grave ameaça ou violência contra a pessoa, ou depois de havê-la, por qualquer meio, reduzido à impossibilidade de resistência (roub); 3) ocorrência de roubo de veículo consumado (roub_vei); 4) ocorrência de latrocínio, roubo seguido de morte da vítima (latr); 5) ocorrência de seqüestro, ato de privar a liberdade alheia com fins deliberados de obter vantagens financeiras (seq); 6) ocorrência de furto consumado, ato de subtrair bem alheio, sem grave ameaça ou violência contra a pessoa (furt); 7) ocorrência de furto de veículo (furt_vei); 8) apreensão de arma de fogo ilegal (arm_fog); 9) ocorrência de tráfico de maconha (traf_mac); 10) ocorrência de tráfico de cocaína (traf_coc); 11) total das ocorrências policiais registradas nos distritos policiais (oco_pol); 12) inquéritos instaurados a partir das ocorrências registradas (inq_inst). Os dados para cada um dos 
anos e para os 93 distritos policiais que compõem a amostra foram recolhidos junto a Fundação Sistema Estadual de Análise de Dados - Seade e a Secretaria de Segurança Pública do Estado de São Paulo.

Foi aplicado um modelo estatístico de análise de componentes principais (ACP) para reduzir indicadores criminais em um conjunto de variável menor, mas que mantivesse o máximo de informação do conjunto original. Utilizou-se o critério de Kaiser, que propõe a manutenção dos autovalores acima de um e o critério de manutenção dos fatores que são interpretáveis teoricamente para definir os números a serem retidos em cada modelo de ACP. Utilizando rotação Varimax, que evita a correlação entre os fatores e aumenta o poder explicativo dos modelos, descobriu-se que os dados criminais estão distribuídos em quatro dimensões latentes ou fatores. Os gráficos 8 a 10 apresentam as relações entre os fatores estimados pelo modelo e as dimensões criminais observadas na realidade. O círculo vermelho representa graficamente a nova variável.

O gráfico 8 demonstra que o primeiro fator está associado aos crimes contra a vida (crim_vio). A Análise de Componentes Principais descreve, também, a forte associação da distribuição do homicídio doloso em São Paulo, da apreensão de armas de fogo, do seqüestro e do latrocínio. O roubo de veículo aparece como fortemente associado aos crimes violentos. O fator responde por $24,68 \%$ da variabilidade da amostra.

O segundo fator, apresentado no gráfico 9, responde por $23,39 \%$ da variabilidade da amostra e está relacionado ao crime de furto, roubo e furto de veículos (crim_patr). Trata-se de crime com menor grau de violência, já que o contato entre vítima e agressor é menos provável. Menos, para o roubo, cujo contato existe. O fator representa, ainda, o nível de atividade da polícia judiciária. Está documentado na literatura de vitimização que os crimes com menor potencial agressivo, como os furtos, arrombamento e pequenos roubos são menos sujeitos de serem reportados para a polícia do que os crimes mais violentos, como roubo de grandes quantias, homicídios, seqüestros e latrocínios. Os únicos crimes de baixo potencial ofensivo 
para vítima que são altamente reportados para a polícia são os furtos de veículos, que na maioria das vezes precisa do boletim de ocorrência emitido pela polícia civil para a entrada no seguro. Além, é claro, do fato que um carro não pode ser considerado um bem de baixo valor. Em relação aos crimes violentos, o problema de subnotificação concentra-se nos crimes sexuais, tais como atentado violento ao pudor, estupros e pedofilias, onde a vítima por medo, trauma ou por receios sociais tende a não notificar a polícia (Carneiro, 1999). A concentração das variáveis relacionadas ao crime contra o patrimônio confirma as evidências encontradas em trabalhos anteriores de que a distribuição desse tipo de crime está mais associada ao desempenho das instituições policiais do que propriamente a correlação direta com os crimes violentos.

O último fator extraído da APC nas variáveis situacionais é apresentado no gráfico 10. O terceiro fator representa $17,40 \%$ da variabilidade da amostra e está correlacionado com crime de tráfico de drogas (crim_drog), tais como tráfico de maconha e cocaína. A impressão inicial do que os crimes violentos e crimes de drogas compartilhavam o mesmo contexto urbano não está respalda pelas evidências empíricas. O comércio de droga apresenta uma dinâmica própria, ora mais próximo dos nichos de crime contra patrimônio ora interagindo com os crimes violentos. $\mathrm{O}$ tráfico de entorpecente assume característica semelhantes aos crimes de patrimônios, tais como a necessidade da concentração de pessoas com alto potencial financeiro que pode significar uma clientela disponível ao consumo. Outra similitude entre as duas atividades criminais é a centralidade do sistema policial para determinar a presença desse crime. As partes envolvidas nas atividades raramente reportam a polícia o crime e sendo assim, toda notificação do crime está diretamente relacionado como o nível de atividade policial da área. A alta notificação de crime de tráfico pode estar mais associada com uma polícia que apreende constantemente os traficantes do que propriamente a presença intensa do comércio de substância ilegal na área. No entanto, os crimes de tráfico de entorpecente, também, estão diretamente ligados aos crimes violentos. O tráfico é uma atividade altamente perigosa e sem regulamentação 
estatal. O homicídio, nesse sentido, é um elemento central na manutenção ou da abertura de ponto de tráfico. Outra dimensão importante que liga o tráfico aos crimes violentos é a clientela, que sob o efeito das substâncias ilícitas tendem a provocar mais violências ou praticar delitos economicamente motivado para sustentar o consumo. Portanto, não é de surpreender a presença de uma dimensão específica para os crimes de droga na estratégia de análise multivariado dos dados criminais.

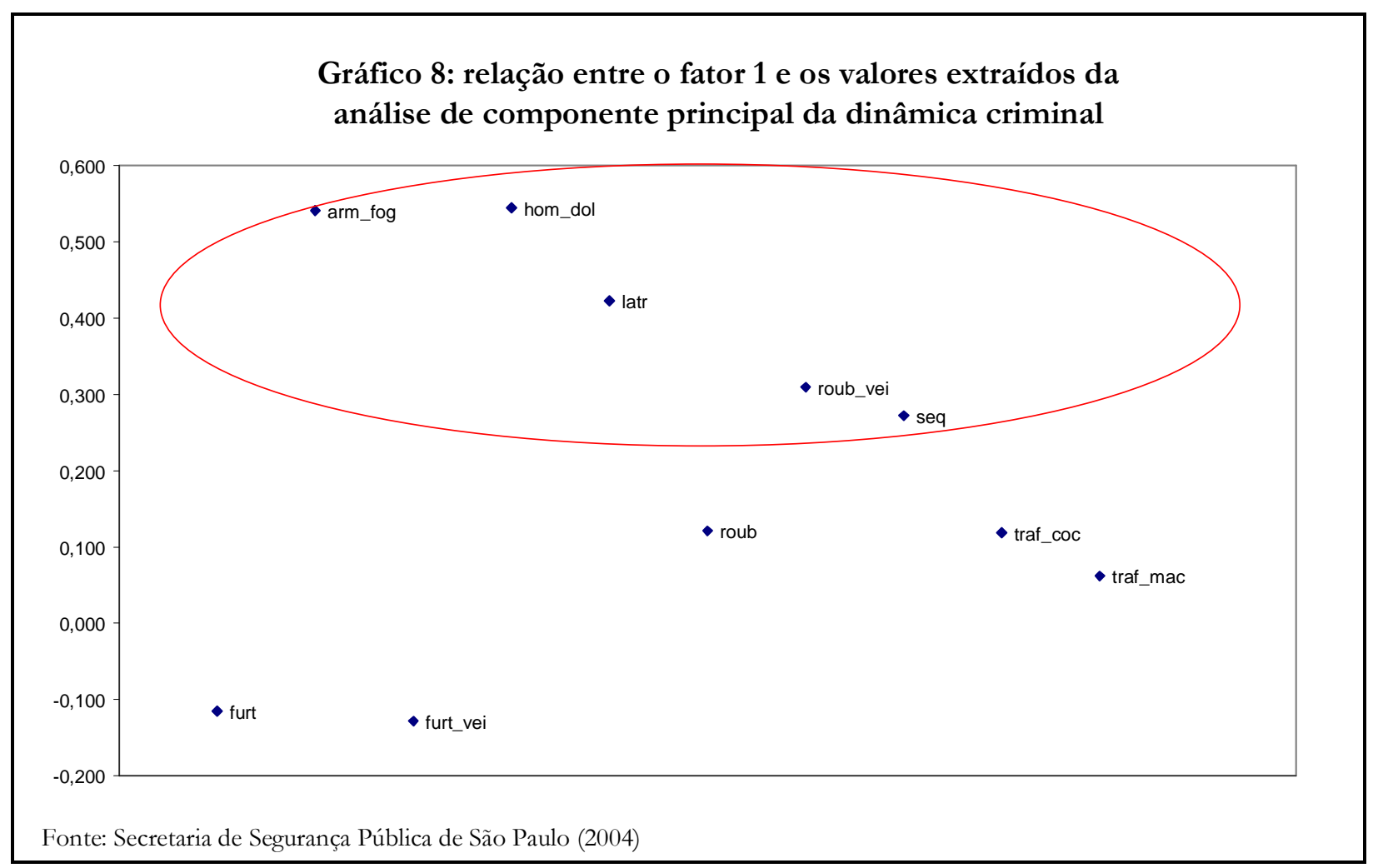




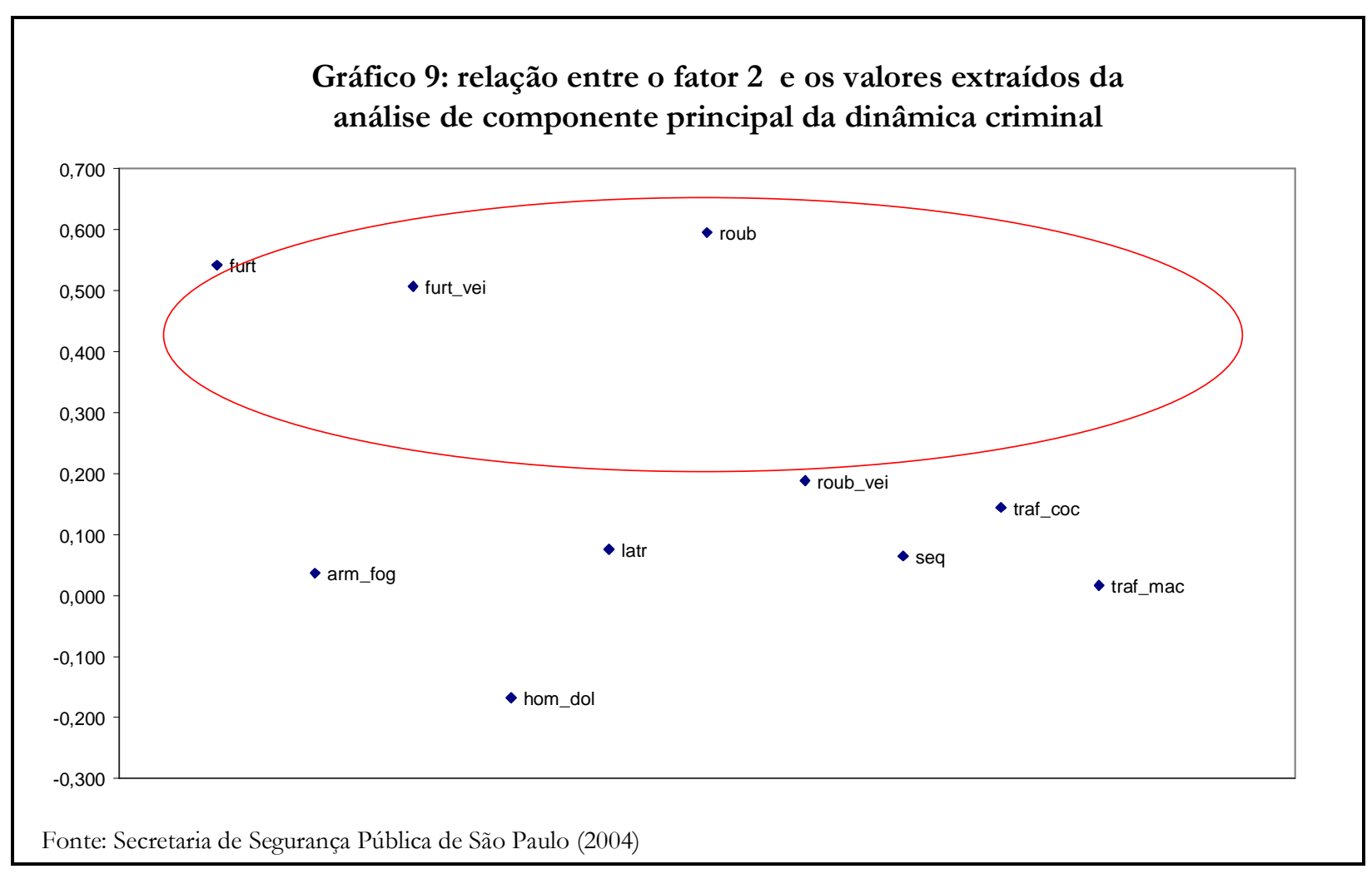




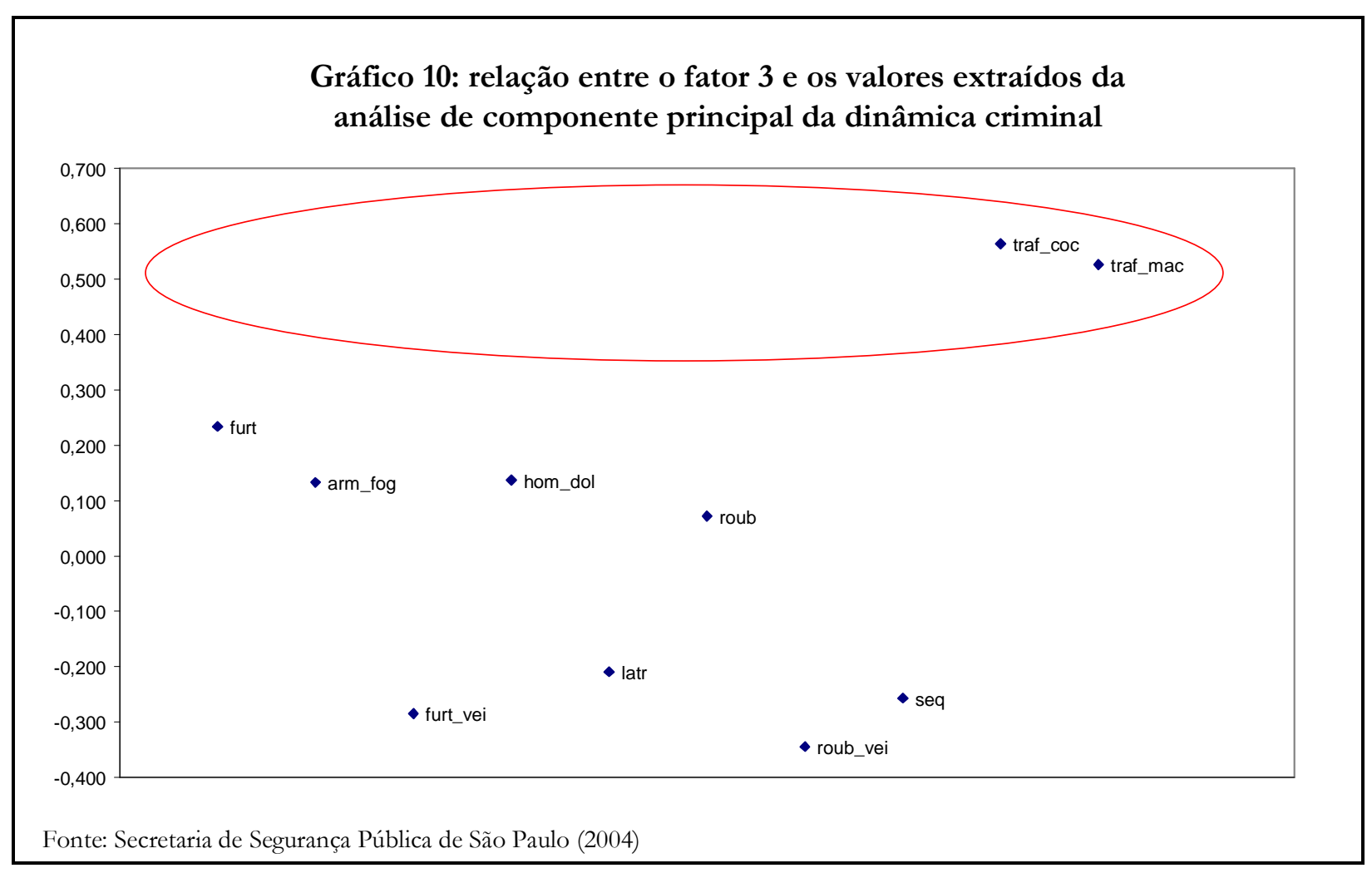

\section{Variáveis contextuais}

Não existe um claro consenso na literatura especializada sobre as varáveis mais bem indicadas para descrever o contexto urbano. Torres, Marques, Ferreira, e Bitter (2003) alertam para múltiplas formas para a definição de pobreza e exclusão social nas metrópoles urbanas brasileiras. Processos urbanos, econômicos e sociais interagem de maneira complexa na cidade de São Paulo, impossibilitando a adoção de uma única variável que exponha adequadamente os mecanismos sociais que separam as camadas mais pobres das camadas mais ricas. Torres e colaboradores (2003) sugerem o emprego de técnicas mais sofisticadas de construção de indicadores socioeconômicos eficientes. Nesse sentido, tal como realizado para o caso das variáveis criminais, foi empregada análise de componente principal (APC) para manejar o máximo possível de informação socioeconômica sobre os distritos da capital paulista. O critério de retenção dos componentes foi similar a APC realizada no conjunto de variáveis criminais. 
As variáveis socioeconômicas incluídas foram: 1) porcentagem, no distrito da capital paulista, de chefes (homens ou mulheres) responsáveis pelo domićlio e que ganham mais de 10 salários mínimos (renda); 2) densidade demográfica, (dens_pop); 3) taxa anual de crescimento populacional entre 1991 e 2000 (cresc_pop); 4) participação dos jovens, de 15 a 19 anos, no total da população dos distritos (prop_jov_dist); 5) participação dos jovens, de 15 a 19 anos, no total de jovens do município (prop_jov_dist); 6) proporção de mães adolescentes, de 14 a 17 anos, no total de nascidos vivos (mãe_adol); 7) taxa de fecundidade das adolescentes de 14 a 17 anos (fecund); 8) proporção de jovens, de 18 a 19 anos, que não concluíram o ensino fundamental (ens_incomp); 9) proporção de jovens, de 15 a 17 anos, que não freqüenta à escola (não_esc); 10) proporção de pessoas que mudaram nos últimos 5 anos para a atual residência (fluxo); 11) área total de favela nos distritos da capital (fav) e 12) proporção da área dos distritos ocupada por favela. As fontes para as variáveis foram a Fundação Seade, o Centro de Estudo da Metrópole (CEBRAP) e Fundação IBGE.

Os indicadores socioeconômicos, inicialmente, foram coletados para os distritos administrativos da Prefeitura de São Paulo, sua identificação, a distribuição espacial dos distritos da Secretaria de Segurança Pública, unidade de análise da pesquisa, foi realizada por meio da derivação espacial com o auxílio do Programa de Georeferenciamento Mapinfo. A técnica consiste na justaposição de dois planos cartográficos, assume-se que a distribuição dos indicadores é homogênea no espaço e deriva a média ponderada do indicador nas áreas de intersecção entre os dois planos. A figura 2 ajuda a visualizar os dois planos cartográficos, a técnica consiste em estimar as informações contidas nos limites definidos pela linha azul (distritos da Prefeitura) para a área delimitada pela linha preta (distritos da SSP-SP). Os resultados da técnica foram validados com a aplicação do mesmo procedimento para os dados criminais. Os dados criminais foram escolhidos como instrumento de validação porque existia informação para as duas distribuições espaciais. A correlação dos dados estimados 
pelo processo de derivação espacial e com as séries originais foi de cerca de $95 \%$ para todos os indicadores criminais.

Os gráficos abaixo auxiliam na visualização dos construtos teóricos resultantes da ACP. O gráfico 11 descreve a associação das variáveis introduzidas no modelo e o primeiro fator extraído. O primeiro componente responde por 50,95\% da variabilidade da amostra e, como é possível ver no gráfico 12 , está claramente associado a desorganização social. O segundo componente responde por 17,83\% da variabilidade da amostra e está associado à desorganização física do distrito, conforme pode ser verificado no gráfico 13. O terceiro componente está associado, em menor intensidade, ao nível de renda médio do distrito e, em maior grau, à instabilidade populacional representada pela presença de moradores recentes e à alta densidade populacional. Isso sugere uma maior preponderância dos aspectos financeiros no componente, que responde por $13,12 \%$ da variabilidade da amostra.

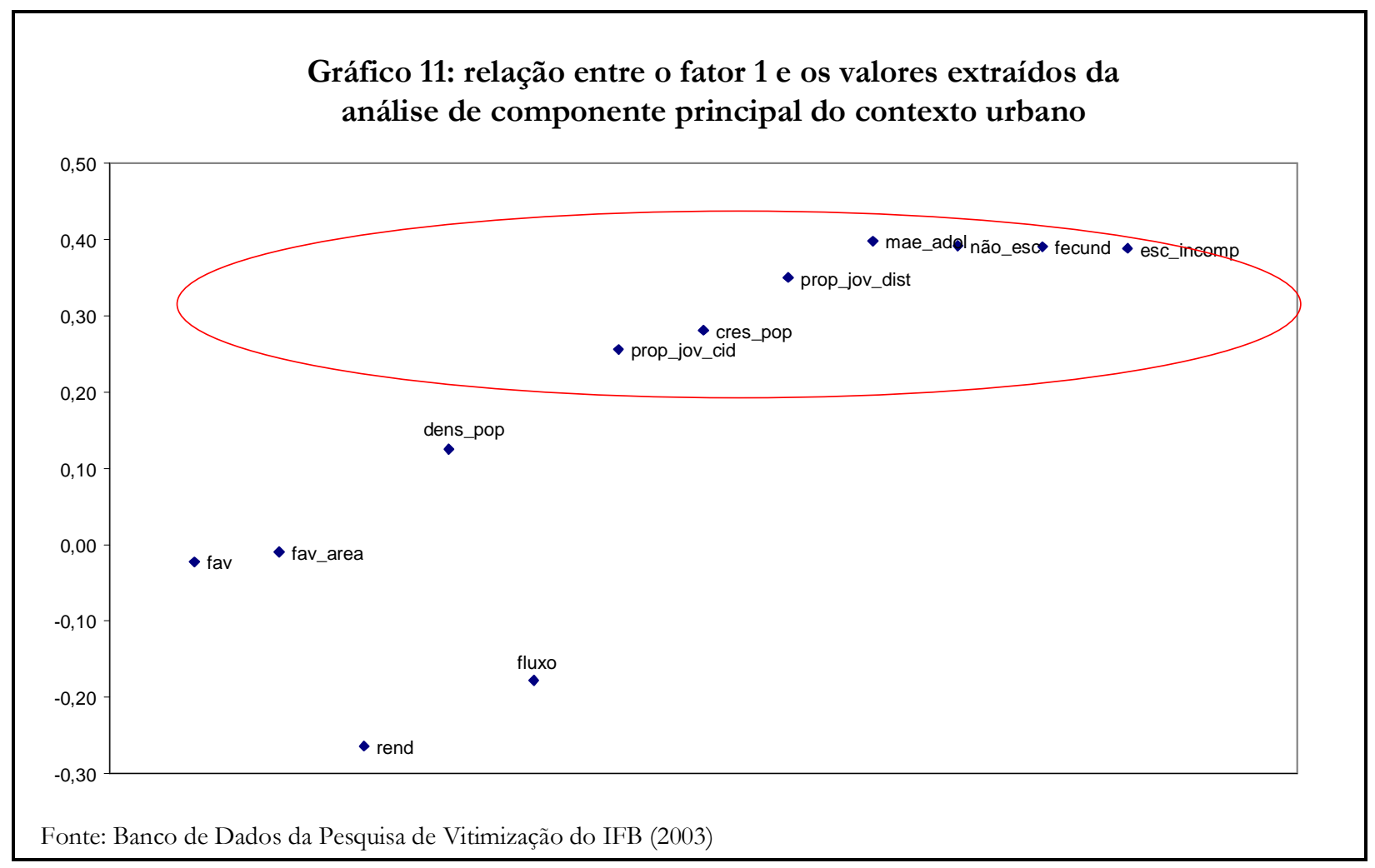



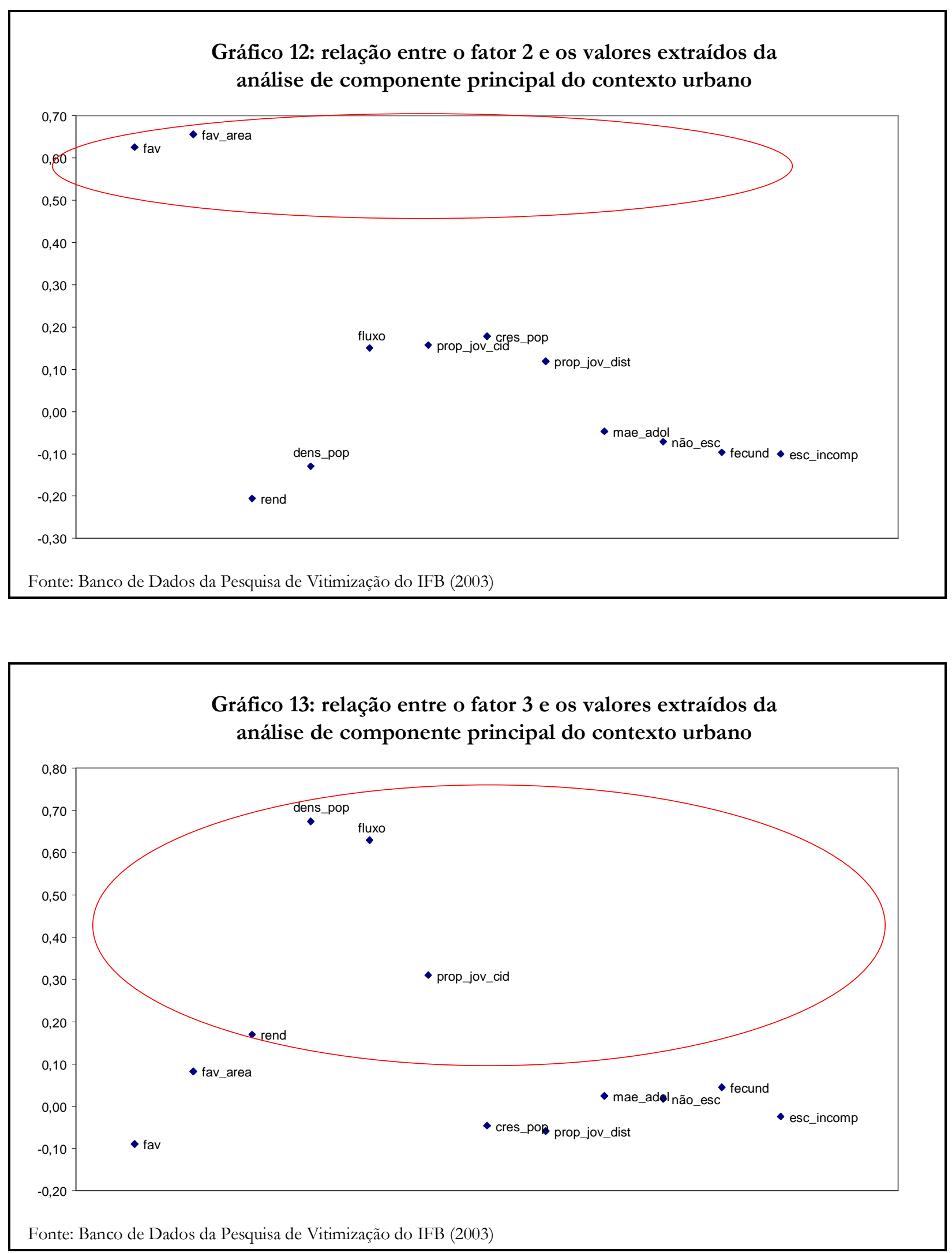


\section{Variáveis institucionais}

A definição das variáveis institucionais está instrumentalmente associada ao perfil do secretário de Segurança Pública (secr) e ao perfil dos comandantes de área da Polícia Militar e da Polícia Civil (secc). Devido às características inerentes a todas instituições policiais, tais como presença de hierarquia, mecanismos de sanção para os casos desviantes, tentativa social, política e administrativa de redução do poder discricionário do policial, principalmente da utilização da força física, podemos supor que o controle das lideranças organizacionais é pronunciado. Análises preliminares demonstram a consistência da opção por um modelo parcimonioso sobre o impacto das variáveis institucionais no controle do comportamento policial.

$\mathrm{Na}$ tabela 2 é apresentado um modelo de análise de variância (ANOVA) que explora as diferenças médias no número de morte de não-policiais das várias administrações da Secretaria de Segurança Pública do Estado de São Paulo. Cerca de 90\% da variância do número de mortes de não-policiais está associada à mudança de secretário de Segurança. As administrações que compõem a amostra de pesquisa têm uma diferença média estimada de 124 mortes (casela marcada). Foi criada uma variável qualitativa, para a administração do secretário Saulo de Abreu, cujo discurso belicoso de combate ao crime era mais intenso, e para administração do secretário Petrelluzi, na qual o controle da letalidade da ação policial era mais intenso, para testar o efeito das dinâmicas institucionais no comportamento policial em São Paulo. 
Tabela 2: Resultado de ANOVA para as diferenças do número de letalidade de não-policiais nas administrações da Secretaria de Segurança Pública do Estado de São Paulo, nos últimos 20 anos

Fleury Afonso Mariz $\begin{gathered}\text { Muylaer Pinto Campos Petrelluz } \\ \mathrm{t}\end{gathered}$

\begin{tabular}{lcccccccccc} 
Afonso & 131 & & & & & & & & \\
Mariz & 217 & 88 & & & & & & & \\
Muylaert & 22 & -109 & -195 & & & & & \\
Pinto & 193 & 62 & -24 & 171,00 & & & & \\
Campos & $896^{*}$ & $761^{*}$ & $675^{*}$ & $870,5^{*}$ & $699^{*}$ & & & & \\
Petrolluzi & $353^{*}$ & 222 & 136 & 331,00 & 160 & $-539^{*}$ & & & \\
Pimentel & -49, & -180 & -266 & $-71,00$ & -242 & -941 & -402 & & \\
Saulo & $477^{*}$ & $346^{*}$ & 260 & $455,20^{*}$ & 284 & $-415^{*}$ & 124,20 & $526^{*}$ & \\
Temer & 121 & -11 & -96 & 98,67 & -72 & $-772^{*}$ & -232 & 170 & $-357^{*}$ \\
\hline $\mathrm{F}=14,25^{*}$ & & & & & & & & & \\
$\mathrm{R}^{2}=90,15$ & & & & & & & & & \\
$* \mathrm{P}>0,05$ & & & & & & & & & \\
\hline
\end{tabular}

A cidade de São Paulo está dividida pela SSP-SP em oito grandes regiões administrativas, que englobam a subdivisão dos 93 distritos policiais. Cada área é policiada conjuntamente por um Comando Territorial da Polícia Militar e por um Comando da Polícia Civil. Como são os comandantes de área os responsáveis pela implementação das diretrizes da política da segurança do Estado, trata-se de um fórum privilegiado para estudar o efeito dos fatores institucionais no comportamento do policial. Foram criadas variáveis qualitativas que captam o efeito de cada uma das dinâmicas institucionais ao nível de comando de área sobre a letalidade da ação policial. A tabela 3 apresenta o modelo da análise de variância para as diferentes regiões administrativas da SSP-SP. A análise preliminar foi realizada já com os dados finais da tese de doutorado. Os resultados demonstram que $16,43 \%$ da variabilidade do número de não-policiais mortos está associada ao comando de área da polícia. 
Tabela 3: Resultado de ANOVA para as diferenças do número de letalidade de nãopoliciais nas jurisdições das 8 Comandos de Área de São Paulo

\begin{tabular}{lrrrrrrr}
\hline & Centro & Sul & Oeste & Norte & Leste & S. Amaro & Itaquera \\
Sul & 0,70 & & & & & & \\
Oeste & 0,81 & 0,11 & & & & & \\
Norte & $2,44^{*}$ & $1,74^{*}$ & $1,63^{*}$ & & & & \\
Leste & 0,08 & $-0,62$ & $-0,73$ & $-2,36^{*}$ & & & \\
S. Amaro & 1,99 & 1,29 & 1,18 & $-0,46$ & $1,90^{*}$ & & \\
Itaquera & 0,92 & 0,22 & 0,11 & $-1,53$ & 0,83 & $-1,07$ & \\
S. Matheus & 2,24 & 1,54 & 1,43 & $-0,20$ & 2,16 & 0,25 & 1,32 \\
\hline $\mathrm{F}=7,61^{*}$ & & & & & & & \\
$\mathrm{R}^{2}=16,43$ & & & & & & & \\
$* \mathrm{P}>0,05$ & & & & & & & \\
\hline
\end{tabular}

\section{Variáveis ecológicas}

As definições das variáveis ecológicas e as estratégias de mensuração dos mecanismos causais que ligam sua presença ao desempenho institucional não estão consolidas na literatura (Paxton, 1999, Saxton e Benson, 2005). Trata-se de um conceito teórico cuja operacionalização não é consensual. Dado a característica multifacetada da relação entre a dinâmica ecológica e o controle da letalidade da ação policial, resolvi aplicar uma técnica de análise de componente principal nas possíveis dimensões empíricas relacionadas pela literatura ao construto teórico.

A base de dados é a pesquisa de vitimização realizado pelo IFB na cidade de São Paulo, no ano de 2003. A pesquisa teve amostra de cinco mil entrevistas selecionadas de forma probabilística e intencional, com base no setor censitário do IBGE. O objetivo principal foi garantir a comparabilidade individual entre os distritos. Além das perguntas sobre vitimização, foram realizadas questões sobre estilo de vida, grau de escolaridade, nível de renda, investimento pessoal em segurança e nível de participação comunitária e social. A pesquisa de campo foi realizada em quatro momentos diferentes. Cada bateria da pesquisa de campo teve uma amostra 
média de 1.250 entrevistas. Essa solução permitiu um rigoroso sistema de validação e consolidação dos resultados.

Os dados individuais foram agregados ao nível dos limites geográficos da 93 DP da capital do Estado. Investigou-se a taxa média de participação em: 1) associação de moradores (ass_mor); 2) sindicato ou associação profissional (sind); 3) instituição de caridade (inst_car); 4) clube social ou esportivo (club); 5) organização nãogovernamental (ong); 6) festa de rua; 7) atividade ligada a igreja, sem contar missa ou culto (igrej); 8) atividade comunitária (ativ_com); 9) reunião em associações (ass_com); 10) campanha de solidariedade (camp_sol); 11) mutirão para construção de casas ou limpeza de ruas, valões, etc (mut); 12) atendimento à vítimas de desabamentos, enchentes, incêndio, etc (atend_com); 13) algum outro tipo de atividade comunitária ou social (out_com) e 14) qualquer outro tipo de associação (inst_out). O nível de proximidade entre vizinhos foi medida por meio de perguntas: 15) se a pessoa recorreu recentemente a algum vizinho para pedir seu auxílio (ajud_rec); 16) se algum vizinho solicitou ajuda (ajud_solic); 17) se as pessoas são propensas a ajudar as outras pessoas (ajud_esp). Para mensurar a confiança difusa nas pessoas de maneira geral foi perguntado: 18) se as pessoas querem ajudar ao outro ou se as pessoas só estão preocupadas com elas mesmas? (conf1); 19) pode-se confiar nas pessoas ou deve-se ficar de "pé-atrás" ao lidar com elas? (conf2); 20) se a maioria das pessoas pensa em tirar vantagem do(a) $\operatorname{sr}($ a) se tiver uma chance, ou se a maioria das pessoas tenta ser correta? (conf3); 21) qual a avaliação pessoal sobre a confiabilidade das pessoas (conf4) e 22) qual a disposição pessoal em confiar nas pessoas (conf5). Sobre o grau de confiança nas pessoas do círculo próximo, amigos, parentes ou vizinhos, foi questionado se o entrevistado: 23) emprestaria um xícara de açúcar a um vizinho (conf7); 24) emprestaria $\mathrm{R} \$ 20,00$ a um vizinho (conf8); 25) emprestaria seu ferro de passar roupas, furadeira ou outro utensílio doméstico para um vizinho (conf9); 26) deixaria a chave da sua casa com um vizinho (conf10); 27) emprestaria seu televisor se fosse viajar (conf11); 28) se você tiver filhos, pediria para um vizinho tomar conta para você? (conf12). Por fim, outra dimensão teoricamente 
apontada pelo nível de atividade social, um dos fatores intervenientes do desenvolvimento comunitário foi medida pela presença média da população do distrito em: 29) cinema (cin); 30) show ou concerto de música (show); 31) praia ou parque (praia); 32) bar ou casa noturna (boate); 33) shopping (shopp); 34) jogo de mesa como cartas, dama, dominó ou outro (jog_mes); 35) atividade esportiva como futebol, basquete, tênis, boliche, etc (ativ_esp); 36) atividade física como aula de dança, ginástica ou outra (ativ_fis); 37) museu ou uma exposição de arte (art); 38) pesca ou acampamento (ativ_camp); 39) evento esportivo amador ou profissional ao vivo (event_esp); 40) bingo (bing) e 41) clube social ou esportivo (clube).

Nos dados agregados, foi aplicado modelo de análise de componentes principais para reduzir as 41 dimensões do desenvolvimento comunitário para um conjunto de variável menor. Utilizando o critério de Kaiser, que propõe a manutenção dos autovalores acima de 1 , reduziu-se os dados para 3 fatores ou variáveis latentes. Foi empregada rotação dos eixos que representam as novas variáveis criadas pelo modelo do tipo Varimax que impede qualquer correlação entre os fatores e aumenta o poder interpretativo dos mesmos. Esse tipo de rotação evita, ainda, a colinearidade das novas variáveis.

O primeiro fator responde por $54,34 \%$ da variabilidade da amostra e está associado ao nível de confiança difusa e predisposição ao contato próximo com vizinho e amigo (conf). O gráfico 14 apresenta as variáveis mais correlacionadas com a primeira dimensão encontrada na ACP. O círculo vermelho simboliza graficamente a nova variável criada. O segundo fator, apresentado no gráfico 15 responde por 22, $41 \%$ da variabilidade total da amostra e está associado às formas institucionalizadas de participação comunitária, tais como participação em sindicatos, instituições comunitárias em geral e organizações não-governamentais e, ainda, à intensa vida social do distrito (ativ_soc). Por fim, o terceiro fator está relacionado às atividades realizadas para o desenvolvimento comunitário (ativ_com), tais como participação em associação de moradores, mutirões e outras associações comunitárias. A nova 
variável, ativ_com, responsável por menos de 1\% da variabilidade total da amostra, é apresentada no gráfico 16.

A combinação dos três fatores responde por mais de $80 \%$ da variabilidade total da amostra e ajuda a desvendar a caixa-preta conceitual do corpo teórico voltado para investigar o impacto da dinâmica ecológica no desempenho institucional da polícia. Das dimensões normalmente apontadas na literatura, a confiança, a atividade sociopolítica e a atividade comunitária são dominantes em relação às outras dimensões pesquisadas. Os valores individuais dos três fatores - conf, ativ_soc, ativ_com - foram redistribuídos nos anos de 2001 e de 2002. A idéia subjacente a utilização dos resultados do APC nos outros dois anos que compõem a amostra é o suposto teórico de que as estruturas ecológicas dos distritos da cidade são estáveis no tempo. A presença de alto índice de confiança, de atividade social e de atividade comunitária não sofre grande alteração de um ano para o outro.

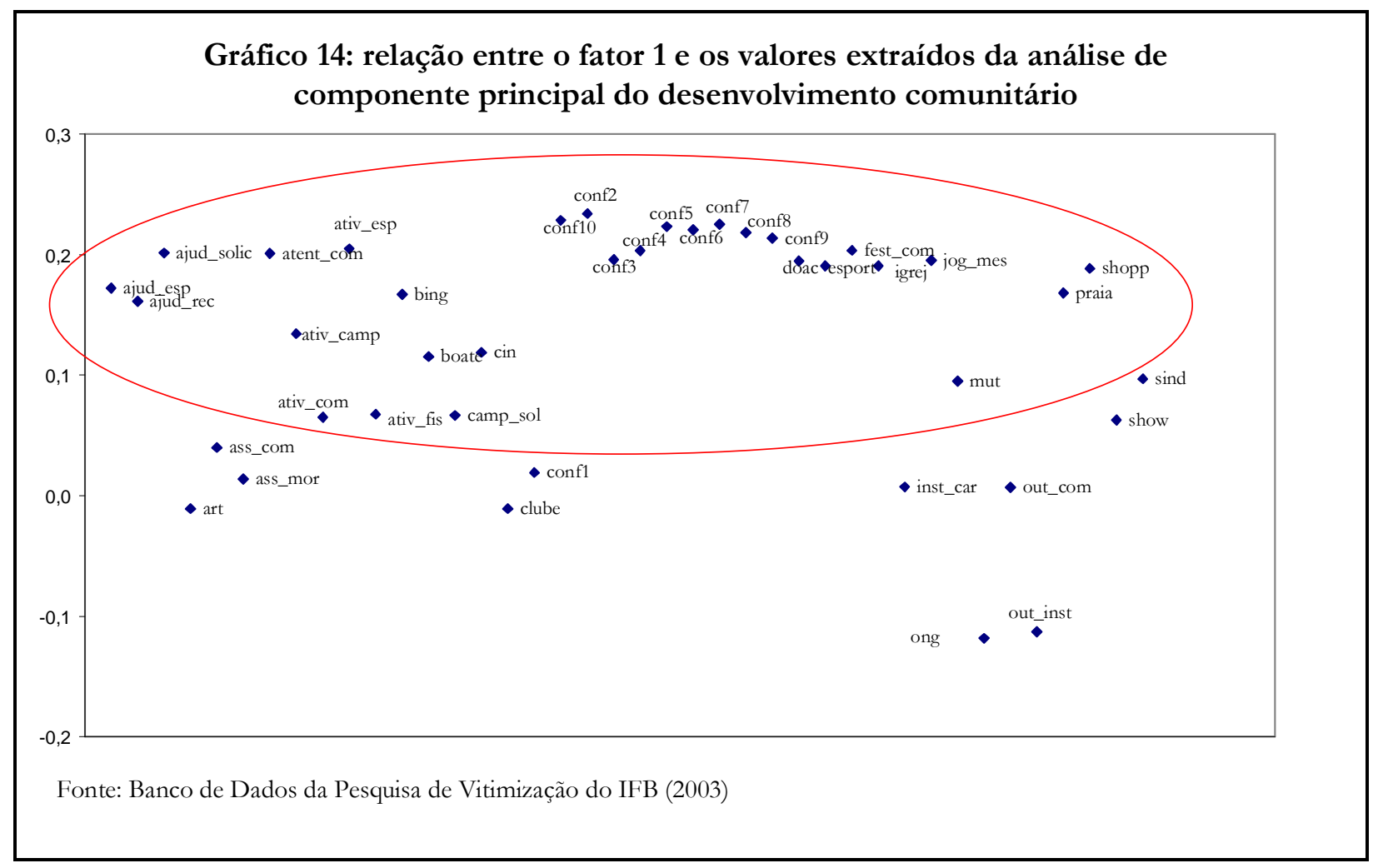



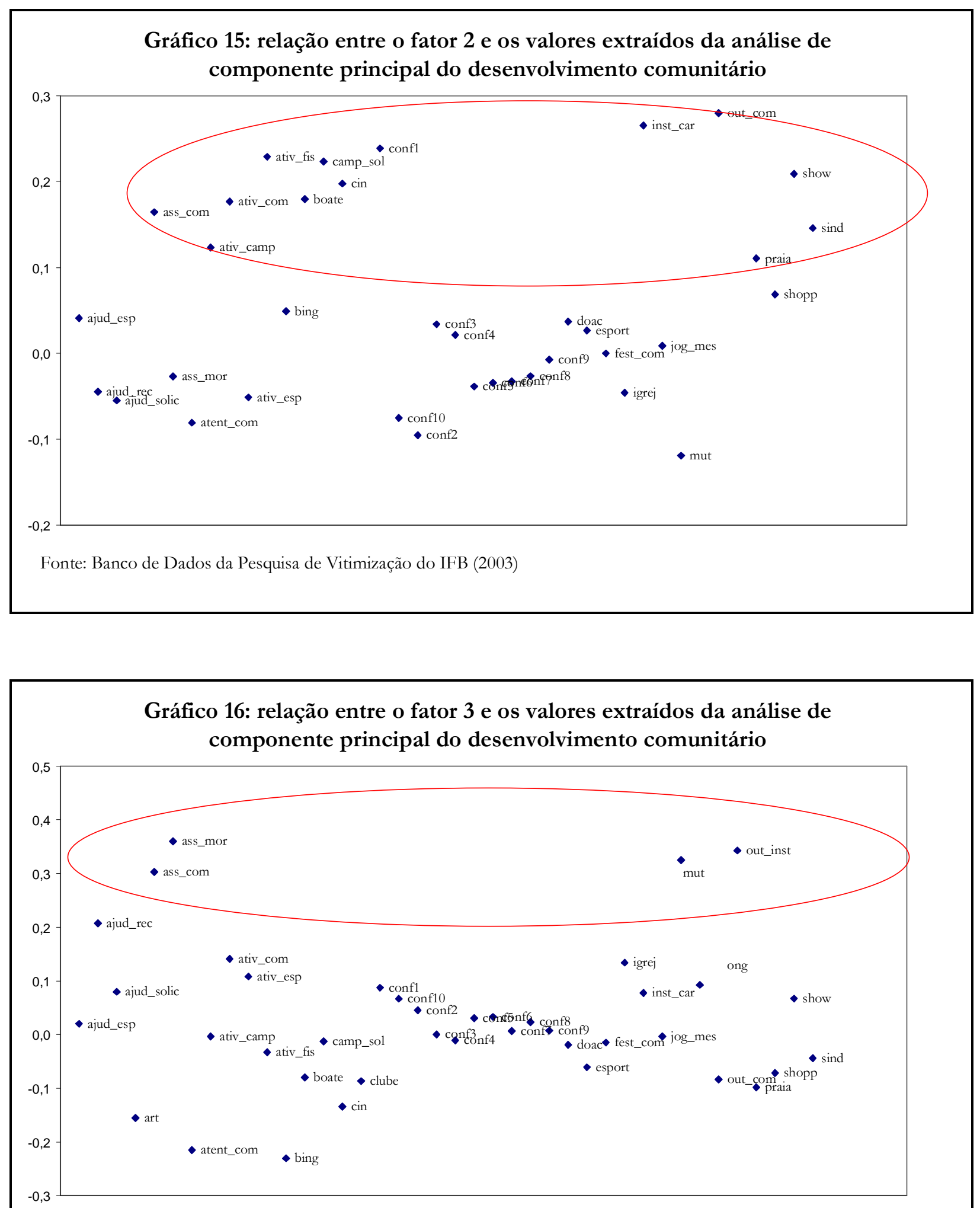

Fonte: Banco de Dados da Pesquisa de Vitimização do IFB (2003) 


\section{Estatísticas descritivas}

As estatísticas descritivas das variáveis independentes serão apresentadas sucintamente nessa secção. Como pode ser verificado do na tabela 3, o crime de patrimônio apresenta desvio padrão de 1,52, com valor máximo de 6,08 e mínimo de -2,10. A maior dispersão é dos crimes violentos, desvio padrão de 1,57, valor máximo 6,03 e mínimo de -2,61. Os crimes relacionados trafico de entorpecentes têm o valor máximo de 6,32, mínima de -3,61 e desvio padrão de 1,31.

Entre as variáveis ecológicas, a maior dispersão é da confiança, desvio-padrão de 5,2, valor máximo de -11,1 e mínimo de 13,9. A atividade comunitária é a variável ecológica mais homogeneamente distribuída na amostra, desvio padrão de 1,0, máxima de -1,74 e mínima de 3,66. A atividade política tem máxima de 8,31, mínima de -5,04 e desvio-padrão de 2,95.

$\mathrm{Na}$ distribuição das variáveis sociais, a variável desorganização social tem mínima de -4,30, máxima de 6,12 e desvio-padrão de 2,48. A desorganização física possui desvio-padrão de 1,47, máxima de 5,08 e mínima de -2,10. Por fim, o valor máximo da variável é de 3,48, o mínimo é de -4,78 e desvio-padrão é de 1,29.

Outra vantagem da ACP é a interpretação pública dos resultados empíricos. Com ela o poder público pode formular políticas com mais meticulosidade, pois não restringe a letalidade da ação policial a uma única ordem de fator, mais sim aos fatores latentes presentes na realidade social. 


\begin{tabular}{lccccc}
\hline \multicolumn{7}{l}{ Tabela 4: estatísticas descritivas } & & & \\
\hline Variável & Obs & Média & DP & Min & Max \\
crim_patr & 279 & 0,00 & 1,52 & $-2,10$ & 6,08 \\
crim_viol & 279 & 0,00 & 1,57 & $-2,61$ & 6,03 \\
crim_drog & 279 & 0,00 & 1,31 & $-3,61$ & 6,32 \\
ativ_com & 93 & 0,00 & 1,34 & $-1,74$ & 3,66 \\
ativ_pol & 93 & 0,00 & 2,95 & $-5,04$ & 8,31 \\
Conf & 93 & 0,00 & 4,66 & $-9,79$ & 12,84 \\
des_social & 93 & 0,00 & 2,48 & $-4,30$ & 6,12 \\
des_fisica & 93 & 0,00 & 1,47 & $-2,10$ & 5,08 \\
Renda & 93 & 0,00 & 1,26 & $-4,78$ & 3,48 \\
\hline
\end{tabular}

A ACP empregada para viabilizar o tratamento adequado das variáveis independentes tem a desvantagem de tornar complicada a interpretação dos valores das variáveis latentes extraídas no procedimento. Todas as variáveis criminais, ecológicas e sociais têm média zero e estão distribuídas entre valores negativos e positivos. As tabelas 13, 14 e 15, no anexo, apresentam as estatísticas descritivas de cada uma das variáveis utilizadas para construir as variáveis independentes. No entanto, as vantagens da opção pela ACP são tão intensas que justificam a opção. Dentre elas, uma merece ser destacada, a baixa correlação entre as variáveis latentes. Um dos principais problemas nas análises de regressão multivariada é a existência de variáveis independentes altamente correlacionadas que implica em multicolinearidade. Os valores estimados no modelo de regressão na presença de multicolinearidade apresentam grandes variâncias e covariâncias, tornado-os imprecisos e com maior probabilidade de serem rejeitados (Gujarati, 2000). A despeito do problema ser mais acentuado nos modelos estimados por método do mínimo múltiplos quadrados, a multicolinearidade também merece atenção nos modelos estimados por máxima verossimilhança. 
As opções alternativas para lidar como o problema, além da APC são: i) escolha de uma variável para colocar no modelo de regressão e ii) somatória das variáveis correlacionadas. A escolha de uma variável aumenta a compreensão dos resultados dos modelos de regressão, mas reduz o alcance da explicação substantiva, pois descarta, a priori, variáveis potencialmente importantes. A somatória das variáveis correlacionadas apresenta o mesmo problema de interpretação dos valores extraídos na APC e não deixa de desconsiderar fatores potencialmente importantes. Ou seja, a Análise de Componente Principal é o recurso mais adequado para lidar com o problema porque permite tratar com uma massa grande de informação social sem a perde de qualidade técnica. 


\section{Capítulo 4}

\section{Determinantes da letalidade policial em São Paulo}

Conforme discutido, a estratégia de análise do material empírico será empreendida em etapas. No primeiro momento, buscará estabelecer a relação de cada dimensão social com a letalidade. A tabela 5 apresenta os resultados do modelo de regressão bivariado para todas as variáveis independentes que compõe a primeira etapa de análise do material empírico. No segundo momento, foram criados modelos multivariados que permitem testar as interações entre as dimensões situacionais, contextuais, institucionais e ecológicas na determinação da letalidade da ação policial. A tabela 6 exibe tais modelos. Por fim, recorreu-se a uma série de teste sobre a consistência e a validade dos modelos de regressão multivariados. As tabelas 7 e 8 apresentam os resultados encontrados na etapa de verificação da validade dos modelos de regressão multivariados. Como foi utilizada a análise de componente principal (APC) para reduzir as variáveis àqueles fatores latentes, que dão significância ao mundo social, a interpretação dos resultados dos modelos de regressão será realizada, na grande maioria dos casos, por meio da variação em desvio-padrão dos fatores na probabilidade da presença de letalidade nos distritos da cidade de São Paulo.

A tabela 5 exibe o resultado do modelo de regressão bivariado. Diferentemente do que amplamente divulgado por pesquisas acadêmicas nacionais (Caldeira, 2000; Pinheiros 1991, entre outros), o crime de patrimônio não aumenta a probabilidade da letalidade da ação policial. A probabilidade de letalidade está significativamente associada com os crimes violentos, a variação de um desvio padrão no indicador representa um aumento de $34,40 \%$ de pessoas mortas pela polícia nos distritos. Também, está associado positivamente aos crimes de droga, um impacto de 15,70\% para cada variação do desvio padrão desses crimes. Ou seja, o controle da atividade 
criminal do distrito pode amenizar significativamente o número de mortes pela polícia. Isso não implica, evidentemente, que a letalidade resulta em menos crimes. Quando tenta-se estabelecer o impacto da letalidade na dinâmica criminal, o efeito foi inverso ao predito. A letalidade tem impacto positivo nos crimes violentos, ou seja, quando maior letalidade na ação policial mais crime violento. É como se, a ação violenta da polícia engendrasse uma onda de violência. $\mathrm{O}$ mesmo efeito está presente na letalidade. O comportamento da letalidade nos crimes de patrimônio e a relação de causalidade inversa merecem atenção.

Como já foi discutido, os crimes ao patrimônio são sensíveis ao padrão de atuação da polícia. As instituições policiais mais eficientes tendem a apresentar mais crimes de patrimônio do que a média da cidade. Aparentemente, esse tipo de crime funciona como um indicador dos departamentos de polícia que recorrem menos à letalidade e mais a estratégias investigativas de policiamento ou de maior eficiência de gerenciamento com o público usuário dos serviços policiais. Isso explicaria a ausência de relevância estatística dos crimes de patrimônio na letalidade, ou seja, não existe relação entre qualidade do serviço policial e a presença de letalidade. As estratégias bivariadas não permitem inferências consistentes, mas dão boas pistas sobre $\mathrm{o}$ comportamento de cada variável no fenômeno estudado. Esse assunto será retomado na análise dos modelos multivariados. O efeito da letalidade no crime de patrimônio também não apresenta significância estatística. Os resultados da análise do impacto da letalidade nas variáveis criminais foram omitidos deste trabalho porque não formam o foco principal.

As variáveis contextuais apresentam uma relação com a letalidade consistente com a predição teórica. A letalidade está concentrada nos distritos com intensidade de desorganização social. A variação positiva do aumento de desvio-padrão da medida implica em um incremento de $26,60 \%$ da letalidade e com maior grau com presença de desorganização social, variação de 30,90\% para cada aumento de um desviopadrão. A renda é a única das variáveis socioeconômicas com uma relação ambígua com letalidade. A variável apresenta significância estatística no modelo bivariado, 
embora reduzido. A variação é de 4,10\% da cada incremento de um desvio-padrão na renda. A questão a ser notada é a direção da relação, esperavasse que a renda apresentasse um efeito negativo na letalidade. Distrito com maiores rendas, em tese, só apresentariam maior letalidade na presença de altas taxas de crimes de patrimônio ou de droga, caso contrário, o poder aquisitivo da clientela das instituições policiais serviriam como um inibidor às soluções violentas dos confrontos. Mais uma vez, os limites técnicos das análises bivariadas reduzem a validade das inferências. $\mathrm{O}$ assunto será tratado como maior rigor no momento oportuno.

As variáveis institucionais apresentam impactos significativos quando testadas individualmente. A mudança de secretário, conforme já foi demonstrado na Tabela 2, representa uma diferença de 15,30\% no padrão de letalidade da polícia de São Paulo. As seccionais de polícia são um importante fator explicativo da probabilidade de letalidade na ação policial de São Paulo. Tomando como referência a seccional de policia 1, localizada na região central da cidade, seis das outras sete seccionais, possuem padrão de letalidade significativamente distinto. Os destaques são a seccional 4 e a seccional 8 , com média de mortes pela polícia superior $50 \%$ da seccional 1 e a seccional 5, com média 58\% menor. Como predito teoricamente, não existe uma definição a priori sobre a direção sinal da relação entre as variáveis institucionais e a concentração da letalidade policial. As instituições policiais tanto podem controlar o comportamento do policial, reduzindo, assim, a taxa de letalidade da área como podem incentivar os confrontos que aumentam a probabilidade de letalidade da região.

A tabela 5 demonstra, ainda, que todas as variáveis ecológicas estão associadas individualmente com a concentração de letalidade da ação policial. A presença de altas taxas de mortes pela polícia nos distritos está diretamente relacionada com o tipo de interações sociais presentes na área. Quanto maior a presença de atividade comunitária maior a probabilidade de altas taxas de letalidade, uma variação positiva de um desvio padrão no indicador representa $21,10 \%$ mais casos de letalidade. A concentração de confiança, também, apresenta uma relação estreita com distribuição 
de letalidade na cidade. Mas, ao contrário do que se esperava, a relação não é negativa, e sim é positiva. A variação de um desvio-padrão no nível de confiança do distrito implica um incremento de 39,70\% na taxa de letalidade. O impacto da participação política da população do distrito é significativo e um pouco menos intenso do que os demais indicadores ecológicos. A variação é de 13,30 para cada desvio padrão da medida.

\begin{tabular}{|c|c|c|c|c|c|c|c|}
\hline & Intercepto & Std. Err. & Coef. & Std. Err. & $\% \operatorname{StdX}$ & LR $X^{2}$ & $\mathrm{R}^{2}$ \\
\hline crim_patr & 1,44 & 0,03 & 0,01 & 0,02 & 1,40 & 0,22 & 0,00 \\
\hline crim_vio & $1,39 *$ & 0,03 & $0,19 *$ & 0,02 & 34,40 & $130,21 *$ & 0,08 \\
\hline crim_drog & $1,42^{*}$ & 0,03 & $0,11^{*}$ & 0,02 & 15,70 & $27,87^{*}$ & 0,01 \\
\hline des_social & $1,15^{*}$ & 0,03 & 0,09 & 0,01 & 26,60 & $50,27 *$ & 0,04 \\
\hline des_fisica & $1,13^{*}$ & 0,03 & 0,18 & 0,02 & 30,90 & $81,57^{*}$ & 0,06 \\
\hline renda & $1,17^{*}$ & 0,03 & 0,03 & 0,02 & 4,10 & 1,27 & 0,00 \\
\hline $\operatorname{secr}(\mathrm{a})$ & $1,01^{*}$ & 0,06 & $-0,14^{*}$ & 0,07 & 15,30 & $3,96 *$ & 0,00 \\
\hline $\sec 2^{(a)}$ & 1,19 & 0,03 & $-0,16$ & 0,11 & $-15,20$ & 2,16 & 0,00 \\
\hline $\sec 3^{(a)}$ & $1,19 *$ & 0,03 & $-0,12^{*}$ & 0,09 & $-11,30$ & $1,67^{*}$ & 0,00 \\
\hline $\sec 4^{(a)}$ & $1,10^{*}$ & 0,03 & $0,45^{*}$ & 0,08 & 58,20 & $26,58^{*}$ & 0,01 \\
\hline $\sec 5^{(a)}$ & $1,25^{*}$ & 0,03 & $-0,82^{*}$ & 0,13 & $-56,40$ & $45,60 *$ & 0,03 \\
\hline $\sec 6^{(a)}$ & $1,13 *$ & 0,04 & $0,28^{*}$ & 0,08 & 32,00 & $9,55^{*}$ & 0,00 \\
\hline $\sec 7(a)$ & 1,16 & 0,03 & $0,07^{*}$ & 0,09 & 8,00 & $0,63^{*}$ & 0,00 \\
\hline $\sec 8^{(a)}$ & $1,12^{*}$ & 0,03 & $0,46^{*}$ & 0,09 & 59,20 & $21,81^{*}$ & 0,01 \\
\hline ativ_com & $1,15^{*}$ & 0,03 & $0,14^{*}$ & 0,02 & 21,1 & $36,71^{*}$ & 0,02 \\
\hline conf & $1,12^{*}$ & 0,35 & $0,07 *$ & 0,00 & 39,7 & 105,18 & $0,07^{*}$ \\
\hline ativ_pol & $1,17^{*}$ & 0,03 & $0,04^{*}$ & 0,01 & 12,6 & 13,30 & $0,00^{*}$ \\
\hline
\end{tabular}

Fonte: Banco de dados de Letalidade da SSP-SP, 2007

A Tabela 6 exibe os modelos de regressão multivariado, partindo do modelo mais simples de ação, onde as opções individuais são realizadas de acordo com a situação criminal em que os policiais enfrentam nas suas atividades diárias, até o 
modelo mais complexo, onde se assume que existe uma relação complexa entre situação, contexto e instituição.

O efeito líquido dos crimes violentos tem significância estatística quando considerados somente os fatores criminais. Cada variação positiva de um desvio padrão dos crimes violentos significa um incremento de $35,40 \%$ na probabilidade de presença de letalidade no distrito. Os crimes de droga apresentam padrão similar aos crimes violentos, com impacto de 12,60\% para cada desvio padrão. Os crimes contra patrimônio não apresentam impacto significativo na distribuição da letalidade na cidade de São Paulo. No entanto, o sinal da relação é negativo, o que reforça a tese de que a presença de crime contra patrimônio está associada a uma certa organização das instituições policiais e não a dinâmica criminal em si. $\mathrm{O}$ teste para qualidade geral do modelo é significativo ao nível de 95\% $\left(\right.$ LR X $\left.X^{2}=161,51 *\right)$.

Long (1997) demonstra que coeficiente de determinação $\left(\mathrm{R}^{2}\right)$ não possuí a mesma eficiência interpretativa nos modelos para variável dependente categórica que apresenta nos modelos de regressão linear. Além disso, Gujariti (2000) prova que nas análises em que se combinam dados de séries temporárias e dados de corte (crosssection) tendem apresentar coeficientes de determinação muito baixos. Mesmo quando os resultados empíricos são altamente favoráveis à comprovação das hipóteses teóricas. Por isso, a atenção $\mathrm{R}^{2}$ dos modelos será reduzida. A principal medida de qualidade de ajuste dos modelos de regressão de poisson é o coeficiente médio de máxima verossimilhança do modelo (LR $\mathrm{X}^{2}$ ). $\mathrm{O}$ asterisco acima de valor exibido na penúltima linha da tabela 8 indica que o modelo apresenta significância estatística ao nível de 95\%. A importância do LR $X^{2}$ para o teste de ajuste do modelo será reintroduzida quando for comparada a eficiência de cada modelo de regressão.

Quando se acrescenta contexto sócio-urbano ao modelo 1, as variáveis criminais ajustam seus impactos na letalidade da ação policial. Isso sugere que os fatores criminais e socioeconômicos interagem positivamente no desfecho letal de ação policial. Quando são consideradas, a desorganização social, a desorganização física e a renda do distrito, a variação positiva de um desvio-padrão dos crimes 
violentos implica em média, uma probabilidade $26,40 \%$ de casos de letalidade e os crimes de droga incrementam $16,40 \%$ a probabilidade. O efeito líquido das variáveis contextuais são 12,10\% para um desvio-padrão de desorganização social, 8,60\% para a desorganização física e 12,70\% para renda. O comportamento da variável renda está em acordo ao esperado no modelo teórico interacional. A associação entre renda e crime aumenta a probabilidade de mortes pela polícia. Novamente, as evidências sobre a relação inversa entre crime de patrimônio e letalidade ficam patentes. O teste para qualidade geral do modelo é significativo ao nível de 95\% (LR X $\left.{ }^{2}=197,19 *\right)$.

A introdução das oito variáveis qualitativas, que busca captar o efeito de dinâmica institucional no comportamento letal do policial, agrega consideravelmente qualidade as explicações sobre os determinantes da letalidade policial em São Paulo. O teste de qualidade de modelo 2 é mais alto do que o modelo contextual e metade das variáveis institucionais apresentam significância estatística ao nível de 90\%. A mudança de um secretário de Segurança Pública de São Paulo com o perfil mais preocupado com o controle da letalidade da ação policial (secretário Petrelluzzi, categoria de referência do modelo 2) para um secretário cuja plataforma era mais para o confronto (secretário Ramos) significou um aumento médio de 29,20\% no número de letalidade na cidade de São Paulo. As seccionais de polícia, também, apresentam padrões dissimilares de letalidade, mesmo quando do controlado pelo nível de crime e contexto social dos distritos. Um distrito situado no centro da cidade tem em média metade do número de mortes pela polícia do que os distritos localizados em outras regiões da cidade, isso mesmo se os dois tiveram o mesmo nível de socioeconômico e o mesmo padrão criminal. Não foram encontradas evidências de interação entre os fatores institucionais e situacionais, nenhuma das variáveis criminais sofreu alteração superior a 10\%, limite estabelecido na literatura como indício de interações entre fatores sociais. No entanto, o efeito dos fatores socioeconômicos se ajusta significativamente com a introdução das variáveis institucionais. O modelo é significativo ao nível de 95\% $\left(\operatorname{LR~X}{ }^{2}=253,14 *\right)$. 
O último modelo apresentado na tabela 6 integra todas as explicações tradicionais sobre letalidade policial. A introdução de indicadores sobre o tipo de relações comunitárias que caracterizam o distrito agrega poder explicativo à análise empírica. O nível de atividade política do distrito apresenta sinal compatível com o modelo teórico, no entanto, não apresenta significância estatística ao nível de $90 \%$. A variação positiva de um desvio padrão de atividade política implica em uma redução de $2,30 \%$ na probabilidade de ação letal da polícia. A presença de confiança no distrito, indicador clássico das análises ecológicas, apresenta um efeito inesperado no nível de morte da polícia, um incremento de 13,80\% para cada um desvio padrão da medida. Ou seja, quanto maior nível de confiança da comunidade, maior a taxa de letalidade do distrito. Efeito semelhante foi encontrado na análise bivariada. E futuras pesquisas são necessárias para compreender essa relação. $O$ impacto da atividade comunitária também é um desafio à predição teórica. Quanto menor o nível de atividade comunitária, maior a concentração de letalidade da ação policial no distrito.

A despeito, das dificuldades de interpretação substantiva das variáveis ecológicas introduzidas no modelo interacional, o efeito de ajuste no modelo como todo e na maioria das variáveis independentes são altamente significativos teoricamente. A interação entre as variáveis ecológicas e as variáveis institucionais acontece exatamente como prevista pela teoria interacional. O perfil do secretário de Segurança Pública do Estado de São Paulo perde cerca de cinco ponto percentuais de importância na explicação sobre o número de pessoas mortas pela polícia, passando de um efeito líquido de $29,2 \%$ para um de $28,0 \%$. Nas outras variáveis, a interação com a ecologia urbana é ainda mais significativa. A variação nos estimadores institucionais vai de $30 \%$ a mais de $1.000 \%$. Ou seja, como especificado, a ecologia urbana pode não apresentar um efeito direto na letalidade, mas certamente possuí um efeito indireto nas instituições policiais. A introdução da dimensão ecológica, também, apresenta um impacto na desordem física (-191,70\%), no crime de patrimônio $(-182,2 \%)$ e no crime de droga $(31,90 \%)$. 


\begin{tabular}{|c|c|c|c|c|c|c|c|c|c|c|c|c|}
\hline & \multicolumn{3}{|c|}{ Modelo 1} & \multicolumn{3}{|c|}{ Modelo 2} & \multicolumn{3}{|c|}{ Modelo 3} & \multicolumn{3}{|c|}{ Modelo 4} \\
\hline & Coef. & Std. Err. & $\% \operatorname{StdX}$ & Coef. & Std. Err. & $\% \operatorname{StdX}$ & Coef. & Std. Err. & $\% \operatorname{StdX}$ & Coef. & Std. Err. & $\% \operatorname{StdX}$ \\
\hline crim_patr & $-0,01$ & 0,02 & $-1,10$ & 0,02 & 0,02 & $-3,90$ & $-0,02$ & 0,02 & $-3,50$ & 0,01 & 0,03 & $-1,20$ \\
\hline crim_vio & $0,19 *$ & 0,02 & 35,40 & $0,15^{*}$ & 0,03 & 26,40 & $0,17^{*}$ & 0,03 & 29,90 & $0,15^{*}$ & 0,03 & 27,80 \\
\hline des_fisica & -- & -- & -- & $0,06^{*}$ & 0,03 & 8,60 & 0,02 & 0,03 & 8,20 & 0,05 & 0,03 & 2,90 \\
\hline renda & -- & -- & -- & $0,10^{*}$ & 0,02 & 12,70 & $0,12^{*}$ & 0,03 & 16,00 & $0,10^{*}$ & 0,03 & 13,00 \\
\hline secr & -- & -- & -- & -- & -- & -- & $0,26^{*}$ & 0,07 & 29,20 & $0,24^{*}$ & 0,07 & 28,00 \\
\hline $\sec 2$ & -- & -- & -- & -- & -- & -- & 0,09 & 0,16 & 9,20 & 0,01 & 0,18 & $-0,10$ \\
\hline $\sec 6$ & -- & -- & -- & -- & -- & -- & $0,36^{*}$ & 0,18 & 43,50 & 0,28 & 0,18 & 33,40 \\
\hline $\sec 7$ & -- & -- & -- & -- & -- & -- & $0,17^{*}$ & 0,16 & 18,60 & 0,11 & 0,16 & 11,70 \\
\hline $\sec 8$ & -- & -- & -- & -- & -- & -- & $0,37^{*}$ & 0,13 & 45,50 & $0,28^{*}$ & 0,16 & 33,50 \\
\hline ativ_com & -- & -- & -- & -- & -- & -- & -- & -- & -- & $-0,08^{*}$ & 0,03 & $-9,80$ \\
\hline conf & -- & -- & -- & -- & -- & -- & -- & -- & -- & $0,03^{*}$ & 0,01 & 13,80 \\
\hline ativ_pol & -- & -- & -- & -- & -- & -- & -- & -- & -- & 0,01 & 0,02 & 2,30 \\
\hline LR X ${ }^{2}$ & & $161,51 *$ & & & $197,19 *$ & & & $253,14^{*}$ & & & $263,34 *$ & \\
\hline $\begin{array}{l}\mathrm{R}^{2} \\
\mathrm{~N}=279\end{array}$ & & 0,10 & & & 0,12 & & & 0,15 & & & 0,16 & \\
\hline
\end{tabular}


As evidências discutidas são expressivas na comprovação da importância da análise empreendida, mas não são conclusivas. A presença de mais variáveis tende a incrementar artificialmente o poder explicativo dos modelos de regressão (Raftery, 1995). Outra questão que pode comprometer a validade da inferência dos modelos integrados é a falta de clareza sobre a verdadeira contribuição de um dos modelos teóricos (Heckman e Walker, 1987). Na maioria das vezes, a integração de duas teorias não resulta em modelos integrados coesos. Mas sim, em ajustes pontuais em um dos dois modelos teóricos (Hirschi, 1979).

A tabela 7 apresenta o teste de MV X² para modelos aninhados, onde se assume que os modelos são aninhados. Conforme pode ser verificado, as evidências são altamente favoráveis em relação ao modelo teórico proposto. A letalidade de polícia é determinada por uma série de fatores integrados. $\mathrm{O}$ teste indica que a probabilidade está associada aos fatores situacionais e esses por sua vez estão condicionados às características socioeconômicas do distrito. $\mathrm{O}$ valor de teste é 71,36 e os asteriscos encima de cada valor da tabela indicam que a confiabilidade da medida ao nível de 95\%, indicando que a não integração desses dois fatores representa um erro de especificação do modelo estatístico sobre a letalidade. Os dados mostram, ainda, que o efeito do modelo integrando situação-contexto (modelo 2 , na tabela 6 ) na letalidade policial é condicionado pelos fatores institucionais. O valor de teste é de 183,26 e com 95\% pode-se afirmar que existe aninhamento na relação de modelo 2 e do modelo 3 . Resultados similares são encontrados quando testa-se a relação entre o modelo 3 e o modelo 4. Como esperado o valor do teste caí para um nível crítico de significância (T MV X $\left.{ }^{2}=20,4\right)$. Duas conclusões são extraídas desses resultados. A primeira é que a não introdução das variáveis ecológicas na explicação sobre letalidade da ação policial torna o modelo incompleto. A segunda é que a introdução de outro conjunto de variáveis reduz a qualidade da análise estatística. Ou seja, o modelo interacional proposto é absolutamente eficiente para explicar a letalidade da ação policial em São Paulo. 


\begin{tabular}{lcccc}
\hline \multicolumn{4}{l}{ Tabela 7: teste para modelo aninhado } \\
\hline Modelo & LR X & situacional & contextual & institucional \\
\hline Modelo 1 & $161,51^{*}$ & & & \\
Modelo 2 & $197,19^{*}$ & $71,36^{*}$ & & \\
Modelo 3 & $253,14^{*}$ & $183,26^{*}$ & $111,9^{*}$ & \\
Modelo 4 & $263,34^{*}$ & $203,66^{*}$ & $132,3^{*}$ & $20,4^{*}$ \\
\hline
\end{tabular}

Para incrementar a confiabilidade das conclusões extraídas na análise estatística foi testado, ainda, se algum modelo paradigmático sobre comportamento policial apresenta forte prevalência sobre os demais. O que indicaria que o processo de integração teórico realizada não passa de ajuste pontuais em um dos modelos teóricos. As regressões de poisson realizadas para testar empiricamente tais modelos são apresentadas na tabela 16, no anexo. Não será realizada uma análise aprofundada do resultado, pois não é relevante para o desenvolvimento do argumento principal desse trabalho.

A tabela 8 apresenta testes que comparam modelos não-aninhados sobre letalidade. Quanto menor o valor de BIC, maior a evidência em favor dos modelos aninhados em relação ao modelo mais completo, dado que o BIC penaliza os modelos com maior número de variável. Evidentemente, os demais modelos teóricos são aninhados ao modelo interacional apresentado na última linha da tabela. A apresentação do modelo ajuda a dirimir qualquer dúvida sobre sua eficácia. Já o teste de discriminação com base no BIC, apresentado na tabela 8 , indica que o modelo interacional é mais eficiente do que os demais modelos. Nenhum dos modelos paradigmáticos é claramente superior aos demais. Os testes apontam por uma leve prevalência do modelo situacional, cuja diferença com o modelo interacional é a menor encontrada. Entre o modelo institucional e o modelo contextual não existe grande prevalência de um sobre o outro. Quando comparado o modelo institucional com o modelo ecológico, existem fortes evidências a favor do segundo. Esses resultados são altamente favoráveis a comprovação empírica do modelo interacional. Como predito pelo mapa teórico 
exibido com auxílio da figura 1, devemos entender a ação policial como sendo condicionada por vários níveis distintos. Ou seja, o que a literatura assume como hipóteses concorrentes são, na verdade, dimensões distintas de um mesmo modelo teórico.

\begin{tabular}{lcccccc}
\hline \multicolumn{7}{l}{ Tabela 8: teste para modelo não-aninhado } \\
\hline Modelos & BIC & situacional & contextual & institucional & ecológico & GL \\
Situacional & $-144,62$ & -- & -- & -- & -- & 3 \\
Contextual & $-109,06$ & 35,56 & -- & -- & -- & 3 \\
Institucional & $-97,62$ & 47,00 & $-11,44$ & -- & -- & 8 \\
Ecológico & $-120,37$ & 24,25 & 11,31 & 22,75 & -- & 3 \\
Interacional & $-167,63$ & 23,01 & 58,57 & 70,01 & 47,26 & 17 \\
\hline
\end{tabular}

As evidências empíricas reunidas no trabalho dão suporte a validade do modelo teórico interacional sobre os determinantes da letalidade policial em São Paulo. As interações entre os fatores criminais, sociais, institucionais e ecológicos aumentam decisivamente a probabilidade de um desfecho letal no encontro entre um policial e um não-policial em uma situação de risco. O desafio que se segue, dada a verificação do modelo teórico, é identificar sua aplicabilidade política e desvendar sua relevância social.

\section{O impacto da letalidade na opinião pública}

No processo de formulação e implementação de política pública, conhecer a opinião popular sobre a segurança pública agrega valor a ações policiais. Já que se relaciona com a confiança na polícia, incidindo diretamente na qualidade do trabalho policial. Pois entre outros efeitos, uma polícia melhor avaliada aumenta o incentivo a comunicação de atos delituosos e facilita o trabalho de investigação, entre outros efeitos positivos no policiamento. De outro lado, uma percepção negativa sobre o sistema de segurança pública, pode 
alterar rotinas sociais, dificultando a ocupação de espaços públicos durante determinados horários e dias da semana, desfavorecer investimentos econômicos e modificar alguns hábitos de consumo, mesmo se o risco de violência percebido ser desassociado do risco real.

É tema corrente entre os estudiosos da área de segurança pública que a população tende a dar apoio às práticas extralegais da polícia paulista no controle da violência e do crime. A população espera resultados imediatos para a insegurança coletiva, mas ao não confiar e não participar diretamente na gerência de seus problemas coletivos, inaugura um ciclo vicioso de aumento da letalidade sem resultados práticos no combate da violência (Caldeira, 2000 e Cardia, 1997, entre outros). Embora fundamentada logicamente, este tipo de argumentação carece de comprovação empírica. A questão que emerge desse debate é se realmente a população dá apoio às práticas ilegais da polícia ou se a ausência de modelo teórico adequado integrada as técnicas mais robustas de análise de dados empíricos tem levada à conclusões precipitadas dos pesquisadores, políticos e operadores do sistema de segurança pública.

A tabela 9 apresenta o resultado do modelo de regressão linear multivariado para responder a questão sobre o real suporte da população a uma polícia mais incisiva no combate ao crime. A variável dependente do modelo é média da avaliação da população sobre a polícia no distrito em que reside, retirado da pesquisa de vitimização do IFB. As variáveis independentes são as mesmas do modelo interacional mais o número de letalidade policial no distrito. Para cada morte pela polícia, a boa avaliação da instituição no distrito decresce em três por cento. O impacto do padrão de letalidade no distrito na avaliação negativa da polícia é significante mesmo quando controlado por fatores criminais, sociais, ecológicos e institucionais. As evidências empíricas atestam a importância do controle da letalidade. Os dados, também, auxiliam na compreensão da relação entre o perfil ecológico do distrito e a instituições policiais. Os distritos com intensa atividade comunitária apresentam índice de 
avaliação positiva da polícia significativamente maior do que os distritos com menor nível de atividade comunitária. A presença de altos níveis de confiança, também, favorece uma avaliação positiva das instituições policiais. A presença de alto nível de desordem física, alta taxa de participação política e concentração de renda são alguns dos fatores associados à avaliação negativa da polícia. Único crime que apresenta impacto significativo na avaliação da polícia é o crime de patrimônio, a concentração de outros crimes no distrito não significa baixas taxas da polícia. As variáveis institucionais apresentam um efeito não homogêneo na avaliação da polícia, sendo que em algumas seccionais o efeito da instituição é positivo e outras, por sinal de maneira mais intensa, negativo. Mas, para além da importância de fatores sociais, ecológicos e institucionais, é significativa a importância que a letalidade apresenta na avaliação da polícia.

As ações de confronto prejudicam a avaliação da polícia em São Paulo. Já está vastamente demonstrada, a relevância da boa avaliação da população sobre polícia para fortalecimento de um sistema de segurança púbica eficiente (Reisig e Parks, 2000 e Scaglion, e Condon, 1980, entre outros). Polícias melhor avaliadas apresentam menores taxas de subnotificação, incrementado a seu conhecimento da real dinâmica criminal que devem enfrentar. A boa avaliação aumenta, também, o envolvimento direto da população nos assuntos de segurança pública, por meio de denúncia espontânea das ações violentas e criminais e indiretamente, por meio do autocontrole do comportamento possivelmente anti-social e do controle mais efetivo do grupo de relação primária. Ou seja, a insistência em um padrão letal da ação policial é improdutiva do ponto de vista de políticas públicas de segurança coletiva e é nocivo para a relação entre a instituição e a população. 
Tabela 9: valores estimados para os coeficientes de regressão multivariada sobre o efeito de letalidade na avaliação da polícia

\begin{tabular}{|c|c|}
\hline Intercepto & $\begin{array}{l}0,544 * \\
(0,240)\end{array}$ \\
\hline Npol & $\begin{array}{c}-0,003^{*} \\
(0,002)\end{array}$ \\
\hline crimpatr & $\begin{array}{l}0,011^{*} \\
(0,002)\end{array}$ \\
\hline crimvio & $\begin{array}{l}-0,002 \\
(0,003)\end{array}$ \\
\hline crimdrog & $\begin{array}{c}0,001 \\
(0,003)\end{array}$ \\
\hline des_fisica & $\begin{array}{l}-0,003 \\
(0,004)\end{array}$ \\
\hline des_social & $\begin{array}{l}-0,015^{*} \\
(0,002)\end{array}$ \\
\hline rend_social & $\begin{array}{c}-0,010^{*} \\
(0,003)\end{array}$ \\
\hline Secr & $\begin{array}{l}-0,001 \\
(0,007)\end{array}$ \\
\hline $\sec 2$ & $\begin{array}{c}-0,038^{*} \\
(0,017)\end{array}$ \\
\hline $\sec 3$ & $\begin{array}{l}-0,071^{*} \\
(0,016)\end{array}$ \\
\hline $\sec 4$ & $\begin{array}{l}-0,005 \\
(0,017)\end{array}$ \\
\hline $\sec 5$ & $\begin{array}{l}-0,018 \\
(0,016)\end{array}$ \\
\hline $\sec 6$ & $\begin{array}{l}-0,06)^{*} \\
(0,018)\end{array}$ \\
\hline $\sec 7$ & $\begin{array}{l}0,030^{*} \\
(0,016)\end{array}$ \\
\hline $\sec 8$ & $\begin{array}{l}-0,015 \\
(0,018)\end{array}$ \\
\hline ativ_com & $\begin{array}{l}0,010^{*} \\
(0,014)\end{array}$ \\
\hline Conf & $\begin{array}{l}0,006^{*} \\
(0,002)\end{array}$ \\
\hline ativ_pol & $\begin{array}{l}-0,015^{*} \\
(0,002)\end{array}$ \\
\hline $\mathrm{R}^{2}$ & 0,37 \\
\hline $\mathrm{N}$ & 279 \\
\hline
\end{tabular}




\section{Capítulo 5}

\section{Considerações finais}

As teorias sociais devem estar a serviço do aumento do entendimento do comportamento humano, no tocante à compreensão da letalidade da ação policial ressalta-se que está em questão tanto um desafio acadêmico quanto ético. A vida de policiais e não-policiais não pode continuar a mercê de percepções individuais sobre os riscos reais ou potenciais dos encontros entre esses atores. É preciso construir mecanismo eficientes de controle da letalidade policial sem comprometer o sistema de segurança pública nem relaxar nos parâmetros civilizados de conduta dos agentes estatais. As forças policiais têm como prioridade principal à preservação da vida dos cidadãos. Nesse sentido, mais importante do que o desenho de boas conjunturas analíticas é a construção de modelos teóricos que resultem em políticas públicas eficazes.

Foi demonstrado que a persistência na utilização exacerbada no uso da força letal não apresenta suporte da população e nem apresenta impacto significativo na redução do crime e da violência. No entanto, não podemos assumir uma postura normativa e achar que toda e qualquer letalidade da ação policial é moralmente equivocada. Nenhum policial entra no serviço como o objetivo explícito de tirar a vida de alguém. O policial toma decisões individuais em um ambiente altamente complexo e com várias dimensões envolvidas. Ignorar esta peculiaridade da ação policial impossibilita qualquer análise consistente sobre a letalidade.

Isso não implica, evidentemente, em considerar os índices de letalidade da ação policial condizentes com uma sociedade cujo valor principal é a vida de seus cidadãos. A tolerância das instituições policiais com os homicídios cometidos por policiais dentro de preceitos legais e legítimos de combate ao crime e à violência 
cria o ambiente necessário para a proliferação das soluções extralegais para o problema de segurança pública. A comunidade desempenha um papel central nessa equação. A interação do perfil institucional e da estrutura ecológica da comunidade em que a instituição policial está inserida apresenta alto impacto nas taxas de letalidade. A indução do estreitamento dos laços entre instituições policiais deve ser encarada não só como um avanço no policiamento, mas também como uma medida profilática de combate à letalidade da ação policial. 


\section{Referências bibliográficas}

ADORNO, S. (1993). A Criminalidade Urbana Violenta no Brasil: um Recorte Temático. BID, Rio de Janeiro, n. 35. $1^{\circ}$ semestre, pp.3-24.

AKERS, KROHN, LANZA-KADUCE e RADOSEVICH (1979) Social Learning and Deviant Bebavior: A Specific Test of a General Theory. American Sociological Review, vol. 44, n.. 4

AKERS, R. (1990). Rational Choice, Deterrence, and Social Learning Theory in Criminology: in the Path not Taken. The Journal of Criminal Law and Criminology, Vol. 81 n. 3.

AKERS, R. (1998). Is Differential Association/Social Learning Cultural Desviance Theory? In: HENRY, S. e EINSTADTER, W. The Criminology Theory Reader. New York: New York Press.

ALPERT, G. e DUNHAM, R. (1992). Police Socialization and Police Subculture in Policing Urban America. Prospect Heights, IL, Waveland Press.

BAYLEY, D. (1985) Patterning of policing. A comparative international analysis.

News Brunswick, Rutgers University Press.

BIOESTATÍSTICA (2007). Análise de Variância. Acessado no Internet no site http://www2.mat.ua.pt/pessoais/AHall/Bioestat $\%$ C3\%ADstica/ANOVA. pdf, em Janeiro de 2007.

BITTNER, E. . (2003), Aspectos do Trabalho Policial. São Paulo, EDUSP.

BORDUA, D. e REISS, A. (1966). Command, Control, and Charisma; Reflections on Police Bureaucracy. The American Journal of Sociology. vol 72, $\mathrm{n}^{\circ} 1$.

BRAITHWAITE, J. (1989) Criminological theory and organizational crime. Justice

Quarterly vol. 6, n 3 
BRANTINGHAN, P. e BRANTINGHAN, P. (1981). Environmental Criminology. Beverly Hills, California. Sage.

BRITT, D. e TITTLE, C. (1975). Crime Rates and Police Behavior: A Test of Two bypotheses. Social Force. vol 54, $\mathrm{n}^{\mathrm{o}} 2$.

BURSIK (1982). Community Change and Patterns of Delinquency. American Journal of Sociology. vol. 88 , issue 4.

BURSIK (1998) Social Disorganization and Theory do Crime and Delinquency: Problems and Prospects. In: HENRY, S. e EINSTADTER, W. The Criminology Theory Reader. New York: New York Press.

CALDEIRA, T. (2000) Cidade de muros: crime, segregação e cidadania em São Paulo. São Paulo: Editora 34/Edusp.

CANO, I. (1997). The use of lethal force by police in Rio de Janeiro. Rio de Janeiro: ISER.

CARDIA, N. (1997) O medo da policia e as graves violaçôes dos direitos humanos. Tempo Social, no 9(1) p. 249-265, maio de 1997, São Paulo Tempo Social, São Paulo, USP.

CARNEIRO e OLIVEIRA (2002): Estratégias de Controle da Violência Policial: Notas de Pesquisa. In: ZAVERUCHA J. e BARROS M. Políticas de Segurança Pública: Dimensão da Formação e Impactos Sociais. Recife: Massangana.

CARNEIRO, L. (1999). Os determinantes do crime nas regiões metropolitanas do Rio de Janeiro e São Paulo. Relatório de Pesquisa, Banco Mundial.

CARNEIRO, L. (1999) Para medir a violência . In PANDOLFI, D., CARVALHO.

J. M., CARNEIRO. L. P. E GRYNSZPAN, M. Cidadania, Justiça e Violência. Rio de Janeiro, Fundação Getúlio Vargas.

COHEN, L. e FELSON (1980). Property Criminal Rate in the United States: A Macro-analysis 1947-1977. The American Journal of Sociology. Vol 86.

COHEN, L. e MACHALEK, R. (1988). A General Theory of Expropriative Crime: An Evolutionary Ecological Approach. The American Journal of Sociology. Vol 94, n. 3. 
COLEMAN, J. (1988), Social Capital in the creation of buman capital. American Journal of Sociology. Vol 94

CORNISH, D. e CLARKE, R. (1998). Understanding Crime Displacement: An Application of Rational Choice Theory. In: HENRY, S. e EINSTADTER, W. The Criminology Theory Reader. New York: New York Press.

CRANK, J., LANGWORTHY, R. (1992), "An institutional perspective of policing", Journal of Criminal Law and Criminology, Vol. 83

DATASUS (2007) acessado no site: http://w3.datasus.gov.br/datasus/datasus.php, em março de 2007.

EELLS (1996). Probabilistic Causal Interaction. Philosophy of Science, Vol. 53,n. 1

ELSTER, J. (1983) Explaining technical change: Cambridge University Press.

FRIEDRICH (1980). Police Use of Force: Individuals, Situations, and Organizations. Annals of the American Academy of Political and Social Science. Vol 452.

GLAESER E., SACERDOTE B., SCHEINKMAN J. A. (1996) Crime and Social Interactions - The Quarterly Journal of Economics, Vol. 111.

GRAnATO, J. e SCIOLI, F. (2004). Puzzles, Proverbs, and Omega Matrices: The Scientific and Social Significance of Empirical Implications of Theoretical Models (EITM). Perspectives on Politics. VOL 2

GORSKI, P. (2004). The Poverty of Deductivism: A Constructive Realist Model of Sociological Explanation. Sociological Methodology, Vol 34.

GOTTFREDSON e HIRSCHI (1990). A General Theory of Crime. Stanford University Press, Stanford

GUJARATI, D. (2000). Econometria básica. São Paulo, Makron Books.

HECKMAN e WALKER (1987). Using Goodness of Fit and Other Criteria to Choose among Competing Duration Models: A Case Study of Hutterite Data. Sociological Methodology, Vol. 17.

HENRY, S. e EINSTADTER, W. (1998). The Criminology Theory Reader. New York: New York Press. 
HENRY, S. e LANIER, M. (1998). The prism of crime: Arguments for an integrated definition of crime. Justice Quarterly, v. 15, n. 4

HIPP, J. e BOLLEN, K (2003). Model Fit in Structural Equation Models with Censored, Ordinal, and Dichotomous Variables. Sociological Methodology, Vol. 33.

HIRSCHI, T (1979). Separate and Unequal Is Better. Journal of Research in Crime and Delinquency. Vol 16

HUMAN RIGHTS WATCH (1997). Brutalidade Policial Urbana no Brasil, Mimeo.

JACOBS, D. e O'BRIEN, R. (1998). The Determinants of Deadly Force: A structural Analysis of Police Violence. American Journal of Sociology. vol. 103, issue 4.

KATZ, R. 1999. Building the Foundation for a Side-by-Side Explanatory Model: A

General Theory of Crime, the Age-Graded Life-Course Theory, and Attachment Theory. Western Criminology Review vol.1, n. 2

KING, KEOHANE and VERBA (1994). Designing Social Inquiry. Princeton, Princeton University. Press.

KMETA, J (1978). Elementos de econometria. São Paulo: Atlas.

LEMGRUBER, J. (1986). Polícia, Direitos Humanos e Cidadania: Notas para um Estudo. JESUS, D. (org.). Seminário Crime e Castigo. Rio de Janeiro. Ciência Hoje, vol. 2.

LEVIT'T, S. (1997). Using Electoral Cycles in Police Hiring to Estimate the Effect of Police on Crime. The American Economic Review. 1997, 87(3).

LISKA (1997). Modeling the Relationships Between Macro Forms of Social Control. Allen E. Liska. Annual Review of Sociology, Vol. 23.

MANNING (2005). The Study of Policing. Police Quarterly, Vol. 8, No. 1, 23-43

MASTROFSKI, S. (2004). Street-level Police Discretion. The Annals of American Academy of Political and Social Science.

MERTON, R. K. (1957). Social Theory and Social Structure, Glencoe, IL. The Free Press 
MESQUITA, P (1999). Violência policial no Brasil: abordagem teórica e práticas de controle. In: PANDOLFI, D., CARVALHO. J. M., CARNEIRO. L. P. e GRYNSZPAN, M. Cidadania, Justiça e Violência. Rio de Janeiro: Fundação Getúlio Vargas.

MESQUITA, P. (2007). Falta transparência na segurança pública. Acessado no site http://www.nevusp.org/conteudo/index.php?conteudo id=435 em março de 2007.

MESSNER, KROHN E LISKA (1989). Theoretical Integration in the Study of Crime and Deviance. Albany, NY: SUNY Press.

MESSNER, S. BAUMER, E. e ROSENFELD, R. (2004) Dimensions of Social Capital e and of Criminal Homicide. The American Sociological Review. Vol 69, ก. 6

MINGUARDI, G. (1992). Tiras, gansos e trutas. Cotidiano e reforma na policia civil. São Paulo: Página Aberta.

MOONEY-MARINI e SINGER (1988). . Causality in the Social Sciences. Sociological Methodology. Vol. 18

MORENOFF, J., SAMPSON, R., RAUDENBUSH S. (2001). Neighborbood structure, social processes, and the spatial dynamics of urban violence. Criminology, $\mathrm{n}$. 39

MUNIZ, J., MUSUMECI, L., LARVIE, P. e FREIRE, B. (1997). Resistências e dificuldades de um programa de policiamento comunitário. Tempo Social, $\mathrm{n}^{\circ}$ 9(1), $\mathrm{p}$. 197-213, São Paulo.

PEARSON e WEINER (1985) Toward an Integration of Criminological Theories. The Journal of Criminal Law and Criminology (1973-), Vol. 76, No. 1

PETTEE, MILNER e WELCH (1994). Levels of Social Intergration in Group Context and the Effects of Informal Sanction Threat on Desviance. Criminology, vol. 32, No. 1 
PINHEIRO, P. S. (1991b). Autoritarismo e Transição. São Paulo. Revista da USP. USP, n. 9.

PINHEIRO, P. S. et alii (1991a). Violência fatal: conflitos policiais em SP (81-89). São Paulo. Revista da USP. USP, n. 9.

PUTNAN, R. (2000). "Bowling Alone: the collapse and revival of American community". Simon \& Schuster. New York.

REISIG, M. e PARKS, R. (2000) Experience, Quality of Life, and Neighborbood Context: A Hierarchical Analysis of Satisfaction with Police. Justice Quarterly vol. 17 n. 3, September.

REISS, A. (1992). Police Organization in Twentieth Century. Crime and Justice. Vol 15.

ROUNTREE, LAND e MIETHE (1994). Macro-Micro Integration In The Study Of Victimization: A Hierarchical Logistic Model Analysis Across Seattle Neighborhoods. Criminology. Vol 15, n. 3

SAMPSON e GROVERS (1989). Community Structure and Crime: Testing SocialDisorganization Theory. The American Journal of Sociology. Vol 94, n. 4.

SAMPSON, RAUDENBUSH e EARLS (1997). Neighborhoods and Violent Crime: A Multilevel Study of Collective Efficacy. Science. Vol 777.

SCAGLION, R. e CONDON, R. (1980) Determinants of Attitudes toward City Police. Criminology Vol. 17 n. 4, February.

SEADE (2007) acessado no site: http://www.seade.gov.br. Em março de 2007. SHAW e McKAY (1942). Juvenile Delenquency and Urban Areas. Chicago: The University of Chicago Press.

SHERMAN, L. (1995). The Police. In: WILSON, James e PETERSILIA, Joan. Crime. Califórnia: ICS Press.

SMITH, FRAZEE e DAVISON (2000). Furthering The Integration Of Routine Activity And Social Disorganization Theories: Small Units Of Analysis And The Study Of Street Robbery As A Diffusion Process. Criminology. Vol. 38, n. 2. 
SOBER, E. (2002). Instrumentalism, Parsimony, and the Akaike Framework. Philosophy of Science, 69.

STARK R. (1998). Deviant Place: a theory of the ecology of crime. In: HENRY, S. e EINSTADTER, W. The Criminology Theory Reader. New York: New York Press.

SUPPES (1970) A probabilistic theory of causality. Acta Philosophica Fennica, 24 Amsterdam, North-Holland Pub. Co

SUTHERLAND, E. (1945). Is White-Collar Crime crime? American sociological review. Vol: 10

TERRILL \& REISIG (2003) Neighborbood context and police use of force. Journal of Research in Crime and Delinquency. Vol. 40, n. 3 August.

THOMBERRY, T. P. (1989). Reflections on the advantages and disadvantages of theoretical integration. In S. Messner, M. D. Krohn, \& A. E. Liska (Eds.), Theoretical integration in the study of crime and delinquency. Albany: State University of New York Press.

THORNBERRY, W. (1987). Toward an interactional theory of delinquency. Criminology, n. 25.

TORRES, H., MARQUES, E., FERREIRA, M. e BITTER, S. (2003) Pobreza e Espaço: padrões de segregação em São Paulo Revista do Instituto de Estudos Avançados, IEA - USP. vol. 17, n. 47

WHITE, M. (2003). Examining the Impact of External Influences on Police Use of Deadly Force over Time. Evaluation Review. Vol. 27. n. 1 February.

WIKSTROM P. e SAMPSON, R.. (2006) The Explanation of Crime: Context, Mechanisms and Development, Cambridge University Press.

WILSON, J. (1968). Varieties of Police Behavior: The Management of Law and Order in Eight Communities. Cambridge: Harvard Press.

ZALUAR, A. (2001). Violência e crime. In: MICELI, Sérgio (org.). O que ler na ciência social brasileira (1970-1995). São Paulo: Sumaré. 


\section{Anexos}

Tabela 10: Valores extraídos da ACP das variáveis criminais

\begin{tabular}{lccc}
\hline \multirow{1}{*}{ Variable } & Comp1 & Comp2 & Comp3 \\
\cline { 2 - 4 } furt & crim_patr & crim_vei & crim_viol \\
\cline { 2 - 4 } arm_fog & $-0,115$ & 0,542 & 0,234 \\
furt_vei & 0,541 & 0,037 & 0,133 \\
hom_dol & $-0,128$ & 0,507 & $-0,285$ \\
Latr & 0,545 & $-0,168$ & 0,137 \\
roub & 0,423 & 0,076 & $-0,209$ \\
roub_vei & 0,121 & 0,595 & 0,072 \\
seq & 0,310 & 0,188 & $-0,344$ \\
traf_coc & 0,272 & 0,065 & $-0,256$ \\
traf_mac & 0,119 & 0,144 & 0,564 \\
Arm_fog & 0,062 & 0,017 & 0,526 \\
Hom_dol & 0,08 & 0,03 & 0,56 \\
\hline Variância explicada & $-0,06$ & $-0,04$ & 0,58 \\
\hline
\end{tabular}




\begin{tabular}{lccc}
\hline \multicolumn{3}{c}{ Tabela 11: Valores extraídos da ACP } & das variáveis sociais \\
\hline \multicolumn{1}{c}{ Variável } & Comp1 & Comp2 & Comp3 \\
\hline Fav & des_social & desor_urb & renda \\
\cline { 2 - 4 } fav_area & $-0,02$ & 0,63 & $-0,09$ \\
Rend & $-0,01$ & 0,66 & 0,08 \\
prop_jov_cid & $-0,26$ & $-0,21$ & 0,17 \\
cres_pop & 0,26 & 0,16 & 0,31 \\
prop_jov_dist & 0,28 & 0,18 & $-0,05$ \\
mae_adol & 0,35 & 0,12 & $-0,06$ \\
não_esc & 0,40 & $-0,05$ & 0,02 \\
dens_pop & 0,39 & $-0,07$ & 0,02 \\
Fecund & 0,13 & $-0,13$ & 0,67 \\
esc_incomp & 0,39 & $-0,10$ & 0,05 \\
Fluxo & 0,39 & $-0,10$ & $-0,02$ \\
Variância explicada & $-0,18$ & 0,15 & 0,63 \\
\hline
\end{tabular}

Tabela 12: Valores extraídos da ACP das variáveis ecológicas

\begin{tabular}{lccc}
\hline \multicolumn{1}{r}{ Variável } & Comp1 & Comp2 & Comp3 \\
\hline & Conf & Ativ_soc & Ativ-com \\
\hline ajud_esp & 0,172 & 0,041 & 0,020 \\
ajud_rec & 0,161 & $-0,045$ & 0,207 \\
ajud_solic & 0,201 & $-0,055$ & 0,080 \\
art & $-0,011$ & 0,329 & $-0,155$ \\
ass_com & 0,040 & 0,165 & 0,303 \\
ass_mor & 0,014 & $-0,027$ & 0,605 \\
atent_com & 0,201 & $-0,081$ & $-0,215$ \\
ativ_camp & 0,135 & 0,123 & $-0,004$ \\
ativ_com & 0,065 & 0,177 & 0,141 \\
ativ_esp & 0,205 & $-0,051$ & 0,108 \\
\hline \multicolumn{4}{c}{ Continua na próxima página }
\end{tabular}




\begin{tabular}{lccc} 
ativ_fis & 0,063 & 0,209 & 0,067 \\
bing & 0,167 & 0,049 & $-0,231$ \\
boate & 0,115 & 0,180 & $-0,080$ \\
camp_sol & 0,067 & 0,223 & $-0,013$ \\
cin & 0,119 & 0,198 & $-0,134$ \\
clube & $-0,011$ & 0,316 & $-0,087$ \\
conf1 & 0,019 & 0,239 & 0,087 \\
conf2 & 0,234 & $-0,095$ & 0,045 \\
conf3 & 0,196 & 0,034 & 0,000 \\
conf4 & 0,203 & 0,021 & $-0,011$ \\
conf5 & 0,223 & $-0,039$ & 0,031 \\
conf6 & 0,220 & $-0,034$ & 0,033 \\
conf7 & 0,225 & $-0,033$ & 0,007 \\
conf8 & 0,218 & $-0,027$ & 0,023 \\
conf9 & 0,214 & $-0,007$ & 0,007 \\
conf10 & 0,228 & $-0,075$ & 0,067 \\
doac & 0,195 & 0,037 & $-0,019$ \\
esport & 0,191 & 0,027 & $-0,061$ \\
Fest_com & 0,204 & 0,000 & $-0,015$ \\
igrej & 0,191 & $-0,046$ & 0,134 \\
Inst_car & 0,007 & 0,265 & 0,078 \\
Jog_mes & 0,195 & 0,009 & $-0,004$ \\
Mut & 0,095 & $-0,119$ & 0,325 \\
Ong & $-0,118$ & 0,328 & 0,092 \\
Out_com & 0,007 & 0,280 & $-0,084$ \\
Out_inst & $-0,117$ & 0,303 & 0,343 \\
praia & 0,168 & 0,111 & $-0,098$ \\
shopp & 0,189 & 0,069 & $-0,072$ \\
show & 0,068 & 0,229 & $-0,033$ \\
Sind & 0,097 & 0,146 & $-0,044$ \\
\hline Variância explicada & $54,34 \%$ & $22,41 \%$ & $4,54 \%$ \\
\hline & & &
\end{tabular}




\begin{tabular}{lrrrrr}
\hline \multicolumn{6}{c}{ Tabela 13: estatísticas descritivas das variáveis criminais } \\
\hline Variável & Obs & \multicolumn{1}{c}{ Média } & \multicolumn{1}{c}{ DP } & Min & \multicolumn{1}{c}{ Max } \\
hom_dol & 279 & 50,86 & 47,69 & 0 & 246 \\
oco_pol & 279 & 7596,98 & 3091,93 & 3198 & 18478 \\
inq_inst & 279 & 811,90 & 367,19 & 300 & 3292 \\
roub & 279 & 1294,67 & 621,95 & 416 & 3929 \\
roub_vei & 279 & 493,36 & 323,23 & 71 & 1898 \\
latr & 279 & 2,31 & 2,07 & 0 & 11 \\
seq & 279 & 1,54 & 1,84 & 0 & 12 \\
furt & 279 & 1034,80 & 806,84 & 226 & 5344 \\
furt_vei & 279 & 567,87 & 413,50 & 58 & 2143 \\
traf_mac & 279 & 10,86 & 8,23 & 0 & 52 \\
traf_coc & 279 & 9,78 & 10,43 & 0 & 81 \\
arm_fog & 279 & 45,46 & 23,31 & 2 & 143 \\
\hline
\end{tabular}

\begin{tabular}{lcrrrr}
\hline \multicolumn{5}{l}{ Tabela 14: estatísticas descritivas das variáveis ecológicas } \\
Variável & Obs & \multicolumn{1}{c}{ Média } & \multicolumn{1}{c}{ DP } & Min & Max \\
\hline ajud_esp & 93 & 15,16 & 10,55 & 0 & 46 \\
ajud_rec & 93 & 26,32 & 15,18 & 0 & 67 \\
ajud_solic & 93 & 2,60 & 2,30 & 0 & 11 \\
art & 93 & 19,17 & 10,07 & 0 & 46 \\
ass_com & 93 & 13,11 & 7,39 & 0 & 32 \\
ass_mor & 93 & 28,58 & 13,59 & 0 & 62 \\
atent_com & 93 & 16,16 & 9,00 & 0 & 39 \\
ativ_camp & 93 & 37,94 & 17,55 & 0 & 80 \\
ativ_com & 93 & 15,86 & 8,22 & 0 & 38 \\
ativ_esp & 93 & 17,90 & 9,16 & 0 & 40 \\
ativ_fis & 93 & 13,75 & 7,89 & 0 & 34 \\
bing & 93 & 10,80 & 6,98 & 0 & 34 \\
boate & 93 & 17,01 & 8,91 & 0 & 35 \\
camp_sol & 93 & 12,59 & 6,71 & 0 & 29 \\
cin & 93 & 4,72 & 3,12 & 0 & 14 \\
clube & 93 & 6,35 & 4,78 & 0 & 19 \\
conf1 & 93 & 14,32 & 8,11 & 0 & 37 \\
\hline & & $\mathrm{Con}$ & \\
\hline
\end{tabular}




\begin{tabular}{lrrrrr} 
conf10 & 93 & 5,89 & 3,74 & 0 & 15 \\
conf2 & 93 & 33,57 & 16,51 & 0 & 76 \\
conf3 & 93 & 231,98 & 109,62 & 0 & 596 \\
conf4 & 93 & 288,83 & 137,56 & 0 & 668 \\
conf5 & 93 & 202,76 & 96,47 & 0 & 493 \\
conf6 & 93 & 166,57 & 81,02 & 0 & 415 \\
conf7 & 93 & 181,72 & 85,89 & 0 & 448 \\
conf8 & 93 & 121,16 & 58,78 & 0 & 297 \\
conf9 & 93 & 113,70 & 53,87 & 0 & 267 \\
doac & 93 & 117,01 & 59,88 & 0 & 303 \\
esport & 93 & 39,71 & 18,45 & 0 & 88 \\
fest_com & 93 & 7,13 & 4,84 & 0 & 20 \\
igrej & 93 & 1,04 & 1,36 & 0 & 5 \\
inst_car & 93 & 1,72 & 1,72 & 0 & 8 \\
jog_mes & 93 & 13,35 & 6,73 & 0 & 29 \\
mut & 93 & 15,90 & 8,43 & 0 & 41 \\
ong & 93 & 9,33 & 5,70 & 0 & 26 \\
out_com & 93 & 6,39 & 4,05 & 0 & 19 \\
out_inst & 93 & 11,43 & 6,43 & 0 & 27 \\
praia & 93 & 1,89 & 2,01 & 0 & 10 \\
shopp & 93 & 1,62 & 1,37 & 0 & 6 \\
show & 93 & 3,31 & 2,69 & 0 & 12 \\
sind & 93 & 5,74 & 3,75 & 0 & 17 \\
\hline & & & & &
\end{tabular}




\begin{tabular}{lrrrrr}
\hline \multicolumn{6}{l}{ Tabela 15: estatísticas descritivas das variáveis ecológicas } \\
\hline Variável & Obs & \multicolumn{1}{c}{ Média } & \multicolumn{1}{c}{ DP } & \multicolumn{1}{c}{ Min } & \multicolumn{1}{c}{ Max } \\
\hline fav & 93 & 0,35 & 0,49 & 0,00 & 2,73 \\
fav_area & 93 & 0,03 & 0,03 & 0,00 & 0,13 \\
rend & 93 & 24,39 & 15,34 & 2,67 & 68,6 \\
prop_jov_cid & 93 & 1,02 & 0,64 & 0,09 & 2,94 \\
cres_pop & 93 & $-0,12$ & 1,89 & $-3,40$ & 3,83 \\
prop_jov_dist & 93 & 8,90 & 1,20 & 6,68 & 10,90 \\
mae_adol & 93 & 5,84 & 2,25 & 2,13 & 12,42 \\
não_esc & 93 & 19,42 & 6,63 & 8,45 & 41,30 \\
dens_pop & 93 & 10707,03 & 4995,71 & 42,00 & 24304,00 \\
fecund & 93 & 0,36 & 0,09 & 0,00 & 0,57 \\
esc_incomp & 93 & 32,99 & 9,68 & 18,01 & 66,30 \\
fluxo & 93 & 0,36 & 0,09 & 0,00 & 0,57 \\
\hline
\end{tabular}




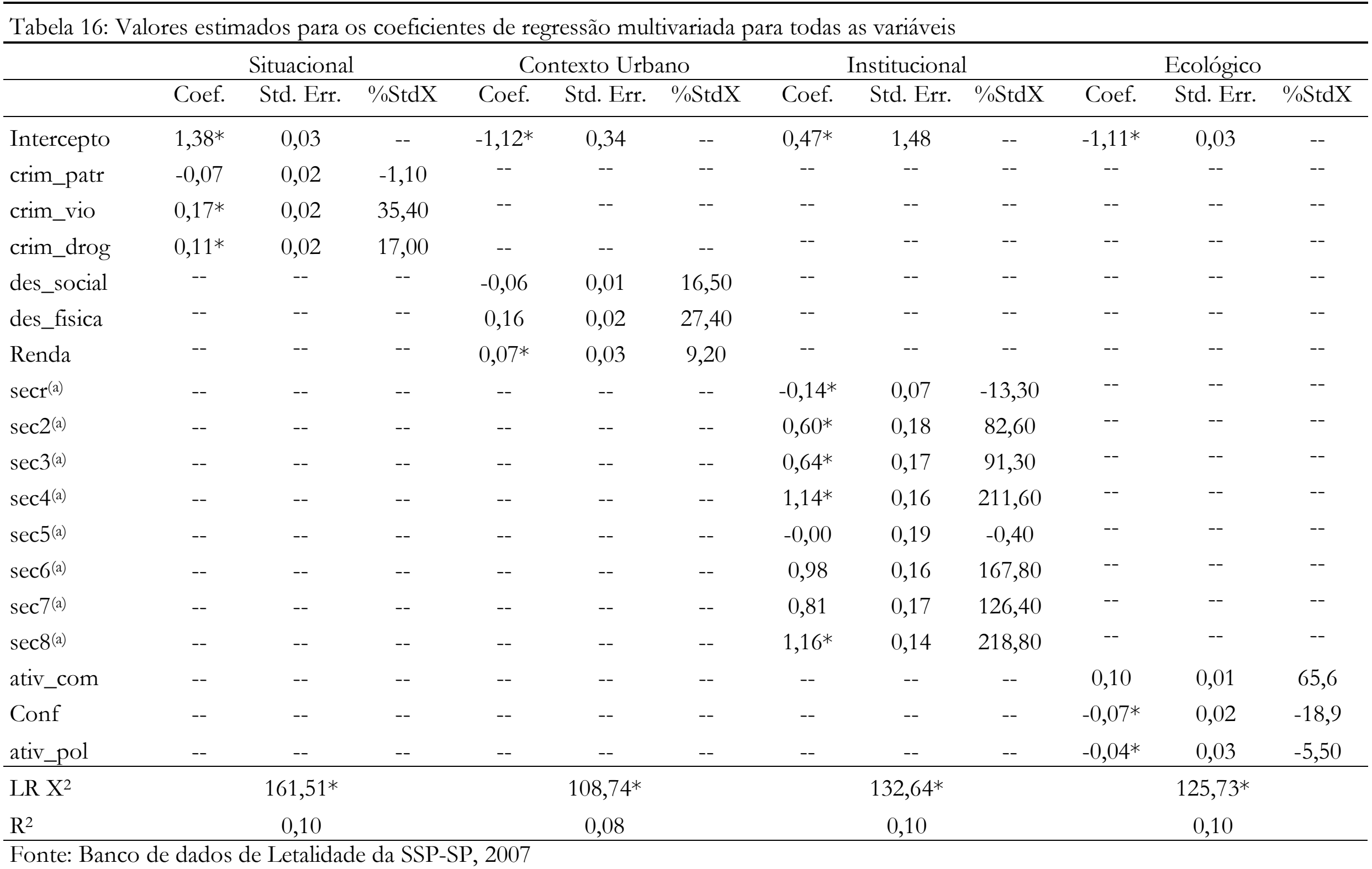




\begin{tabular}{|c|c|c|c|c|c|c|c|c|c|c|}
\hline \multicolumn{11}{|c|}{ Tabela 17: Correlações das variáveis para a amostra completa } \\
\hline & npol & crimpatr & crimvio & crimvei & crimdrog & des_social & des_fisica & renda & ativ_pol & conf \\
\hline npol & 1,00 & & & & & & & & & \\
\hline crimpatr & 0,04 & 1,00 & & & & & & & & \\
\hline crimvio & 0,36 & 0,14 & 1,00 & & & & & & & \\
\hline crimvei & 0,38 & 0,08 & 0,15 & 1,00 & & & & & & \\
\hline crimdrog & 0,25 & 0,15 & 0,00 & 0,05 & 1,00 & & & & & \\
\hline des_social & 0,29 & $-0,26$ & 0,06 & 0,30 & 0,07 & 1,00 & & & & \\
\hline des_fisica & 0,39 & $-0,29$ & 0,39 & 0,49 & 0,11 & 0,31 & 1,00 & & & \\
\hline enda & 0,05 & 0,11 & $-0,04$ & $-0,17$ & $-0,01$ & $-0,03$ & $-0,16$ & 1,00 & & \\
\hline ativ_pol & 0,15 & 0,49 & 0,26 & 0,03 & 0,14 & $-0,19$ & $-0,15$ & 0,17 & 1,00 & \\
\hline conf & 0,42 & 0,19 & 0,43 & 0,36 & 0,24 & 0,21 & 0,35 & 0,00 & 0,69 & 1,00 \\
\hline ativ_com & 0,25 & 0,04 & 0,26 & 0,39 & 0,16 & 0,25 & 0,37 & $-0,24$ & 0,42 & 0,65 \\
\hline
\end{tabular}


Mapa 1: distribuição espacial das mortes de não-policias em 2001

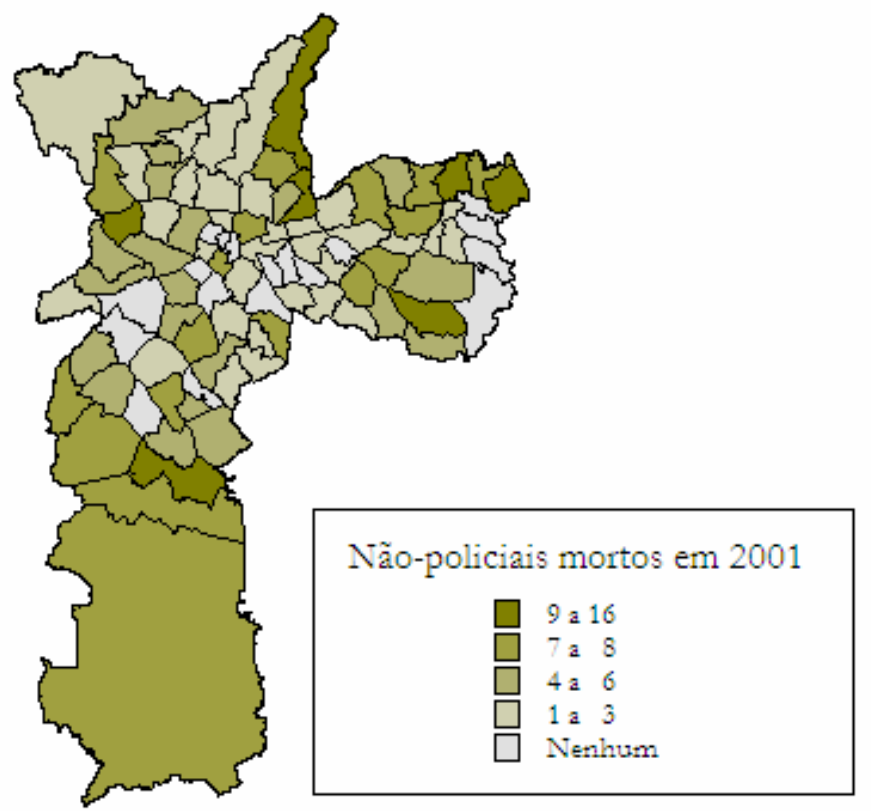

Fonte: Banco de Dados da Comissão de Letalidade da Secretaria de Segurança Pública de São Paulo

Mapa 2: distribuição espacial das mortes de não-policias em 2002

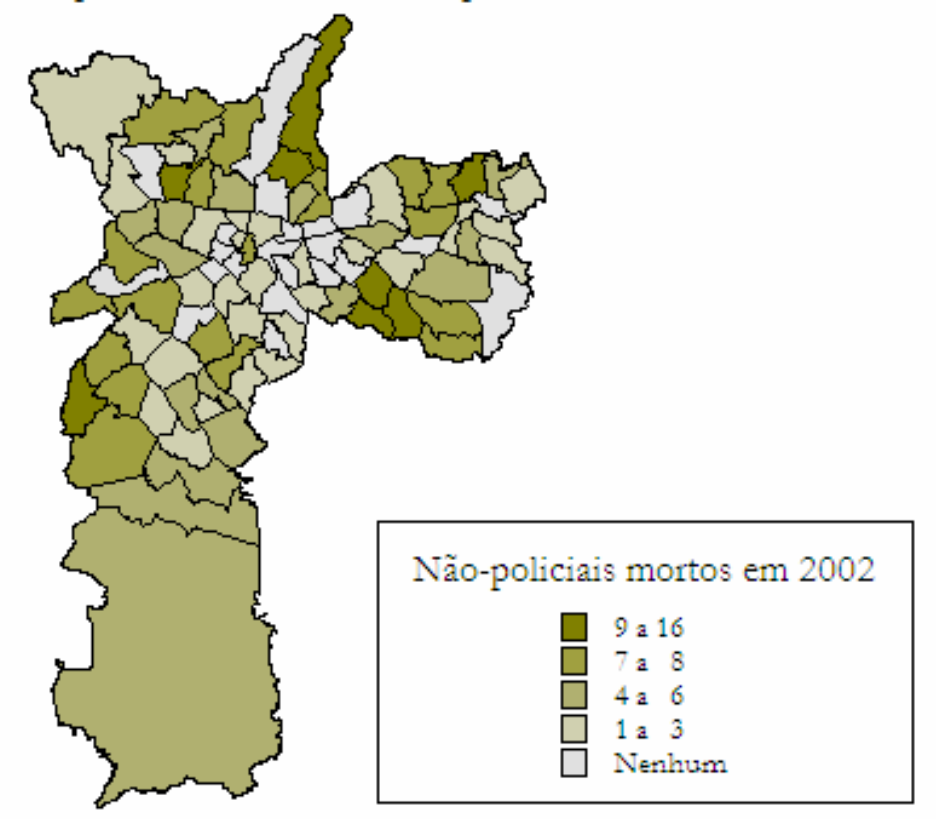

Fonte: Banco de Dados da Comissão de Letalidade da Secretaria de Segurança Pública de São Paulo 
Mapa 3: distribuição espacial das mortes de não-policias em 2003

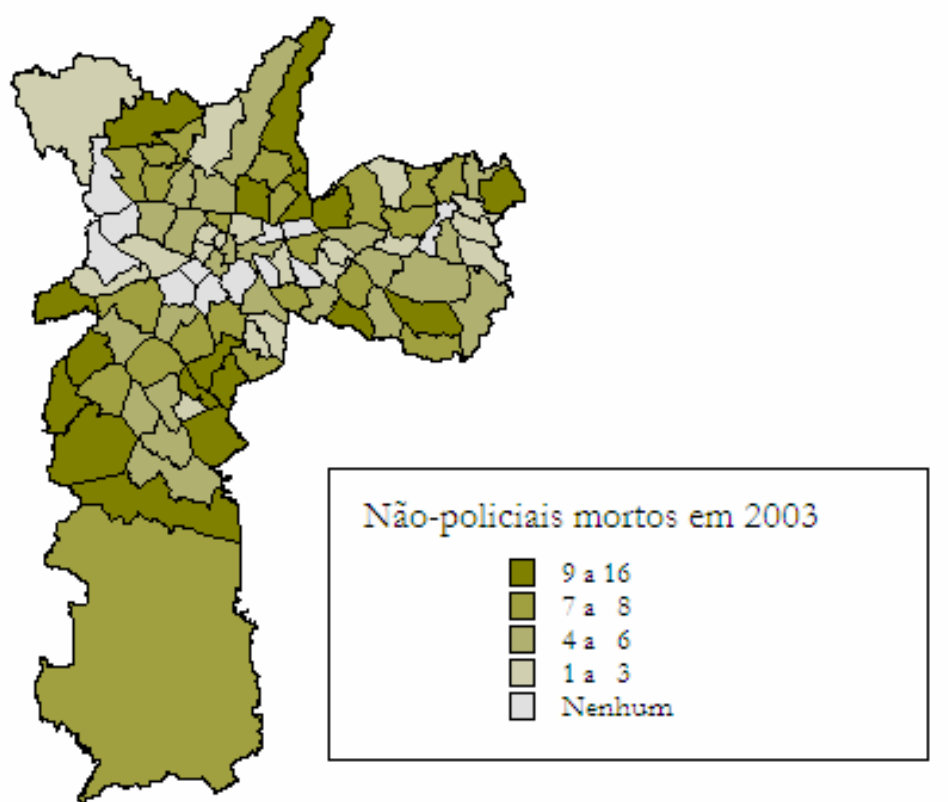

Fonte: Banco de Dados da Comissão de Letalidade da Secretaria de Segurança Pública de São Paulo

Mapa 4: distribuição espacial do Comando Territorial da Polícia de São Paulo

Fonte: Secretaria de Segurança Pública de São Paulo

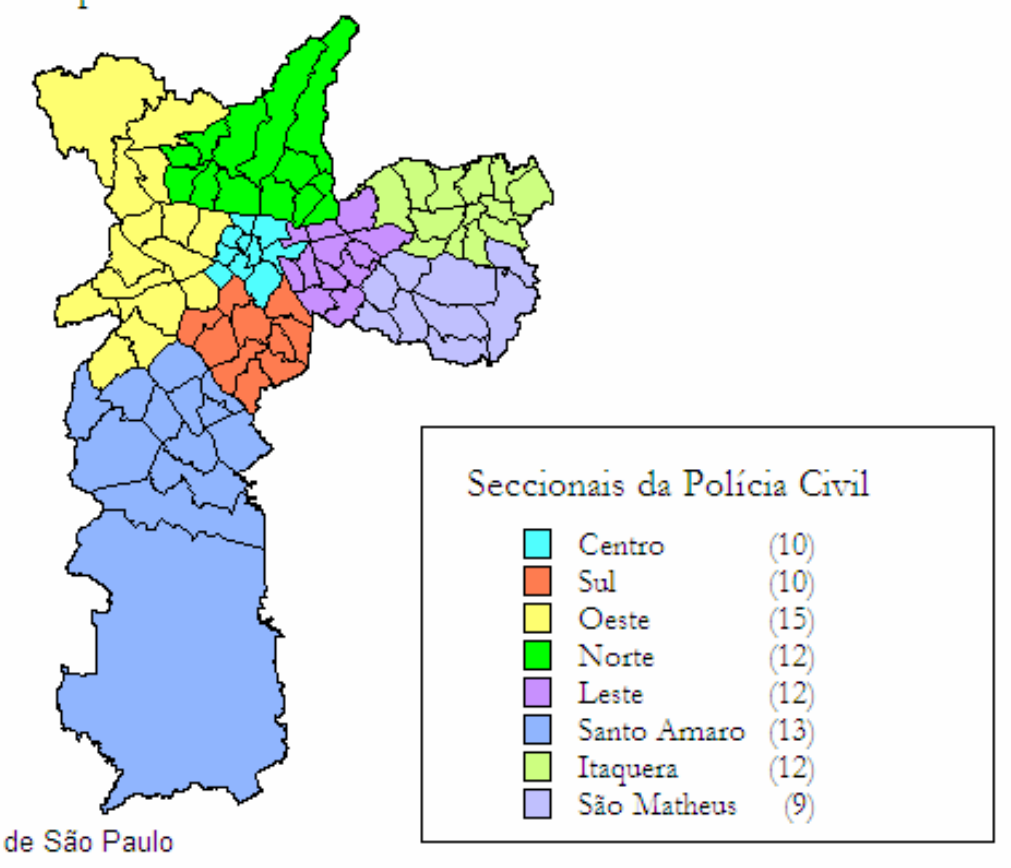


Mapa 5: distribuição espacial dos distritos da Polícia de São Paulo

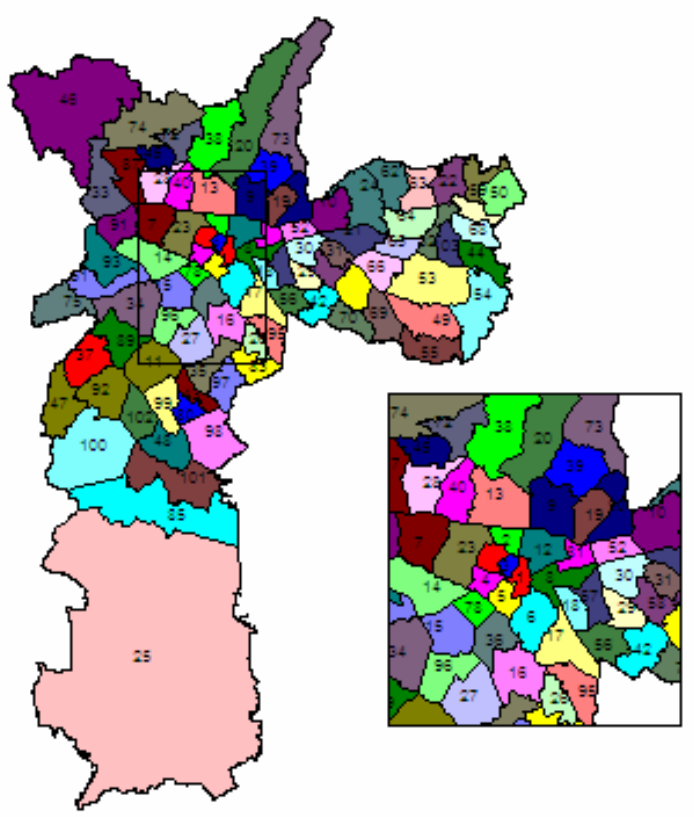

Fonte: Secretaria de Segurança Pública de São Paulo 


\begin{tabular}{|c|c|c|c|c|c|c|c|c|}
\hline ID & Seccional & Nome Sec. & Nome & 2001 & 2002 & 2003 & Média & DP \\
\hline $1^{\circ} \mathrm{DP}$ & 1 & Centro & Sé & 2 & 9 & 4 & 5,0 & 3,61 \\
\hline $2^{\circ} \mathrm{DP}$ & 1 & Centro & Bom Retiro & 1 & 3 & 8 & 4,0 & 3,61 \\
\hline $3^{\circ} \mathrm{DP}$ & 1 & Centro & Campos Elíseos & 1 & 1 & 2 & 1,3 & 0,58 \\
\hline $4^{\circ} \mathrm{DP}$ & 1 & Centro & Consolação & 1 & 10 & 2 & 4,3 & 4,93 \\
\hline $5^{\circ} \mathrm{DP}$ & 1 & Centro & Aclimação & 11 & 0 & 4 & 5,0 & 5,57 \\
\hline $6^{\circ} \mathrm{DP}$ & 1 & Centro & Cambuci & 1 & 3 & 5 & 3,0 & 2,00 \\
\hline $7^{\circ} \mathrm{DP}$ & 3 & Oeste & Lapa & 3 & 3 & 4 & 3,3 & 0,58 \\
\hline $8^{\circ} \mathrm{DP}$ & 1 & Centro & Brás & 1 & 1 & 4 & 2,0 & 1,73 \\
\hline $9^{\circ} \mathrm{DP}$ & 4 & Norte & Carandiru & 2 & 2 & 12 & 5,3 & 5,77 \\
\hline $10^{\circ} \mathrm{DP}$ & 5 & Leste & Penha de Franca & 3 & 1 & 8 & 4,0 & 3,61 \\
\hline $11^{\circ} \mathrm{DP}$ & 6 & Santo Amaro & Santo Amaro & 2 & 1 & 2 & 1,7 & 0,58 \\
\hline $12^{\circ} \mathrm{DP}$ & 1 & Centro & Pari & 5 & 2 & 1 & 2,7 & 2,08 \\
\hline $13^{\circ} \mathrm{DP}$ & 4 & Norte & Casa Verde & 2 & 4 & 5 & 3,7 & 1,53 \\
\hline $14^{\circ} \mathrm{DP}$ & 3 & Oeste & Pinheiros & 4 & 3 & 2 & 3,0 & 1,00 \\
\hline $15^{\circ} \mathrm{DP}$ & 3 & Oeste & Indianópolis & 4 & 2 & 0 & 2,0 & 2,00 \\
\hline $16^{\circ} \mathrm{DP}$ & 2 & Sul & Vila Clementino & 3 & 2 & 2 & 2,3 & 0,58 \\
\hline $17^{\circ} \mathrm{DP}$ & 2 & Sul & Ipiranga & 2 & 1 & 5 & 2,7 & 2,08 \\
\hline $18^{\circ} \mathrm{DP}$ & 5 & Leste & Alto da Mooca & 0 & 0 & 0 & 0,0 & 0,00 \\
\hline $19^{\circ} \mathrm{DP}$ & 4 & Norte & Vila Maria & 3 & 2 & 2 & 2,3 & 0,58 \\
\hline $20^{\circ} \mathrm{DP}$ & 4 & Norte & Água Fria & 1 & 2 & 5 & 2,7 & 2,08 \\
\hline $21^{\circ} \mathrm{DP}$ & 5 & Leste & Vila Matilde & 2 & 4 & 5 & 3,7 & 1,53 \\
\hline $22^{\circ} \mathrm{DP}$ & 7 & Itaquera & São Miguel Paulista & 11 & 11 & 8 & 10,0 & 1,73 \\
\hline $23^{\circ} \mathrm{DP}$ & 3 & Oeste & Perdizes & 5 & 1 & 5 & 3,7 & 2,31 \\
\hline $24^{\circ} \mathrm{DP}$ & 7 & Itaquera & Erm. Matarazzo & 5 & 3 & 6 & 4,7 & 1,53 \\
\hline $25^{\circ} \mathrm{DP}$ & 6 & Santo Amaro & Parelheiros & 5 & 4 & 7 & 5,3 & 1,53 \\
\hline $26^{\circ} \mathrm{DP}$ & 2 & Sul & Sacomã & 4 & 0 & 2 & 2,0 & 2,00 \\
\hline $27^{\circ} \mathrm{DP}$ & 2 & Sul & Ibirapuera & 6 & 8 & 6 & 6,7 & 1,15 \\
\hline $28^{\circ} \mathrm{DP}$ & 4 & Norte & Freguesia de Ó & 3 & 11 & 6 & 6,7 & 4,04 \\
\hline $29^{\circ} \mathrm{DP}$ & 5 & Leste & Vila Prudente & 1 & 1 & 0 & 0,7 & 0,58 \\
\hline $30^{\circ} \mathrm{DP}$ & 5 & Leste & Tatuapé & 2 & 0 & 5 & 2,3 & 2,52 \\
\hline $31^{\circ} \mathrm{DP}$ & 5 & Leste & Vila Carrão & 0 & 2 & 1 & 1,0 & 1,00 \\
\hline $32^{\circ} \mathrm{DP}$ & 7 & Itaquera & Itaquera & 1 & 4 & 0 & 1,7 & 2,08 \\
\hline $33^{\circ} \mathrm{DP}$ & 3 & Oeste & Pirituba & 7 & 1 & 0 & 2,7 & 3,79 \\
\hline $34^{\circ} \mathrm{DP}$ & 3 & Oeste & Morumbi & 0 & 6 & 6 & 4,0 & 3,46 \\
\hline $35^{\circ} \mathrm{DP}$ & 2 & Sul & Jabaquara & 5 & 6 & 10 & 7,0 & 2,65 \\
\hline $36^{\circ} \mathrm{DP}$ & 2 & Sul & Vila Mariana & 0 & 0 & 0 & 0,0 & 0,00 \\
\hline $37^{\circ} \mathrm{DP}$ & 3 & Oeste & Campo Limpo & 5 & 3 & 11 & 6,3 & 4,16 \\
\hline $38^{\circ} \mathrm{DP}$ & 4 & Norte & Vila Amália & 1 & 8 & 2 & 3,7 & 3,79 \\
\hline $39^{\circ} \mathrm{DP}$ & 4 & Norte & Vila Gustavo & 6 & 9 & 8 & 7,7 & 1,53 \\
\hline $40^{\circ} \mathrm{DP}$ & 4 & Norte & Vila Santa Maria & 1 & 6 & 6 & 4,3 & 2,89 \\
\hline
\end{tabular}




\begin{tabular}{|c|c|c|c|c|c|c|c|c|}
\hline $41^{\circ} \mathrm{DP}$ & 8 & São Mateus & Vila Rica & 6 & 12 & 8 & 8,7 & 3,06 \\
\hline $42^{\circ} \mathrm{DP}$ & 5 & Leste & Parq. São Lucas & 1 & 4 & 6 & 3,7 & 2,52 \\
\hline $43^{\circ} \mathrm{DP}$ & 6 & Santo Amaro & Cidade Ademar & 2 & 6 & 10 & 6,0 & 4,00 \\
\hline $44^{\circ} \mathrm{DP}$ & 8 & São Mateus & Guaianazes & 1 & 2 & 1 & 1,3 & 0,58 \\
\hline $45^{\circ} \mathrm{DP}$ & 4 & Norte & Vila Brasilândia & 4 & 3 & 10 & 5,7 & 3,79 \\
\hline $46^{\circ} \mathrm{DP}$ & 3 & Oeste & Perus & 1 & 2 & 1 & 1,3 & 0,58 \\
\hline $47^{\circ} \mathrm{DP}$ & 6 & Santo Amaro & Capão Redondo & 5 & 10 & 12 & 9,0 & 3,61 \\
\hline $48^{\circ} \mathrm{DP}$ & 6 & Santo Amaro & Cidade Dutra & 4 & 1 & 4 & 3,0 & 1,73 \\
\hline $49^{\circ} \mathrm{DP}$ & 8 & São Mateus & São Matheus & 9 & 7 & 12 & 9,3 & 2,52 \\
\hline $50^{\circ} \mathrm{DP}$ & 7 & Itaquera & Itaim Paulista & 8 & 4 & 11 & 7,7 & 3,51 \\
\hline $51^{\circ} \mathrm{DP}$ & 3 & Oeste & Rio Pequeno & 3 & 3 & 4 & 3,3 & 0,58 \\
\hline $52^{\circ} \mathrm{DP}$ & 5 & Leste & Parq. São Jorge & 1 & 0 & 0 & 0,3 & 0,58 \\
\hline $53^{\circ} \mathrm{DP}$ & 8 & São Mateus & Parque do Carmo & 6 & 4 & 5 & 5,0 & 1,00 \\
\hline $54^{\circ} \mathrm{DP}$ & 8 & São Mateus & Cid. Tiradentes & 0 & 0 & 0 & 0,0 & 0,00 \\
\hline $55^{\circ} \mathrm{DP}$ & 8 & São Mateus & Parq. São Rafael & 5 & 10 & 4 & 6,3 & 3,21 \\
\hline $56^{\circ} \mathrm{DP}$ & 5 & Leste & Vila Alpina & 2 & 2 & 7 & 3,7 & 2,89 \\
\hline $57^{\circ} \mathrm{DP}$ & 5 & Leste & Parque da Mooca & 2 & 1 & 6 & 3,0 & 2,65 \\
\hline $58^{\circ} \mathrm{DP}$ & 5 & Leste & Vila Formosa & 1 & 1 & 2 & 1,3 & 0,58 \\
\hline $59^{\circ} \mathrm{DP}$ & 7 & Itaquera & Jardim dos Ipês & 6 & 5 & 2 & 4,3 & 2,08 \\
\hline $62^{\circ} \mathrm{DP}$ & 7 & Itaquera & Jardim Popular & 2 & 6 & 4 & 4,0 & 2,00 \\
\hline $63^{\circ} \mathrm{DP}$ & 7 & Itaquera & Vila Jacui & 7 & 12 & 7 & 8,7 & 2,89 \\
\hline $64^{\circ} \mathrm{DP}$ & 7 & Itaquera & Cid. A.E. Carval. & 7 & 7 & 7 & 7,0 & 0,00 \\
\hline $65^{\circ} \mathrm{DP}$ & 7 & Itaquera & Artur Alvim & 2 & 1 & 2 & 1,7 & 0,58 \\
\hline $66^{\circ} \mathrm{DP}$ & 8 & São Mateus & Jard. Aricanduva & 7 & 4 & 4 & 5,0 & 1,73 \\
\hline $67^{\circ} \mathrm{DP}$ & 7 & Itaquera & Jardim Robru & 0 & 0 & 2 & 0,7 & 1,15 \\
\hline $68^{\circ} \mathrm{DP}$ & 7 & Itaquera & Lajeado & 0 & 2 & 2 & 1,3 & 1,15 \\
\hline $69^{\circ} \mathrm{DP}$ & 8 & São Mateus & Teotônio Vilela & 5 & 12 & 5 & 7,3 & 4,04 \\
\hline $70^{\circ} \mathrm{DP}$ & 8 & São Mateus & Vila Ema & 2 & 10 & 14 & 8,7 & 6,11 \\
\hline $72^{\circ} \mathrm{DP}$ & 4 & Norte & Vl Penteado & 4 & 4 & 8 & 5,3 & 2,31 \\
\hline $73^{\circ} \mathrm{DP}$ & 4 & Norte & Jaçanã & 15 & 14 & 16 & 15,0 & 1,00 \\
\hline $74^{\circ} \mathrm{DP}$ & 3 & Oeste & Parada Taipas & 4 & 7 & 12 & 7,7 & 4,04 \\
\hline $75^{\circ} \mathrm{DP}$ & 3 & Oeste & Jardim Arpoador & 1 & 6 & 10 & 5,7 & 4,51 \\
\hline $77^{\circ} \mathrm{DP}$ & 1 & Centro & Santa Cecília & 0 & 0 & 2 & 0,7 & 1,15 \\
\hline $78^{\circ} \mathrm{DP}$ & 1 & Centro & Jardins & 0 & 0 & 0 & 0,0 & 0,00 \\
\hline $80^{\circ} \mathrm{DP}$ & 6 & Santo Amaro & Vila Joaniza & 5 & 1 & 2 & 2,7 & 2,08 \\
\hline $81^{\circ} \mathrm{DP}$ & 5 & Leste & Belém & 2 & 0 & 0 & 0,7 & 1,15 \\
\hline $83^{\circ} \mathrm{DP}$ & 2 & Sul & Parque Bristol & 2 & 3 & 6 & 3,7 & 2,08 \\
\hline $85^{\circ} \mathrm{DP}$ & 6 & Santo Amaro & Jardim Mirna & 8 & 4 & 10 & 7,3 & 3,06 \\
\hline $87^{\circ} \mathrm{DP}$ & 3 & Oeste & Pereira Barreto & 4 & 1 & 7 & 4,0 & 3,00 \\
\hline $89^{\circ} \mathrm{DP}$ & 3 & Oeste & Jardim Tamaio & 1 & 4 & 5 & 3,3 & 2,08 \\
\hline $90^{\circ} \mathrm{DP}$ & 4 & Norte & Parq Nov. Mundo & 9 & 6 & 11 & 8,7 & 2,52 \\
\hline $91^{\circ} \mathrm{DP}$ & 3 & Oeste & Ceasa & 3 & 3 & 0 & 2,0 & 1,73 \\
\hline $92^{\circ} \mathrm{DP}$ & 6 & Santo Amaro & Parq. Sto. Antonio & 4 & 7 & 8 & 6,3 & 2,08 \\
\hline
\end{tabular}




\begin{tabular}{lllllllll}
\hline $93^{\circ} \mathrm{DP}$ & 3 & Oeste & Jaguaré & 3 & 8 & 0 & 3,7 & 4,04 \\
$95^{\circ} \mathrm{DP}$ & 2 & Sul & Heliópolis & 6 & 1 & 1 & 2,7 & 2,89 \\
$96^{\circ} \mathrm{DP}$ & 2 & Sul & Monções & 3 & 1 & 5 & 3,0 & 2,00 \\
$97^{\circ} \mathrm{DP}$ & 2 & Sul & Americanópolis & 1 & 0 & 8 & 3,0 & 4,36 \\
$98^{\circ} \mathrm{DP}$ & 6 & Santo Amaro & Jardim Míriam & 4 & 4 & 11 & 6,3 & 4,04 \\
$99^{\circ} \mathrm{DP}$ & 6 & Santo Amaro & Campo Grande & 8 & 5 & 4 & 5,7 & 2,08 \\
$100^{\circ} \mathrm{DP}$ & 6 & Santo Amaro & Jardim Herculano & 9 & 9 & 12 & 10,0 & 1,73 \\
$101^{\circ} \mathrm{DP}$ & 6 & Santo Amaro & Jardim Imbuias & 15 & 5 & 4 & 8,0 & 6,08 \\
$102^{\circ} \mathrm{DP}$ & 6 & Santo Amaro & Socorro & 0 & 1 & 5 & 2,0 & 2,65 \\
$103^{\circ} \mathrm{DP}$ & 7 & Itaquera & Coahab II - & 2 & 4 & 4 & 3,3 & 1,15 \\
\hline
\end{tabular}

